UNIVERSIDADE DE BRASÍLIA

INSTITUTO DE CIÊNCIAS HUMANAS

DEPARTAMENTO DE HISTÓRIA

PROGRAMA DE PÓS-GRADUAÇÃO EM HISTÓRIA

PEDRO HENRIQUE SOARES SANTOS

Recrutamento, castigo e direitos do cidadão no Exército do Primeiro Reinado 
PEDRO HENRIQUE SOARES SANTOS

\section{Recrutamento, castigo e direitos do cidadão no Exército do Primeiro Reinado}

Dissertação apresentada ao Programa de Pós-Graduação em História da Universidade de Brasília (UnB), como requisito para a obtenção do título de mestre em História. Linha de Pesquisa: Poder, instituições e sociedade.

Orientadora: Dra. Neuma Brilhante Rodrigues. 
PEDRO HENRIQUE SOARES SANTOS

\section{Recrutamento, castigo e direitos do cidadão no Exército do Primeiro Reinado}

Dissertação de mestrado submetida ao Programa de Pós-Graduação em História da Universidade de Brasília (UnB), como parte dos requisitos necessários à obtenção do título de mestre em História.

BANCA EXAMINADORA

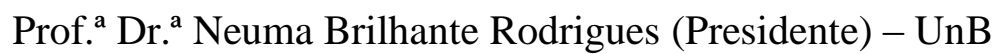

Prof. ${ }^{a}$ Dr. ${ }^{a}$ Tereza Cristina Kirschner - (Avaliadora) - UnB

Prof. Dr. Cristiano Otavio Paixão Araujo Pinto (Avaliador) - UnB

Prof. Dr. Francisco Fernando Monteoliva Doratioto (Suplente) - UnB 
Ao Deus Pai.

À Minha Família.

Ao meu padrinho, Seu Chico, in memoriam. 


\section{Agradecimentos}

Parte mais gratificante de todo trabalho, os agradecimentos são espaço propício para expressar o profundo reconhecimento e gratidão pelo apoio que recebi nestes longos dois anos de pesquisa e escrita.

Em primícias, agradecer ao Deus Pai criador de todas as coisas visíveis e invisíveis; a Seu Filho Salvador (Deum de Deo, lumen de lumine, Deum verum de Deo vero, Genitum, non factum, consubstantialem Patri: Per quem omnia facta sunt); ao Espírito Paráclito. À intercessão da Virgem Santíssima, de S. Bento de Núrcia, de S. Judas Tadeu e à toda a multidão de anjos e santos que não cessaram de pedir junto ao Pai por mim. À Igreja Una, Santa, Católica e Apostólica, que, distribuindo validamente os sacramentos, deu-me acesso à Graça divina.

Devo muitos agradecimentos à minha família, meu sustentáculo durante este período. Devo agradecer especialmente minha mãe que sofreu junto comigo nesta caminhada e muito me ajudou nos momentos mais difíceis. Também meu pai, que com sobriedade me aconselhou durante este período. Aos meus tios e tias, em particular minhas tias Maria Leovalda, Ilda e Elma e meu tio José Eustáquio, e aos meus avós, Ester e Edgar, que me acompanharam e auxiliaram nesta jornada. A todos, meu muito obrigado.

Muita gratidão também é devida à minha querida namorada Renata e aos meus amigos que, tornando a vida mais leve e tranquila, diminuíram o fardo e o cansaço da jornada. Um abraço especial ao Guilherme, ao Henrique, ao Danilo, ao Diego, ao Diogo, à Natália, ao Jorge, ao Bruno, ao Vitor, ao Adrian, ao Felipe, à Karina, à Moro, à Carol, ao André, à Cibele, ao Gustavo, ao Rodrigo Piubelli, ao Pe. Fernando, ao Molinari.

Agradeço muitíssimo à minha orientadora, Neuma Brilhante, que com muita paciência, guiou-me, auxiliou-me, corrigiu-me e aconselhou-me durante este percurso. Sem seu apoio, esta tarefa teria sido muito mais difícil, quiçá impossível. Considero-me um estudante de muita sorte por tê-la como mestra.

Também gostaria de expressar minha gratidão aos professores Tereza C. Kirschner e Francisco Doratioto pela formação intelectual e cidadã que me forneceram ao longo de minha vida acadêmica. 
Por fim, agradeço à Universidade de Brasília e à Coordenação de Aperfeiçoamento de Pessoal de Nível Superior (CAPES) pelo apoio institucional e pela bolsa de estudos. 


\title{
Recrutamento, castigo e direitos do cidadão no Exército \\ do Primeiro Reinado
}

\begin{abstract}
RESUMO
Esta dissertação busca compreender a readequação do Exército imperial num contexto em que o Estado brasileiro se fundava sob bases constitucionais. Foram analisados dois aspectos centrais à instituição e que envolviam diretamente o governo e a população: o recrutamento e os castigos. Para alcançar esse objetivo, examinaram-se as normas militares herdadas do período colonial e outras editadas pelo governo de d. Pedro I. Também foram apreciados os Anais da Câmara dos Deputados durante a primeira legislatura, particularmente os debates legislativos sobre esses objetos. A partir da pesquisa feita, foi possível perceber uma preocupação tanto do Executivo quanto do Legislativo em repensar a instituição militar neste período de modo a garantir as liberdades individuais dos cidadãos marcadas na Carta Magna de 1824.
\end{abstract}

Palavras-chave: Direitos do cidadão; recrutamento; castigos no Exército. 


\title{
Recruitment, punishment and citizens' rights in the Brazilian Imperial Army
}

\begin{abstract}
This dissertation seeks to comprehend the readaptation of the Imperial Army at the moment in which the Brazilian State was founded on a constitutional basis. There were analyzed two central aspects of this institution that directly put the government in contact and conflict with the governed population: the recruitment and the punishments in the army. In order to reach this objective, there were examined the military norms inherited from the colonial period and those edited by the government of d. Pedro I. There also analyzed the legislative debates about these themes occurred in the Chamber of Deputies during its first legislature. It is clear, as a conclusion, that the Executive and Legislative powers of the Imperial Brazil were preoccupied in rethinking the military institution during the reign of Pedro I in order to guarantee the individual liberties of the Brazilian citizens listed in the Constitution of 1824.
\end{abstract}

Key-words: Citizens' rights; recruitment; punishments in the Army. 


\section{SUMÁRIO}

Introdução

1. Legem habemus: o constitucionalismo, a Independência e a fundação do Brasil sob o império da lei ........................................................... 21

$1.1 \mathrm{Na}$ esteira do Constitucionalismo nasce um novo Estado .................................. 23

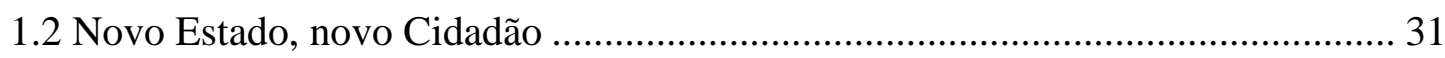

1.3 A um Estado Constitucional, um Direito Constitucional .................................... 42

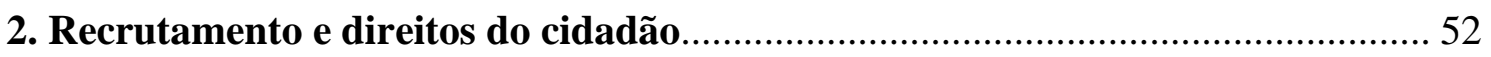

2.1 Uma breve introdução ao Exército do Primeiro Reinado ..................................... 54

2.1.1 A organização geral das forças imperiais ................................................... 54

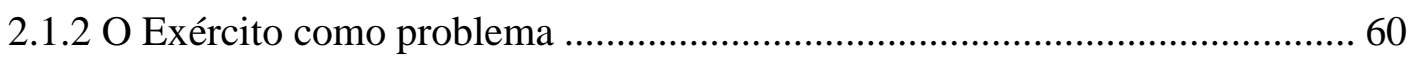

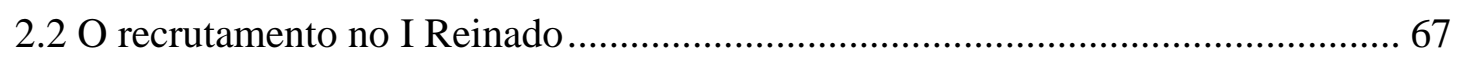

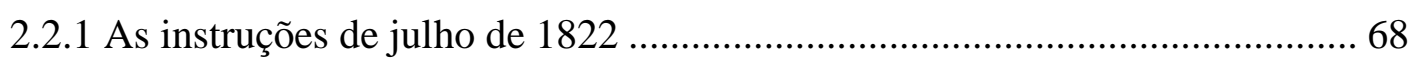

2.2.2 Dão-se homens como porcos: os casos do Ceará e de Minas Gerais .............. 83

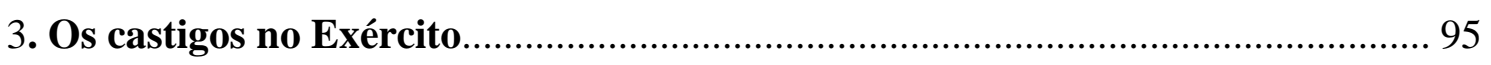

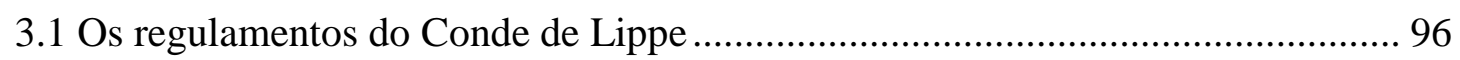

3.2 Entre as chibatas, os açoites e a Constituição ..................................................... 100

3.2.1 O Executivo, os castigos sumários e os perdões ........................................ 100

3.2.2 A Câmara debate os castigos .................................................................... 105

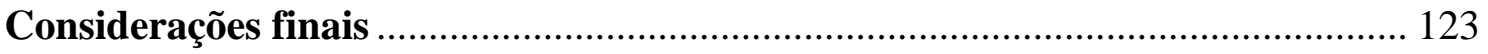

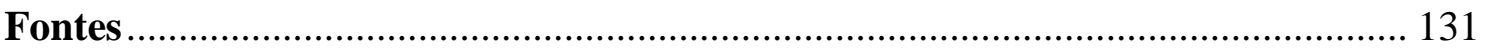

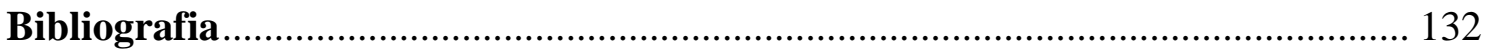




\section{Introdução}

O Exército brasileiro, pela importância que teve nos acontecimentos da história pátria, foi objeto de muitos estudos. Diversos militares e civis se debruçaram sobre a história da instituição de modo a entender sua formação, sua modernização, os momentos em que interferiu na vida política nacional, entre outros temas. Alguns períodos de sua história, no entanto, foram muito pouco estudados, relegados a segundo plano e a trabalhos de curiosos e especialistas militares.

Estranhamente, tal é o caso da história do Exército durante o reinado de d. Pedro I. Estranhamente porque o país realizou várias ações militares nesse período, enfrentando Portugal logo após a proclamação da independência, sufocando rebeliões internas - como a Confederação do Equador, de 1824 -, lutando pela manutenção da posse brasileira da Cisplatina (atual Uruguai) contra as Províncias Unidas do Rio da Prata (atual Argentina), entre tantos outros eventos.

Poucos foram os estudiosos que escreveram sobre tais assuntos, se se comparar com a produção acerca de outros temas e períodos. Em face desse quadro de pequena produção bibliográfica, curioso com esse período de formação do Estado brasileiro e incentivado por minha orientadora Neuma Brilhante, realizei algumas pesquisas na graduação sobre a Guerra da Cisplatina. Pesquisei sobre seus antecedentes e razões, as forças em contenda, o que estava em jogo, seu fim e suas consequências.

Nessa investigação tive contato com fontes políticas e militares brasileiras - em particular com cartas de líderes militares durante a campanha e com os Anais da Câmara dos Deputados - e com os problemas que as autoridades tiveram de enfrentar durante o esforço de guerra. Dentre esses, destacaram-se o problema de recrutar homens e de punir os desertores, cujo número havia aumentado significativamente desde o começo das atividades bélicas. Na leitura e análises dessas fontes, saltava aos olhos a 
preocupação dos deputados com os abusos ocorridos na prática do recrutamento e dos castigos. Expressavam desejo de coibi-los e de reformar o Exército de modo a "atualizálo" para entrar em consonância com as novas ideias e instituições constitucionais.

De modo a entender melhor a construção do Estado liberal ${ }^{1}$ e constitucional no Brasil e o porquê da grande preocupação desses homens com aquelas questões, passei a me dedicar aos estudos sobre a cidadania, o direito e a construção das instituições políticas nos primórdios do Império. Depois de ler algumas obras acerca do tema, das quais se tratará adiante, pude entender como os debates realizados pelos deputados e outros membros da classe política acerca das forças armadas estavam umbilicalmente ligados à discussão sobre a formação de um Estado fundado sobre o "Império das leis". Assim, decidi aprofundar-me no estudo de como os dois objetos - o Exército e os direitos do cidadão - se entrelaçavam no período.

Decidi pesquisar, então, a maneira como se relacionavam os direitos dos cidadãos inaugurados com o movimento constitucionalista da década de 1820 no mundo luso-brasileiro e as práticas de recrutamento e de castigo dentro da instituição do Exército durante o Primeiro Reinado (1822-1831). A escolha desses dois aspectos, o recrutamento e os castigos, é justificada na medida em que sua análise permite entrever pontos de tensão entre a atuação do Estado e as garantias individuais marcadas na Carta constitucional de 1824 .

O corte cronológico proposto para a dissertação abrange desde a promulgação das instruções de recrutamento editadas pelo príncipe Regente em julho de 1822 até a abdicação do Imperador em 1831, momento em que o Exército passou por mudanças em sua organização geral.

Para melhor compreender e situar o objeto de pesquisa colocado em questão, foi indispensável adentrar três campos historiográficos que conheceram grande expansão nos últimos anos: a historiografia militar do Brasil, aquela sobre o Primeiro Reinado e a

\footnotetext{
${ }^{1}$ Neste trabalho, utiliza-se o termo "liberal" aqueles que defendiam o conjunto de práticas políticas marcadas pela divisão dos poderes, representação política e garantia dos direitos individuais, particularmente os civis, tendo, portanto, quase a mesma acepção que o conceito de "constitucional" durante a década de 1820 no Brasil independente, ou seja, denotando aqueles contrários à monarquia absoluta. Slemian toma os termos por intercambiáveis. Cf. LOPES, "Iluminismo e jusnaturalismo no ideário dos juristas da primeira metade do século XIX", p. 198, nota 3, baseado em MATEUCCI, Nicola. Organización del poder y libertad: história del constitucionalismo moderno. Madri: Trotta, 1998; Cf. SLEMIAN, Andrea. Sob o Império das Leis. São Paulo: Hucitec, 2009, p. 37, nota 68, baseada em SEBASTIÁN, Javier Fernández. "Revolucionarios y liberales. Conceptos e identidades políticas en el mundo atlántico." IN CALDERÓN, Maria Teresa; THIBAUD, Clément (orgs.). Las revoluciones en el mundo atlántico. Colômbia: Universidad Externado-Taurus-Fundación Carolina, p. 215-250. Cf. NEVES, Lúcia Maria Bastos Pereira das. Corcundas e constitucionais. Rio de Janeiro: Revan: FAPERJ, 2003.
} 
sobre a cidadania no Império. Passemos então a um rápido apontamento desses campos historiográficos e os debates mais importantes para esta dissertação e, em seguida, para uma descrição e discussão das fontes utilizadas.

A historiografia militar do Brasil desde as primeiras décadas do século XX até por volta das décadas de 1980 e 1990 foi marcada por obras de grupos de militares que produziram trabalhos históricos voltados à descrição das guerras e batalhas mobilização de recursos, número de soldados dos exércitos em contenda, movimentação de tropas etc. - em que forças "brasileiras" tomaram parte desde o período colonial. ${ }^{2}$ Preocupavam-se com a análise da atuação dos comandantes à frente das tropas nas campanhas, valorando suas atitudes à luz da estratégia e táticas adotadas. ${ }^{3}$ Essa produção historiográfica não levantava como questões as relações entre as forças armadas e a população, os meios adotados para o recrutamento, as condições de vida dos soldados e oficiais, as origens sociais de ambos os grupos, o impacto social do serviço das armas como um todo e o valor que essa atividade possuía para aqueles que a praticavam.

Após a redemocratização do país em fins dos anos 1980, surgiu um interesse acadêmico maior, nacional e internacionalmente, pelo papel dos militares na vida política do Brasil. Vários estudos foram feitos sobre as forças armadas na história brasileira, enfocando, entre outros temas, as políticas "salvacionistas", as intervenções no período republicano, a formação intelectual do corpo de oficiais do Exército e da Marinha, e, por influência da história social, o relacionamento entre essas instituições e a sociedade de modo geral. Importantes personagens foram retomados, interpretados não mais sob o viés de heróis perfeitos, mas de homens singulares com suas trajetórias

\footnotetext{
${ }^{2}$ De modo geral, esta historiografia considerava que o processo de cesura entre metrópole e colônia era natural já que o sentimento nacional brasileiro se encontrava presente desde os primórdios da expansão portuguesa. Em outras palavras, partem de pressupostos teleológicos do período colonial, em que todas as províncias que constituíam a América portuguesa se dirigiriam, necessariamente, rumo à independência. Foi a partir dessa perspectiva que se tornou possível falar da fundação do "Exército brasileiro" em 1648 na batalha de Guararapes. Pode-se citar como exemplo dessa historiografia os trabalhos de: CARNEIRO, História da Guerra Cisplatina; FRAGOSO, A batalha do Passo do Rosário; WIERDESPAHN, Campanha de Ituzaingó.

${ }^{3}$ Exemplos dessa historiografia são:

CARNEIRO, David. História da Guerra Cisplatina. Brasília: Universidade de Brasília, 1983.

FRAGOSO, Tasso. A batalha do Passo do Rosário. Rio de Janeiro: Biblioteca do Exército Editora, 1951.

FRANCO, Afonso Arinos de Melo. Um Soldado do Reino e do Império. Rio de Janeiro: Biblioteca do Exército Editora, 1942.

SANTOS, Amilcar Salgado dos. A Guerra entre o Brasil e a República Argentina em 1827. São Paulo: Escolas Profissionaes do Lyceu Coração de Jesus, 1923.

WIERDESPAHN, Oscar. Campanha de Ituzaingó. Rio de Janeiro: Biblioteca do Exército Editora, 1961.
} 
específicas, seus relacionamentos, suas falhas. Também se tomou como objeto os rituais, símbolos e tradições das forças armadas ao longo do tempo. Por fim, sob a ótica da história social e da chamada nova história política, foram revistas as guerras em que o Brasil se envolveu, particularmente a Guerra do Paraguai. ${ }^{4}$

Os trabalhos mais importantes dessa área para esta dissertação, e que se encaixam no movimento historiográfico sumariamente descrito acima, são os de Adriana Barreto de Souza, de Fábio Mendes e de Michael Charles McBeth. ${ }^{5}$ Os três autores retrataram, com enfoques diferentes, os temas da formação dos oficias, sua origem social, suas relações com a política, a maneira como era feito o recrutamento e a distribuição não-universal deste, a relação entre a oficialidade e os praças e o tipo de disciplina exigida destes por aqueles, o caráter diletante do serviço miliciano, a utilização de formas administrativas indiretas pelo governo imperial para completar os quadros da força armada, a vivência cotidiana dos soldados, entre outros. Além de seu caráter informativo, essas obras são significativas na medida em que levaram a pensar o Exército sob outros prismas - em particular o social - que não simplesmente aquele das estratégias de guerra ou das táticas de batalha.

Por sua vez, o período histórico do Primeiro Reinado e as questões ligadas aos direitos dos cidadãos tornaram-se focos de muitos estudos nos últimos anos, após longo período olvidados ou tratados de maneira secundária pela historiografia. De acordo com Gladys Ribeiro e Vantuil Pereira, o período histórico do Primeiro Reinado foi tratado por muito tempo como tampão entre a independência política em 1822 e a "verdadeira"

\footnotetext{
${ }^{4}$ Entre as obras deste período, pode-se destacar:

CASTRO, Celso. A invenção do Exército. Rio de Janeiro: Jorge Zahar Editor, 2002; CASTRO, Celso; IZECKSOHN, Vitor; KRAAY, Hendrik (Orgs.). Nova História Militar Brasileira. Rio de Janeiro: Editora FGV, 2004; CARVALHO, José Murilo de. Forças Armadas e Política no Brasil. Rio de Janeiro: Jorge Zahar Editor, 2006; DORATIOTO, Francisco M. General Osório: a espada liberal do Império. São Paulo: Companhia das Letras, 2008; ___ Maldita Guerra. São Paulo: Companhia das Letras, 2002; KRAAY, Hendrik. Política Racial, Estado e Forças Armadas na época da Independência: Bahia, 1790-1850. São Paulo: Hucitec editora, 2011; SALLES, Ricardo. Guerra do Paraguai: escravidão e cidadania na formação do exército. Rio de Janeiro: Paz e Terra, 1990; SOUZA, Adriana Barreto de. Duque de Caxias: o homem por trás do monumento. Rio de Janeiro: Civilização Brasileira, 2008.

${ }^{5}$ MCBETH, Michael Charles. The politicians vs. the generals: the decline of the Brazilian army during the First Empire. University of Washington: dissertation for the degree of doctorship, 1972.

MENDES, Fábio Faria. Recrutamento militar e construção do Estado no Brasil imperial, Belo Horizonte: Argvmentvm, 2010.

SOUZA, Adriana Barreto de. O exército na consolidação do Império: um estudo histórico sobre a política militar conservadora. Rio de Janeiro: Arquivo Nacional, 1999.
} 
independência do jugo português em 1831 com a abdicação de Pedro I, quando, finalmente, o poder passou para mãos brasileiras. ${ }^{6}$

O interesse renovado de estudo do I Reinado e da cidadania levou vários estudiosos a verem na constituição de 1824 , nos instrumentos de acesso ao poder que ela fornecia, nos direitos nela garantidos e nos debates parlamentares do período, marcos importantes da cidadania no Brasil. Nesses esforços de renovação historiográfica, várias questões foram suscitadas como a fundação do sistema constitucional, das instituições e do aparato jurídico imperiais; o relacionamento da população com o Estado e suas autoridades, a maneira pela qual grupos reivindicavam seus direitos; as discussões sobre as fontes da soberania nacional, entre outros. ${ }^{7}$

A questão da cidadania no Brasil imperial não é um tema particularmente novo na historiografia brasileira, embora tenha se tornado bastante atual nas últimas décadas. Em resposta a uma produção que considerava o liberalismo no Brasil "fora de lugar” e o acesso à cidadania política pouco alargado, que não cabe ser aprofundada aqui, ${ }^{8}$ surgiu uma série de trabalhos acerca da cidadania no Império que buscaram os mecanismos de

${ }^{6}$ RIBEIRO, Gladys; PEREIRA, Vantuil. O Primeiro Reinado em revisão. In GRINBERG, Keila; SALLES, Ricardo. O Brasil Imperial, vol. 1. Rio de Janeiro: Civilização Brasileira, 2009. Entre autores que o abordaram desta maneira, pode-se citar Caio Prado Junior. PRADO JR., Caio. Evolução política do Brasil e outros estudos. São Paulo: Brasiliense, 1979.

${ }^{7}$ Nesse movimento podem ser incluídas as seguintes obras:

CARVAlHO, José Murilo de; CAMPOS, Adriana Pereira (Orgs.). Perspectivas da cidadania no Brasil Império. Rio de Janeiro: Civilização Brasileira, 2011.

GRINBERG, Keila; SALLES, Ricardo (Orgs.). O Brasil Imperial, vol. 1. Rio de Janeiro: Civilização Brasileira, 2009.

JANCSÓ, Istvan (Org.). Independência: história e historiografia. São Paulo: Hucitec, 2005.

MATTOS, Hebe Maria. Escravidão e cidadania no Brasil Monárquico. Rio de Janeiro: Jorge Zahar Editor, 2000.

NEVES, Lúcia Maria Bastos Pereira das. Corcundas e constitucionais. Rio de Janeiro: Revan: FAPERJ, 2003.

RIBEIRO. Gladys (Org.). Brasileiros e cidadãos: modernidade política. São Paulo: Alameda, 2008.

. A Liberdade em construção. Rio de Janeiro: Relume Dumará: FAPERJ, 2002.

${ }^{8}$ CARVAl $H O$, José Murilo de. Desenvolvimiento de la Ciudadanía en el Brasil. México: Fondo de Cultura Económica, 1995.

FAORO, Raymundo. Os donos do Poder: formação do patronato político brasileiro. São Paulo: Globo, 2008.

GRAHAM, Richard. Ciudadanía y Jerarquia em el Brasil esclavista In: SÁBATO, Hilda. Ciudadanía política y formación de las naciones: perspectivas históricas de América Latina. México: Fondo de Cultura Económica, 1999.

KLEIN, Herbert. A participação política no Brasil do século XIX: os votantes de São Paulo em 1880. Dados - Revista de Ciências Sociais, vol. 38, nº 3, 1995, p. 527-544.

SAES, Décio. A formação do Estado burguês no Brasil (1888-1889). Rio de Janeiro: Paz e Terra, 1985.

SCHWARTZ, Robert. Ao vencedor as batatas. São Paulo: Duas Cidades, 1977.

Para maiores conhecimentos acerca deste debate historiográfico, ver:

GRINBERG, Keila. O Fiador dos Brasileiros. Rio de Janeiro: Civilização Brasileira, 2002, p. 27-32.

PEREIRA, Vantuil. “Ao Soberano Congresso": Petições, Requerimentos, Representações e Queixas à Câmara dos Deputados e ao Senado - Os direitos do cidadão na formação do Estado Imperial brasileiro (1822-1831). Tese de doutorado: Universidade Federal Fluminense, 2008, p. 15-22. 
acesso da população às esferas do poder, a defesa dos direitos civis, as ideias nas quais as elites políticas daquele período embasavam uma defesa de maior ou menor participação popular no governo.

Alguns autores, como Vantuil Pereira e Keila Grinberg destacaram a participação de parte da população nos espaços institucionais do Brasil Imperial. O primeiro intenta em seu trabalho indicar como o mecanismo das petições ${ }^{9}$ permitiu um alargamento da participação popular nas esferas decisórias de poder. Por essas petições, os grupos com acesso à escrita, inclusive as mulheres, tinham a possibilidade de intervir no jogo político, denunciando supostos abusos de autoridades, sugerindo novas leis, pedindo a intercessão do Parlamento para resolver problemas enfrentados junto ao Executivo. Por outro lado, essas petições, endereçadas principalmente à Câmara dos Deputados, abriram um espaço de atuação legítimo para a nova instituição, que, na primeira legislatura, ainda lutava para se tornar o principal locus de poder do Império.

A segunda autora estudou a figura de André Rebouças e sua luta no Parlamento em favor dos direitos civis e políticos de libertos. A partir de sua pesquisa defendeu como tese que

(...) a "cara do Estado" vista pela população brasileira foi por vezes atraente; que houve, a partir da independência do país, uma efetiva pressão de distintos setores da sociedade brasileira pelo reconhecimento de seu direito à cidadania, e que este movimento partiu principalmente daqueles indivíduos que tinham vivido diretamente ou através de seus antecessores a experiência da escravidão. ${ }^{10}$

É importante destacar que embora a historiografia se utilize da palavra "cidadania" para se referir ao conjunto das garantias do cidadão, neste trabalho se emprega a expressão "direitos do cidadão" uma vez que a primeira não aparece na documentação analisada.

É na intersecção desse duplo movimento historiográfico que se insere a pesquisa que resultou na presente dissertação. A partir das bases lançadas por esse conjunto de obras elencado, foi possível investigar os direitos que os soldados adquiriram a partir do movimento constitucional da década de 1820 no Império e das reformas propostas pelos parlamentares no período.

\footnotetext{
${ }^{9}$ Este direito foi estipulado no artigo 179, inciso XXX da constituição imperial, em que se lê: "Todo o Cidadão poderá apresentar por escrito ao Poder Legislativo e ao Executivo reclamações, queixas, ou petições, e até expor qualquer infração da Constituição, requerendo perante a competente Autoridade a efetiva responsabilidade dos infratores".

${ }^{10}$ GRINBERG, O Fiador dos Brasileiros, p. 32.
} 
Para realizar esta investigação, recorreu-se a dois conjuntos principais de fontes: os anais da Câmara dos Deputados da primeira legislatura (1826-1829) e do primeiro ano da legislatura seguinte (1830), e as normas ${ }^{11}$ militares do Império promulgadas entre 1820 e 1830.

No primeiro conjunto de documentos, rastrearam-se os debates parlamentares acerca de questões militares realizadas no âmbito da Câmara dos Deputados. Buscaramse nestes, particularmente, as opiniões dos representantes brasileiros em relação aos direitos dos cidadãos quando no serviço das armas, ao tempo de serviço obrigatório, ao serviço dos soldados voluntário e dos forçados, à punição cabível às faltas e aos crimes militares cometidos em paz e em guerra.

No segundo grupo de fontes, pesquisaram-se quais eram os regulamentos válidos para o Exército, como o governo organizava o recrutamento, quais grupos estavam sujeitos ao serviço das armas e de que forma o Executivo lidou com a punição aos soldados desertores.

Este trabalho se justifica, assim, na medida em que traz nova contribuição aos estudos da cidadania nos primórdios do Brasil independente e à historiografia militar ao lançar um entendimento sobre o serviço dos soldados e seus direitos durante um período da história brasileira em que o Exército não foi objeto de grandes estudos.

De modo a bem realizar as análises de fonte e alcançar o objetivo proposto, foram necessários alguns aportes teóricos, a saber: as considerações acerca do tempo histórico, da história dos conceitos e do direito como elemento constitutivo da realidade político-social.

As questões a respeito do tempo histórico e dos conceitos foram inspiradas nos trabalhos de Reinhart Koselleck. ${ }^{12}$ Numa série de escritos teóricos, Koselleck afirma que a Europa durante o período histórico de 1750-1850, chamado por ele de Sattelzeit, passou por profundas transformações políticas e sociais que acabaram por levar a uma

\footnotetext{
${ }^{11}$ Entende-se por norma um "imperativo de um comando e se caracteriza por uma linguagem prescritiva que atua sobre as condutas intersubjetivas (...). É uma prescrição. São os documentos prescritivos do direito. Implicam o dever-ser em estado potencial, lançado para o futuro que pode ocorrer". Cf. SANTOS, Mírian. Norma Jurídica: uma questão de linguagem. Veredas - Rev. Est Ling., Juiz de Fora, v. 9, n.1 e n.2, p. 107-121, jan./dez., 2005, p. 111.

${ }^{12}$ KOSELLECK, Reinhart. Futuro Passado. Rio de Janeiro: Contraponto, 2006. . Linguistic change and the History of Events. The Journal of Modern history, vol. 61, n. 4 (Dec. 1989), p. 649-666.

Los Estratos Del Tiempo: Estudios Sobre La Historia. Mexico: Paidos, 2001.

The practice of conceptual history. Timing history, spacing concepts. Stanford: Stanford University, 2002.
} 
mudança na maneira como diferentes grupos sociais passaram a articular o passado, o presente e o futuro, ou melhor, como passaram a perceber e vivenciar o tempo histórico.

O período de fins do século XVIII e início do século XIX foi marcado por um enfraquecimento das bases tradicionais de soberania e poder das monarquias absolutas ${ }^{13}$ da Europa. Esse processo assumiu tons dramáticos com as Revoluções Americana e Francesa de fins do século XVIII. Tais eventos puseram abaixo a ordem estabelecida nas colônias britânicas da América e na França dos Bourbons e fundaram novas organizações políticas. Embora a criação dos Estados Unidos da América tenha impactado fortemente os governos das demais colônias americanas por sua ousadia em desafiar sua antiga metrópole, foi, em particular, o processo revolucionário francês que repercutiu mais intensamente na Europa e no mundo Ocidental.

Os eventos que se seguiram à tomada da Bastilha em 14 de julho de 1789 trouxeram à tona as fragilidades e fraturas do edifício político do Antigo Regime - na França e nas demais monarquias da Europa - que não tardou a se transformar em ruínas. Dessa forma, o futuro se abria a indeterminadas possibilidades e expectativas, enquanto o passado tornava-se cada vez menos referência para as mudanças a serem realizadas.

A revolução francesa acabou por levar a uma nova relação dos diversos grupos sociais com o próprio tempo histórico, que, como dito acima, refere-se à articulação que diferentes grupos humanos fazem entre passado, presente e futuro, ou entre a experiência atualizada do passado e a expectativa antecipada de futuro. ${ }^{14}$ A partir de fins do século XVIII, essa relação temporal tornou-se assimétrica, com o passado deixando cada vez mais de informar a experiência do presente e guiar a ação para o futuro, e este passou a ser entendido como diferente e melhor que o passado, tempo em que se haveria

\footnotetext{
${ }^{13}$ Entende-se por monarquia absoluta a forma de governo em que o rei é a maior autoridade política do reino e detentor da soberania. Isso não significa dizer, no entanto, que o monarca absoluto tivesse a capacidade e o direito de agir conforme sua vontade. Na tradição política moderna das monarquias corporativas, o rei absoluto estava limitado em sua ação pelos direitos divino e natural e pelos costumes do reino, servindo de árbitro e distribuindo a justiça em seu domínio. Em outras palavras, ele não deveria, em suas atribuições, ir contra os direitos estabelecidos dos corpos que compunham a sociedade. Esta definição difere daquela de "absolutismo", conceito cunhado no bojo da revolução e concatenado ao de "Antigo Regime", que associava a forma de governo anterior ao movimento revolucionário com tirania e despotismo, conceitos que passaram a ser utilizados de maneira intercambiável no vocabulário dos liberais do século XIX.

FURET, François. Antigo Regime. In: FURET, François; OZOUF, Mona. Dicionário Crítico da Revolução Francesa. Rio de Janeiro: Ed. Nova Fronteira, 1989, p. 621-632.

HESPANHA, António Manuel; XAVIER, Ângela Barreto. A representação da sociedade e do Poder. In: HESPANHA, António Manuel (coord.). História de Portugal: Antigo Regime. Lisboa: Editorial Estampa, 1993, p. 121-155.

KIRSCHNER, Tereza Cristina. A reflexão conceitual na prática historiográfica. Textos de História, v. 15, n. $1 / 2$ (2007), p. 53.

${ }^{14}$ KOSELLECK, Futuro Passado, p. 312.
} 
de alcançar a plena realização e felicidade humanas. Tal imbricamento temporal marcou o período da modernidade e foi sintetizado pelo conceito ${ }^{15}$ de "progresso". ${ }^{16}$

O Brasil não passou incólume por todo esse processo. Com a subida de Napoleão ao poder em 1799, a guerra revolucionária se espalhou como rastilho de pólvora pela Europa e não tardou a alcançar a península Ibérica. Encurralada numa rede de alianças e ameaças de invasão, a família real portuguesa decidiu migrar para suas possessões americanas, evento singular na história europeia e de inflexão na história da colônia.

O estabelecimento dos Bragança em terras brasileiras em 1808 marcou profundamente as relações econômicas e políticas estabelecidas há muito entre colonos e reinóis. Ao tornar-se sede da monarquia lusa e ser elevado à categoria de Reino Unido a Portugal em 1815, o Brasil passava a ser o centro do império ultramarino, invertendo o antigo nexo que unia ambas as unidades políticas. $\mathrm{O}$ descontentamento com a situação em que se encontravam levou os lusitanos a um movimento revolucionário a partir da cidade do Porto em 1820 e que não tardou a obter a completa adesão no reino. Reivindicaram o retorno do rei e a criação de um governo constitucional. Os choques entre os "portugueses dos dois lados do Atlântico" foram se agravando entre os anos de 1820 e 1822 até que os grupos políticos reunidos em torno da figura do príncipe português, regente do Reino do Brasil, optaram pela cesura. Era fundado o Império do Brasil sob o signo da continuidade dinástica dos Bragança.

A independência política do Império "fez surgir um novo regime de historicidade no Brasil (...) que ressignificou o passado em função das complexas questões que se apresentavam à época". ${ }^{17}$ À reinterpretação do passado colonial como "tirânico" e "despótico" pela ausência de constituição e de instituições como o Parlamento, a classe política brasileira conjugava uma expectativa de futuro marcada

\footnotetext{
${ }^{15}$ A definição de conceito é aqui empregada com o sentido dado por Reinhart Koselleck:

"Ainda que os significados abstratos e conceitos estejam associados a seus significantes (as palavras) eles se nutrem também do conteúdo suposto, do contexto falado ou escrito e da situação social. Isso vale inicialmente para ambos, palavras e conceitos. O sentido de uma palavra pode ser determinado pelo seu uso. Um conceito, ao contrário, para poder ser um conceito, deve manter-se polissêmico. Embora o conceito também esteja associado à palavra, ele é mais do que uma palavra: uma palavra se torna um conceito se a totalidade das circunstâncias político-sociais e empíricas, nas quais e para as quais essa palavra é usada, se agrega a ela. (...) São vocábulos nos quais se concentra uma multiplicidade de significados. (...) Uma palavra contém possibilidades de significado, um conceito reúne em si diferentes totalidades de sentido." KOSELLECK, Futuro Passado, p. 109.

${ }^{16}$ KOSELLECK, Futuro Passado, p. 327.

17 KIRSCHNER, Tereza Cristina. Um pouco de Historiografia. A representação do passado colonial brasileiro a partir da independência. Anais de História de Além-Mar, v. X, 2010, p. 259.
} 
pelo império das leis. Os esforços de criação de um novo país acentuavam, assim, para a elite dirigente do Império, o sentimento de se viver um novo tempo aberto a mudanças.

Muitas eram as dificuldades apresentadas aos grupos políticos coevos: a manutenção da unidade territorial, a criação de um sistema constitucional, a guerra com Portugal, a necessidade de reconhecimento pelas demais unidades políticas, a reorganização financeira e monetária, para citar alguns exemplos. Todos esses obstáculos tiveram papel de destaque na Assembleia Constituinte de 1823 e nas discussões da Câmara dos Deputados, a partir da primeira legislatura iniciada em $1826 .{ }^{18}$

Nesse ambiente de deliberações políticas, os deputados "representantes da nação" deixavam claro em seus discursos a necessidade de se implementar mais e melhores leis e atestavam que muito havia por se fazer para superar a herança colonial e o que eles consideravam as "vexações" e "abusos" daquele tempo. ${ }^{19}$ Tal aspecto nos dá indícios de que esse grupo político, ainda que heterogêneo em sua composição, possuía a consciência de que eram agentes capazes de alterar seu próprio mundo e construir um Estado que trouxesse segurança, paz e estabilidade a seus concidadãos. Nesse sentido, pode-se sustentar que a elite política imperial dos tempos da independência vivenciava de maneira similar a assimetria entre espaço de experiência e horizonte de expectativa de que se falou anteriormente para o caso europeu. ${ }^{20} \mathrm{E}$ a abertura para o futuro os impulsionava a construir um Estado-nacional unido e consolidado, o que passava pela (re)organização das forças armadas, objeto deste trabalho.

Por fim, o terceiro referencial para esta inquirição é o papel do direito na construção das instituições de Estado e, em particular, da capacidade da produção legislativa de alterar o status quo em busca de um futuro diferente.

No período que vai dos séculos XVI ao XVIII, a cultura jurídica europeia passou por um processo de transformação que levou - num processo não linear, com avanços e recuos - em linhas gerais a uma centralização da administração e da produção legislativa em instituições como as Coroas, os Parlamentos ou as Assembleias nacionais - a variar conforme o período e os países do continente -, em detrimento das demais fontes e núcleos de direito que marcaram a época moderna e as monarquias

\footnotetext{
${ }^{18}$ PEREIRA, Ao Soberano Congresso..., 2008.

${ }^{19}$ A ideia de que muito ou tudo estava por se fazer em relação à construção do edifício político do Estado é repetida por vários deputados no ano de 1826.

20 ARAÚJO, Valdei Lopes de. A experiência do tempo na formação do Império do Brasil: autoconsciência moderna e historicização. Revista de História 159 (2ºmestre de 2008), p. 107-134.
} 
corporativas, como o direito das universidades, das corporações de ofício, dos Senados das câmaras, da Igreja, dentre outros tantos.

Esse movimento conheceu grande impulso em Portugal com os esforços administrativos do Marquês de Pombal e sua lei da Boa Razão de 1769, e com os códigos militares do conde de Schaumbourg-Lippe, primeira experiência codificadora do reino luso. No quadro europeu mais geral, a centralização administrativa e legislativa ganharia força com a promulgação dos códigos napoleônicos.

Essas experiências dão-nos indícios do nascimento de uma nova concepção jurídica que despontava no período, "caracterizada por um caráter legalista (...) responsável por uma identificação entre 'lei e direito",. ${ }^{21}$ A partir de então, o direito consuetudinário gradativamente foi dando lugar para o direito positivo em vários países da Europa. ${ }^{22}$

O Brasil imperial e os Estados da América hispânica seguiram esse mesmo caminho codificador. Nesses países, a lei teve papel fundamental na construção do Estado nacional, tornando-se fonte de emanação de direitos e instrumento de superação das heranças coloniais. Essa transformação paulatina do passado colonial e a fundação de uma nova ordem jurídica teve início no Brasil logo no Primeiro Reinado, com o movimento constitucionalista, a convocação da Assembleia Constituinte em 1823, a outorga da Constituição de 1824 e a convocação da Assembleia Geral em 1826, continuando século XIX adentro com a formação dos cursos jurídicos nacionais. ${ }^{23} \mathrm{Com}$ o fechamento da Assembleia Constituinte, caberia à Assembleia Geral, já sob a luz da Carta imperial, a tarefa de reformar o aparato jurídico então existente e reconstruí-lo sob égides constitucionais. Isto

\begin{abstract}
fez parte de uma atitude consciente e dirigida de nossos primeiros legisladores que usaram a "faculdade de legislar como primeira fonte de todo direito" na consolidação de um ideário de Estado, ou seja, valendo-se da apropriação do sentido mais moderno então existente para a "lei". Esse caráter legalista frutificaria nos trabalhos das primeiras legislaturas, numa clara ênfase na organização do Estado sob um perfil eminentemente liberal que, em ambiente de profunda luta política, punha-se como primeira necessidade. ${ }^{24}$
\end{abstract}

\footnotetext{
${ }^{21}$ SLEMIAN, Andréa. Sob o Império das leis. São Paulo: Unesp, 2009, p. 35.

${ }^{22}$ SCHIOPPA, Antonio Padoa. História do Direito na Europa. São Paulo: Martins Fontes, 2014, p. 340.

${ }^{23}$ APOSTOLOVA, Bistra Stefanova. A criação dos cursos jurídicos no Brasil: Tradição e inovação. Tese de Doutorado: Universidade de Brasília, 2014.

LOPES, José Reinaldo de Lima.Iluminismo e jusnaturalismo no ideário dos juristas da primeira metade do século XIX. In: JANCSÓ, István. Brasil: formação do Estado e da Nação. São Paulo: Hucitec, 2003, p. 195-218.

SLEMIAN, Sob o Império das leis, p. 35.

${ }^{24}$ SLEMIAN, Sob o Império das leis, p. 35.
} 
Somente é possível compreender o papel transformador do direito e da lei, tal como entendia esse grupo político dirigente do Primeiro Reinado, se se considerar a

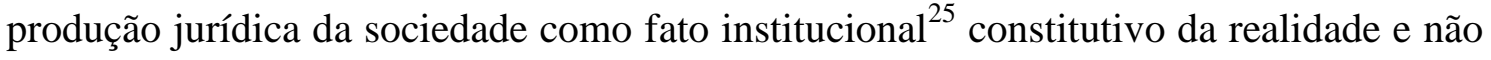
como mero epifenômeno da infraestrutura da sociedade ou uma "capa sobre uma realidade social". ${ }^{26}$ Entendido como fato institucional, o direito não trata de "fatos brutos" mas existe, como fato real, na relação humana mediada pela linguagem. Como afirma José Reinaldo de Lima Lopes:

A constituição do direito não é a descoberta de alguma coisa já feita: é a
invenção de uma realidade social, cuja existência dá-se apenas na esfera das
interações e práticas humanas. Trata-se (...) de equiparar o direito (...) à
linguagem e ao discurso: a língua portuguesa (...) não tem a mesma natureza
fictícia de um Papai Noel. Mas tampouco existe como existe uma pedra.
Existe apenas como uma prática, e prática segundo regras. Se o direito é um
fato institucional e se esse fato institucional não se pode se separar da
linguagem, as mudanças na linguagem respectiva correspondem a mudanças
no próprio objeto. ${ }^{27}$

Nesse sentido, os grupos políticos dirigentes e legisladores, ${ }^{28}$ ao estatuírem normas que concediam aos soldados direitos civis, alteraram o modo como se entendia a ocupação militar, o que envolvia ser um soldado, os limites de suas ações e de seus chefes.

Sinteticamente, essas orientações teóricas acerca do tempo histórico e do direito como fato institucional foram fundamentais para guiar a pesquisa e o exame dos documentos escolhidos para a realização deste trabalho.

Estruturalmente, esta dissertação se divide em três capítulos. O primeiro aborda o contexto mais geral do movimento constitucional luso-brasileiro. Tratou-se do movimento da independência do Império, da formação das primeiras instituições políticas e do papel do direito nesse momento histórico. O objetivo do capítulo é

\footnotetext{
${ }^{25}$ Utiliza-se aqui a definição dada por John Searle:

"Institutional facts are so called because they require human institutions for their existence. In order that this piece of paper should be a five dollar bill, for example, there has to be the human institution of money. Brute facts require no human institution for their existence. Of course, in order to state a brute fact we require the institution of language, but the fact stated needs to be distinguished from the statement of it." SEARLE, John R. The construction of social reality. New York: The Free Press, 1995, p. 2.

${ }^{26}$ LOPES, José Reinaldo Lima de. As palavras e as leis. São Paulo: Editora 34, 2004, p. 33.

${ }^{27}$ Ibidem, p. 30.

${ }^{28}$ No caso do Exército, antes da reunião da Assembleia Geral em 1826, o Ministério da Guerra foi o responsável pela regulamentação da instituição. Instaurado o Parlamento, ele passou a ser, de acordo com a Constituição, o locus decisório e legislador. Esse papel, no entanto, somente passou a ser exercido de fato a partir de 1830 com as elaborações anuais dos anos financeiros em que se decidia o tamanho das forças armadas, as novas leis de recrutamento, a criação da Guarda Nacional etc. Entre 1826 e 1830 a Câmara dos Deputados disputou com o Ministério da Guerra e com o Imperador a proeminência legislativa/regulatória acerca dessa instituição, razão de muitos conflitos e tensões entre ambas as partes.
} 
apontar que essas transformações políticas mais gerais resultaram também em reflexões acerca do papel do Exército e dos soldados num Estado que se propunha a garantir os direitos individuais de seus cidadãos.

O segundo capítulo adentra a questão do recrutamento durante o Primeiro Reinado. Nessa parte foi abordada a organização geral das tropas do Império, apresentando rapidamente a maneira como se dividia, sua hierarquia e algumas indicações de salário e da vida dos soldados. Em seguida, foram expostas as normas emitidas pelo governo que deveriam orientar o trabalho dos recrutadores, em particular as instruções para o recrutamento feitas e promulgadas pelo então regente d. Pedro em 10 de julho de 1822. Por fim, foram analisados debates da primeira legislatura na Câmara dos Deputados que mostraram o que os homens ali reunidos pensavam do serviço das armas e o que propunham para coibir abusos. O objetivo é assinalar a preocupação por parte da elite política em readequar as práticas do recrutamento e em pensar quem era recrutável à luz das novas bases constitucionais do Estado.

O terceiro capítulo, enfim, trata dos castigos no Exército do Primeiro Reinado. Em primeiro lugar, apresentaram-se as diretrizes gerais para os castigos na instituição, em particular o regulamento do Conde Schaumboug-Lippe. Logo após, foram examinadas as determinações do governo imperial sobre os castigos a serem aplicados a soldados infratores, como também os decretos de perdão expedidos aos desertores. Por fim, foram analisados os discursos e as críticas feitas pelos deputados do Império sobre os castigos na força militar. $O$ intento dessa seção foi assinalar como também os castigos foram repensados a partir do movimento constitucionalista da década de 1820 e da necessidade de garantir os direitos dos soldados e cidadãos brasileiros. 


\section{Legem habemus: o constitucionalismo, a Independência e a fundação do Brasil sob o império da lei}

Em 4 de Maio de 1826, na sexta sessão preparatória para a reunião da Assembleia Geral do Império do Brasil, reuniram-se no prédio da Cadeia Velha, na Corte do Rio de Janeiro, 53 homens eleitos deputados. Sob a presidência provisória de Pereira da Nóbrega, ${ }^{29}$ os representantes eleitos para a primeira legislatura do Parlamento brasileiro discutiam nesse dia como seria composta a deputação a ser enviada ao Imperador para obter dele a data e o local em que se instalaria a dita Assembleia. ${ }^{30}$ Para alguns deputados, como Souza França ${ }^{31}$ e Marcos Antônio ${ }^{32}$, a deputação deveria possuir 12 membros, o dobro daquela a ser formada pelos senadores - mantendo assim, o paralelo constitucional entre o número de deputados e o número de senadores. ${ }^{33}$

\footnotetext{
${ }^{29}$ Luís Pereira da Nóbrega de Sousa Coutinho (1760-1826) foi eleito para a primeira legislatura do Império (1826-1829) pelo Rio de Janeiro. Ocupou o cargo de presidente durante as sessões preparatórias, continuando como tal depois de instalada a Câmara até o fim do primeiro ano da legislatura. Militar, chegou ao posto de tenente-general e foi alçado ao ministério da guerra, pasta que ocupou de junho a outubro de 1822 .

${ }^{30}$ BRASIL. Anais da Câmara dos Deputados (ACD), sexta sessão preparatória, 4 de maio de 1826, tomo I, p. 20.

${ }^{31}$ Deputado da Constituinte de 1823 pelo Rio de Janeiro, eleito pela mesma província para integrar a primeira legislatura imperial. Foi secretário da Casa legislativa durante as sessões preparatórias e manteve-se no cargo depois de sua instalação definitiva em 6 de maio de 1826. Destacou-se por discursos moderados na Câmara.

${ }^{32}$ Nascido no Maranhão, foi oficial do Exército, chegando até o posto de brigadeiro por ocasião de sua reforma. Foi eleito duas vezes para a Câmara dos Deputados: na primeira legislatura (1826-1829) pelo Ceará e na sexta (1845-1847) pelo Pará. Obteve o título de barão de Jaguarari, foi comendador da ordem de Avis e da ordem militar napolitana de S. Jorge, oficial da ordem da Rosa e cavaleiro da ordem do Cruzeiro.

${ }^{33}$ Tal como se lê no artigo 41 da Constituição de 1824: "Cada Província dará tantos Senadores, quantos forem metade de seus respectivos Deputados, com a diferença, que, quando o número dos Deputados da Província for ímpar, o número dos seus Senadores será metade do número imediatamente menor, de maneira que a Província, que houver de dar onze Deputados, dará cinco Senadores". Tendo o Senado estabelecido uma deputação de 6 membros, a Câmara deveria formar uma outra de 12 para manter a mesma lógica de composição das Casas.
} 
Contra esse argumento, Teixeira de Gouveia ${ }^{34}$ evocou o regimento da Assembleia Constituinte de 1823, que havia se tornado lei um dia antes. Disse ele:

Sr. Presidente, nós legem habemus: eu sigo a lei, não sei outra linguagem. Temos um regimento próprio, que ontem se decidiu que é lei. Siga o Senado o que quiser. Nós não podemos deliberar, se não sobre o que se acha recebido nesta Câmara; pois seria inconsequência haver-se decidido que os artigos do regimento obrigavam como lei e violarmos já hoje esta lei. Portanto digo que a deputação não pode senão ter 24 membros. Para o que requeiro que se mande vir do arquivo o livro das atas de 10 e 11 de Junho de 1823, e que o Sr. Secretário leia o que se venceu a este respeito. ${ }^{35}$

$\mathrm{O}$ argumento parece ter convencido os demais colegas, que acabaram por aprovar, depois de breve arrazoado, a proposta feita de uma deputação de 24 membros.

Esse pequeno episódio, irrisório se comparado com os demais objetos discutidos no Parlamento, permite entrever a importância que a lei, como norma a ser seguida, passava a ter naquele momento. Como o grupo de representantes da nação, eleitos para decidirem os rumos do novo Império, tendo aprovado uma lei em um dia, desrespeitála-iam no dia seguinte? Fazer cumprir a lei era tarefa imprescindível para a construção desse novo Estado e vários deputados pareciam ter essa consciência, a julgar pelos discursos analisados. ${ }^{36}$ Era imprescindível, portanto, adequar o aparato jurídico aos novos princípios expressos na Constituição, atualizando ou revogando aquele herdado do período colonial e da experiência como Reino Unido a Portugal. Essa incumbência lhes fora dada pela própria Carta, no inciso XVIII do artigo 179, em que manda organizar os códigos Civil e Criminal sob as bases da Justiça e da Equidade.

É a respeito da construção do Império sob essa égide constitucional que se pretende discutir neste capítulo. Acredita-se que somente após um entendimento acerca do ambiente e do contexto político de formação do novo país, pode-se compreender o papel da lei - e a abertura para mudança que ela proporciona - na transformação dos soldados do Exército em cidadãos portadores de direitos individuais.

\footnotetext{
${ }^{34}$ Natural de Mariana, MG, Lúcio Soares Teixeira de Gouveia (1792-1838) foi um magistrado e político brasileiro. Foi deputado nas Cortes Constituintes de Portugal, deputado na Assembleia Constituinte do Império em 1823, deputado na primeira legislatura por Minas Gerais, Ministro da Justiça por duas ocasiões: entre 20/11/1827 e 18/06/1828 e depois entre 22/11/1828 e 4/12/1829. Foi senador do Império de 1837 a 1838.

${ }^{35}$ ACD, sexta sessão preparatória, 4 de maio de 1826, tomo I, p. 20.

${ }^{36}$ Pode-se citar o exemplo do discurso de Souza França na sessão preparatória de 5 de maio de $1826 \mathrm{em}$ que disse: "Nunca votarei, para que esta Câmara viole a constituição, e as leis, ainda nos casos mais insignificantes; porque daí se deduzem exemplos mui perigosos para o futuro". ACD, sétima sessão preparatória, 5 de maio de 1826, tomo I, p. 23.

SLEMIAN, Andrea. Sob o Império das Leis. São Paulo: Hucitec, 2009, p. 17-44.

PEREIRA, Vantuil. Ao Soberano Congresso. São Paulo: Alameda, 2010, p. 102.
} 


\subsection{Na esteira do Constitucionalismo nasce um novo Estado}

A construção do Império do Brasil foi objeto de muitas e variadas interpretações. O processo que levou à independência de Portugal, a manutenção da unidade territorial frente à fragmentação das ex-colônias hispano-americanas, a escolha da continuidade do modelo monárquico num continente em que os demais países constituíam-se como repúblicas e a conservação do escravismo como base da organização socioeconômica foram algumas questões que motivaram uma rica produção historiográfica. ${ }^{37}$

Não obstante esses multifacetados temas e abordagens da história do Império, um aspecto parece ter ficado à margem das vistas dos historiadores até as duas últimas décadas. Trata-se da questão da fundação das instituições jurídicas, da formação de um direito nacional e constitucional e de sua importância na organização e estruturação do Estado imperial. Este olvidamento é em parte decorrente da análise feita sobre a história do Primeiro Reinado no Brasil, abordada por já mencionada historiografia como "período tampão" da história brasileira, ${ }^{38}$ entre a independência em 1822, feita por um príncipe português, e a "verdadeira libertação nacional que seria o 7 de abril". ${ }^{39}$ Tal postura frente a primeira década independente do Império acabou por negligenciar o estudo da construção do edifício legal, institucional, político e jurídico que tomou parte

\footnotetext{
${ }^{37}$ Dentre o grande número de textos e obras que trabalharam com essa temática, podemos citar: BARMAN, Roderick. Brazil: the forging of a nation. Stanford: Stanford University press, 2003. CARVALHO, José Murilo de. A construção da Ordem: a elite política imperial. Teatro de sombras: a política imperial. Rio de Janeiro: Civilização Brasileira, 2010.

DIAS, Maria Odila L. da Silva. A interiorização da metrópole e outros estudos. São Paulo: Alameda, 2005.

GRINBERG, Keila; SALLES, Ricardo. O Brasil Imperial, vol. I. Rio de Janeiro: Civilização Brasileira, 2009.

JANCSÓ, István; PIMENTA, João Paulo. Peças de um mosaico (ou apontamentos para o estudo da emergência da identidade nacional brasileira). In: MOTA, Carlos Guilherme. Viagem Incompleta. São Paulo: SENAC, 2000, p. 129-175.

JANCSÓ, István (Org). Brasil: formação do Estado e da Nação. São Paulo: Hucitec, 2003.

Independência: história e historiografia. São Paulo: Hucitec, 2005.

LIMA, Oliveira. O movimento de independência. Rio de Janeiro: Topbooks, 1997.

LYRA, Maria Lourdes Viana. A utopia do Poderoso Império. Rio de Janeiro: Sette Letras, 1994.

MATTOS, Ilmar Rohloff. O tempo saquarema. Rio de Janeiro: Access, 1994.

MAXWELL, Kenneth. Por que o Brasil foi diferente? O contexto da independência. In: MOTA, Carlos Guilherme. Viagem Incompleta. São Paulo: SENAC, 2000.

RODRIGUES, José Honório. Independência: revolução e contra-revolução. Rio de Janeiro: Biblioteca do Exército Editora, 2002.

SOUZA, Iara Lis Carvalho de. Pátria Coroada: O Brasil como Corpo político autônomo. São Paulo: Unesp, 1999.

SZMRECSÁNYI, Tamás; LAPA, José R. do A. (Orgs.). História econômica da Independência e do Império. São Paulo: Hucitec, 1996.

38 RIBEIRO, Gladys Sabina; PEREIRA, Vantuil. O I Reinado em Revisão. In: GRINBERG, Keila; SALLES, Ricardo. O Brasil imperial, vol. I. Rio de Janeiro: Civilização Brasileira, 2009, p. 140.

${ }^{39}$ Idem.
} 
nessa época. Edifício este que possuiu longa vida, perpassando quase incólume toda a experiência monárquica brasileira. ${ }^{40}$

Nestes últimos dez anos alguns estudos voltaram-se para esse objeto, ressaltando as dificuldades, as ambiguidades, as disputas e o terreno fértil das questões jurídicas no início do Brasil imperial e indicando os diversos caminhos disponíveis para a construção do direito no Império, suas matrizes teóricas e seus limites. ${ }^{41}$ O que lhes parece consensual é, por um lado, a inserção do Império do Brasil num movimento constitucional mais amplo do mundo Atlântico - na esteira dos eventos ocorridos na Europa a partir da revolução Francesa - e, por outro, a importância atribuída à Constituição pelos homens da época como marco fundante de um novo pacto social entre os poderes soberanos e os súditos - a partir de então considerados cidadãos. Outrossim, destacam a integração entre antigas e novas práticas jurídicas na primeira metade do século XIX, momento em que foram sendo paulatinamente (re)adequados os aparatos jurídicos herdados do período colonial aos novos, constitucionais. Passemos então a cada um desses desenvolvimentos.

Desde a segunda metade do século XVIII as monarquias corporativas europeias tinham suas bases políticas de legitimação questionadas. Particularmente depois de iniciada a Revolução na França, a ideia de que a "nação" era a detentora do poder, ou

\footnotetext{
${ }^{40}$ Idem. Dentre os aparatos e instituições criados, podemos listar a Constituição de 1824 e seu corolários político-institucionais, a lei de responsabilidade dos ministros, as leis de organização das Províncias e Câmaras municipais, o estabelecimento do Superior Tribunal de Justiça, criação do tribunal do júri, a extinção da Mesa de Consciência e Ordens, dentre outros. O Ato Adicional foi o expediente mais significativo no sentido de alterar o status quo da institucionalidade vigente criada na década de 1820 , tocando apenas nas relações entre as províncias e a Corte. Para maiores conhecimentos sobre o relacionamento entre Províncias e a Corte no I Reinado, ver SLEMIAN, Sob o Império das leis. Para aprofundamento na questão das implicações institucionais do Ato Adicional, buscar DOHLNIKOFF, Miriam. O Pacto Imperial. São Paulo: Globo, 2005.

${ }^{41}$ LOPES, José Reinaldo de Lima. Iluminismo e jusnaturalismo no ideário dos juristas da primeira metade do século XIX. In: JANCSÓ, István. Brasil: formação do Estado e da Nação. São Paulo: Hucitec, 2003, p. 195-218.
}

. A constituição moderna. In: BERBEL, Márcia; OLIVEIRA, Cecília Helena de Salles (Orgs.). A experiência constitucional de Cádis. São Paulo: Alameda, 2012, p. 285-309.

. O Direito na História: lições introdutórias. São Paulo: Atlas, 2011.

LOPES, José Reinado de Lima; SLEMIAN, Andrea. A justiça na criação dos Estados ibero-americanos. Experiência comparada Argentina - Brasil - México. In: FONSECA, Ricardo Marcelo (Org.). As formas do Direito. Curitiba: Juruá Editora, 2013.

SLEMIAN, Andrea. A administração da justiça como um problema: de Cádis aos primórdios do Império do Brasil. In: BERBEL, Márcia; OLIVEIRA, Cecília Helena de Salles (Orgs.). A experiência constitucional de Cádis. São Paulo: Alameda, 2012, p. 251-283.

À nação independente, um novo ordenamento jurídico: a criação dos Códigos Criminal e do Processo Penal na primeira década do Império do Brasil. In: RIBEIRO, Gladys Sabina (Org.). Brasileiros e cidadãos. São Paulo: Alameda, 2008, p. 175-206. 
melhor, a ideia da soberania popular, ${ }^{42}$ minou peremptoriamente a soberania dos reis baseada na dinastia e na tradição. Com o aparecimento de um espaço público de críticas e de práticas políticas revolucionárias inéditas, dava-se a sensação aos coevos de estarem vivendo "novos tempos", marcados pela ideia de um porvir diferente e melhor que o passado. ${ }^{43}$ Nesse contexto político marcado pelo ineditismo e por incertezas, a ideia de uma "Constituição" evocada pelos revolucionários franceses ganhou a imagem de "verdadeira pedra de toque, ao fornecer materialidade a anseios de normalização do futuro a partir das experiências de ruptura/continuidade com o passado" ${ }^{44}$. A partir de então, conjugavam-se no continente europeu uma dupla reivindicação dos chamados liberais: por um lado, a busca por um sistema de leis que tornasse pública e visível a ação dos governantes e, por outro, a garantia dos direitos individuais dos cidadãos, tomados por invioláveis pelos revolucionários e, depois, pelas cartas constitucionais da Europa restaurada.

Os impérios coloniais ibéricos não passaram indenes pelo turbilhão revolucionário e suas consequências nos âmbitos político e social, muito embora os desenvolvimentos e experiências constitucionais em cada um dos reinos tenham sido diversos. A despeito de terem trilhado um caminho muito semelhante com as reformas administrativas inspiradas nas "Luzes do século" XVIII - com as chamadas reformas pombalinas em Portugal e bourbônicas na Espanha -, o corolário da guerra napoleônica foi muito diferente para cada uma das Coroas ibéricas.

Na Espanha, o sequestro de Fernando VII levou à acefalia da monarquia e ao aparecimento de juntas governativas, primeiramente em nome do Rei e, posteriormente, em nome da "nação espanhola". A busca por soluções aos problemas políticos advindos da ausência real resultou na convocação de Cortes Constituintes em Cádiz. Tal fato levou ao processo de ruptura em relação às bases de soberania e à própria forma de exercício do governo anteriormente vigentes. ${ }^{45}$ Os desdobramentos desse processo revolucionário, cujo ápice foram os trabalhos constituintes da década de 1810, foram sentidos de maneira radical no território americano, com eleições de juntas nas várias regiões dos vice-reinos espanhóis. Uma vez aberto o caminho da representação e a

\footnotetext{
${ }^{42}$ MERQUIOR, José Guilherme. O repensamento da Revolução. In: FURET, François; OZOUF, Mona. Dicionário Crítico da Revolução Francesa. Rio de Janeiro: Ed. Nova Fronteira, 1989, p. XXXII.

${ }^{43}$ KOSELLECK, Reinhart. .Espaço de experiência e horizonte de expectativa. In: Futuro passado. Rio de Janeiro: PUC/Rio, 2006, p. 305-327.

${ }^{44}$ SLEMIAN, Sob o Império das leis, p. 19.

${ }^{45}$ SLEMIAN, Sob o Império das leis, p. 21.
} 
expectativa de mais autonomia e liberdade, entre elas a econômica, ${ }^{46}$ as elites crioulas da América hispânica passaram a reivindicar mais espaços de poder decisório junto às Cortes, levando a um espiral de conflitos cujo resultado foi sentido nos variados processos de independência da região. A Constituição de Cádiz de 1812, no entanto, legou uma profícua herança ao mundo ibérico, impactando não somente as constituições das ex-colônias como também servindo de aprendizado político e tornando-se espaço de experiência importante para as Cortes portuguesas de 1820, para a Assembleia Constituinte de 1823 no Brasil e também para a Constituição imperial de $1824{ }^{47}$

Já o que se passou com a vinda da Corte lusa para suas possessões americanas levou a desenvolvimentos históricos diversos àqueles do império espanhol. Fato inédito na história europeia, foi também movimento de inflexão sem paralelo para a América portuguesa.

A situação do então regente d. João em sua colônia o influenciou de maneira decisiva a realizar as reformas que muitos de seus súditos americanos ansiavam, particularmente aqueles ligados ao grande comércio marítimo, os chamados "homens de grosso trato". Já em 1808 foi liberado o comércio com todas as "nações amigas" em todos os portos americanos e, dois anos depois, estabelecido o tratado de Comércio e Navegação com a Inglaterra, designando taxas preferenciais para produtos ingleses. A liberalização dos portos, ao destituir o exclusivo metropolitano, galgou as porções americanas do Império a uma posição mais importante que sua congênere europeia, fato admitido no período por importantes ministros de d. João, entre eles d. Rodrigo de Sousa Coutinho.

Em 1815, por ocasião de sua coroação, d. João elevou o Brasil a Reino Unido de Portugal, fato político de não pouca monta. Além de parear politicamente o Brasil a Portugal e a Algarves, teve grandes implicações à formação identitária brasileira. ${ }^{48}$ Segundo István Jancsó e João Paulo Pimenta:

\footnotetext{
${ }^{46}$ DONGHI, Túlio Halperin. História da América Latina. São Paulo: Editora Paz e Terra, 2011, p. 5595.

${ }^{47}$ BERBEL, Márcia; FERREIRA, Paula Botafogo C. Soberanias em questão: apropriações portuguesas sobre um debate iniciado em Cádis; CALERO, Manuel Chust. As Cortes de Cádis, a Constituição de 1812 e sua transcendência americana; OLIVEIRA, Cecília Helena de Salles, A Carta de 1824 e o poder do monarca: memórias e controvérsias em torno da construção do governo constitucional no Brasil; SLEMIAN, Andrea. A administração da justiça como um problema: de Cádis aos primórdios do Império do Brasil; todos In: BERBEL, Márcia; OLIVEIRA, Cecília Helena de Salles (Orgs.). A experiência constitucional de Cádis. São Paulo: Alameda, 2012.

${ }^{48}$ JANCSÓ, István; PIMENTA, João Paulo. Peças de um mosaico (ou apontamentos para o estudo da emergência da identidade nacional brasileira, p. 154.
} 


\begin{abstract}
A condição americana (sic), que no período anterior expressava apenas um predicado genérico que distinguia portugueses da Bahia ou de São Paulo dos de Portugal, encontrou no recém-criado reino do Brasil a referência palpável da sua politização. O novo reino transformara (...) um conglomerado de capitanias atadas pela subordinação ao poder de um mesmo príncipe numa entidade política dotada de precisa territorialidade e de um centro gravidade (...). A partir de então a anterior identidade luso-americana (sic) poderia tornar-se brasileira e como tal se autonomizar (...). ${ }^{49}$
\end{abstract}

Ao se levar em conta tais considerações, o ato de elevação não foi simples formalidade simbólica. A partir dele foi possível pensar em uma identidade brasileira que se consolidaria somente a partir da segunda metade do século XIX -, sendo, portanto, elemento importante para o processo de autonomização que adviria menos de uma década depois.

Esses eventos, somados às demais transformações no período, ${ }^{50}$ lançaram por terra definitivamente o estatuto colonial da América portuguesa. Essa situação de inversão do antigo nexo colonial levou a grandes descontentamentos no reino europeu: "Havia uma impressão generalizada de que Portugal estava órfão, sem seu rei, e que o epicentro do Império residia no Rio de Janeiro". 51

A situação no reino europeu deteriorou-se rapidamente a partir do momento em que d. João decidiu permanecer no Rio de Janeiro mesmo depois de findas as guerras e o governo napoleônico. O governo passou a ter sua legitimidade questionada, de que são exemplos claros as insurreições de 1817 ocorridas em Pernambuco e em Portugal, e a pressão para a realização de mudanças políticas aumentou crescentemente no período. Aos fatores internos à administração do império luso-brasileiro, outros externos se somaram. Vários reinos europeus estavam adotando constituições escritas que regulavam os poderes reais e permitiam maior participação dos súditos - ainda que de maneira não muito ampla - na administração do governo: a França outorgava sua Carta em 1814 e os chamados liberais da Espanha lutavam num vai-e-vem para manter a Constituição aprovada em Cádiz. ${ }^{52}$ Além dessas experiências europeias, encontra-se ainda o exemplo da América do Norte e das independências hispano-americanas, mais

\footnotetext{
${ }^{49}$ Ibidem, p. 154-155.

${ }^{50}$ Como, por exemplo, a criação da Imprensa Régia e da Academia Real Militar, a fundação do Banco do Brasil e a liberação para construção de manufaturas, além da fundação de escoladas de Medicina na Bahia e no Rio de Janeiro.

${ }^{51}$ SOUZA, Iara Lis Carvalho de. Pátria Coroada, p. 58.

52 Interessante é notar, como o fez René Rémond, que o movimento de Restauração, epitomizado no Congresso de Viena, não significou o retorno ao passado por completo, resultando em concessões importantes por parte daqueles que eram restaurados aos tronos europeus, particularmente a outorga de Constituições em vários reinos. Cf. RÉMOND, René. O século XIX. São Paulo: Editora Cultrix, 1990, p. 21.
} 
radicais pela escolha da república como forma de governo com um sistema mais direto na eleição dos governantes. No entanto, o governo joanino resistiu ao ímpeto de mudança, acirrando as tensões que acabaram por estourar sob a forma de uma revolução a partir da cidade do Porto. Esse movimento revolucionário rapidamente tomou conta de Portugal e substituiu a Regência por um novo governo cuja prioridade era a convocação das Cortes para a formulação de uma Constituição.

Uma das preocupações dos revolucionários era a de não atrair a atenção e o furor da Santa Aliança e evitar que a intervenção dos países que compunham essa "liga" viesse a frustrar os planos de estabelecer um reino constitucional. ${ }^{53}$ Nesse sentido, defendiam que as propostas de convocação das Cortes correspondessem a anseios de retomar as tarefas que esse ambiente político possuíra antes, autorrepresentando as Cortes vintistas como herdeiras das Cortes de Lamego e daquelas que escolheram o duque de Bragança rei de Portugal em 1640. Ao se colocarem na linhagem dessas antigas reuniões de aclamação, os revolucionários inseriam o vintismo na tradição portuguesa e acalentavam os ânimos das demais potências europeias. Por outro lado, ao fazê-lo, destacavam que o monarca havia sido escolhido pelo "povo" - entendido como os partícipes da sociedade política - e formado um pacto com ele. Assim sendo, o poder e o direito pertenciam em primícias ao povo e não ao rei, podendo aquele, frente ao descumprimento do pacto pela parte do soberano, retomá-los e refundar a sociedade sob novas bases políticas, sob novas leis fundamentais. ${ }^{54}$

Essa noção jusnaturalista contratualista tomou contornos revolucionários ${ }^{55}$ no vintismo na medida em que sua proposta subvertia a ordem então existente, reconstruindo sobre novas bases os edifícios político-sociais. Não obstante, ao inserir-se na história portuguesa como continuadora das Cortes pregressas, podia se autointitular "Regeneração de 1820". Tal entrelaçamento entre os eventos pretéritos e aqueles da

\footnotetext{
${ }^{53}$ Algo que veio a acontecer com a Espanha três anos depois, com a invasão do exército francês para sufocar o movimento liberal Cf. HOLROYD, Richard. The Bourbon Army, 1815-1830. The Historical Journal, vol. 14, n. 3 (Sep., 1971), p. 529-552.

${ }^{54}$ SOUZA, Iara Lis Carvalho de. Pátria Coroada, p. 77.

${ }^{55}$ É importante delimitar o uso do termo "revolucionário" e "Revolução" empregados aqui para evitar equívocos, uma vez que durante o período trabalhado este conceito passou por transformações semânticas. Entende-se por Revolução: "mudanças extraordinárias sobrevindas nos negócios públicos, os reveses de sorte das nações. Não se trata mais de um retorno do mesmo ao mesmo, mas do aparecimento, brusco e violento, da novidade. O caráter previsível, a desordem a ordem, o extraordinário o ordinário", significado que se estabeleceu como lugar-comum a partir da Revolução Francesa. Por revolucionário entende-se o grupo agente da Revolução. Cf. OZOUF, Mona. Revolução. In: FURET, François; OZOUF, Mona. Dicionário Crítico da Revolução Francesa. Rio de Janeiro: Ed. Nova Fronteira, 1989, p. 841. Para um estudo mais aprofundado sobre o intricamento temporal contido no conceito ver KOSELLECK, Reinhart. Critérios históricos do conceito moderno de revolução. In: Futuro Passado. Rio de Janeiro: PUC/Rio, 2006, p. 61-77.
} 
década de 1820 indicam o nascimento de um novo tempo histórico que já havia dado mostras no continente europeu a partir da irrupção revolucionária francesa, como mencionado anteriormente. Os vintistas atualizaram as experiências das Cortes medievais para legitimar seu movimento, ao mesmo tempo em que objetivavam primordialmente romper com os tradicionais alicerces de sustentação do poder em busca de um novo governo assentado em fundamentos constitucionais. Assim, seu espaço de experiência circunscrito das Cortes de Lamego, de caráter pactista, informava um presente revolucionário cujo anseio era por um futuro diferente e, em sua perspectiva, melhor.

Esse novo nexo temporal permitiria a esses homens, e seus congêneres americanos, ${ }^{56}$ pensar outras saídas para os desafios que se apresentavam em fórmulas distintas daquelas do passado, abrindo o caminho para a mudança e o inaudito. Por outro lado, essa série de transformações rápidas precisou ser articulada na linguagem pelas pessoas que a viviam. Como, no entanto, o vocabulário existente não é infinito para demarcar todas as experiências humanas, alguns conceitos foram rearticulados linguisticamente para dar conta dessas alterações político-sociais, resultando numa polissemia profícua nesse período de grandes instabilidades. ${ }^{57}$ Assim se procedeu com conceitos como "cidadania", "soberania", "nação", "pátria", 58 entre outros, legando em cada um deles um imbricamento temporal que apontava, a depender dos grupos que os utilizassem, para experiências do passado e expectativas de futuro diferentes. Esse duplo aspecto - de um novo tempo histórico e de ressignificação de conceitos impactou de maneira profunda os "portugueses da América" e estiveram no pano de fundo das transformações que advieram logo após o movimento de 1820.

Uma vez vitorioso, o grupo revolucionário tratou de buscar apoio nas terras americanas e evitar um confronto imediato e duro com d. João. Tão logo foram divulgadas as notícias nas diversas regiões do reino, as províncias do Pará e da Bahia aderiram às Cortes e as reconheceram como órgão governante e a quem deviam obediência. Em seguida, todas as demais partes do Brasil seguiram a jurar às Cortes, primeiramente o Nordeste e posteriormente o Centro-Sul. A perspectiva de se refazer o contrato entre soberano e súditos e entre as partes do Império animava as elites luso-

\footnotetext{
${ }^{56}$ ARAUJO, Valdei Lopes de. A experiência do tempo: Conceitos e Narrativas na Formação Nacional Brasileira (1813-1845). São Paulo: Hucitec, 2008.

${ }^{57}$ KOSELLECK, Reinhart. Linguistic change and the history of events. The Journal of Modern History, vol. 61, n. 4 (Dez.), 1989, p. 649-666.

${ }^{58}$ NEVES, Corcundas e constitucionais, p. 169-198.
} 
brasileiras. Rapidamente foram formadas as Juntas Provisórias de Governo nas províncias da América e realizadas eleições para a escolha dos representantes do Brasil nas Cortes. Encurralado politicamente, d. João foi então forçado a jurar as Bases da Constituição Portuguesa, a aceitar a constituição a ser feita e a retornar a Portugal. Sem opção, o rei partiu, mas deixou seu filho mais velho como Regente, à revelia da determinação das Cortes. ${ }^{59}$ Começava então um processo cujo desenlace levaria à cesura entre os "portugueses dos dois lados do Atlântico".

Os anos de 1821-1822 foram repletos de tensão no Império Português. A existência de dois espaços políticos que rivalizavam entre si levou progressivamente à deterioração dos laços que até então haviam mantido Brasil e Portugal unidos. Os trabalhos legislativos das Cortes ao invés de estancar os problemas os fizeram tomar maiores proporções, pelo caráter próprio do ambiente de discussões que é o Parlamento e pela gravidade das matérias em jogo. Por outro lado, à medida que as discussões parlamentares antagonizavam cada vez mais os interesses americanos daqueles dos europeus, os posicionamentos dos deputados do Brasil tenderam a se aglutinar - ainda que não deixassem de existir diferenças entre eles - formando uma espécie de "bancada brasileira", aprofundando e delineando com mais força a unidade que a elevação do Brasil a Reino Unido já havia iniciado cinco anos antes. ${ }^{60}$ Outrossim, a permanência do príncipe real no Rio de Janeiro fortaleceu a noção de um centro de poder dentro da América que se apresentava como polo gravitacional das demais províncias. Desse modo, no interior da Corte brasileira surgia um projeto político diverso àquele das Cortes e que tinha em d. Pedro seu símbolo. ${ }^{61}$

Se ao longo dos anos de 1821 e 1822 o projeto de refundação do pacto entre Portugal e Brasil sob a base da união do império perdia cada vez mais força e viabilidade pelas contradições internas apresentadas, tornava-se cada vez mais factível a fundação de um novo Estado nas terras brasileiras. Discutia-se esse futuro aberto nos jornais, panfletos, reuniões maçônicas, nas ruas e praças, nos círculos palacianos. Vários grupos letrados apresentavam suas ideias e concepções políticas para o novo contrato que havia de se celebrar, buscando alinhavar os interesses das localidades e províncias do Norte-Nordeste com aqueles do Centro-sul que se arrogavam liderança e hegemonia.

\footnotetext{
${ }^{59}$ SOUZA, Pátria Coroada, p. 96.

${ }^{60}$ JANCSÓ; PIMENTA. Peças de um mosaico (ou apontamentos para o estudo da emergência da identidade nacional brasileira), p. 167.

${ }^{61}$ Iara Lis de Souza cunhou a expressão "Imperador-contrato" para se referir ao papel que d. Pedro, ou melhor, sua persona, teria como aglutinador desse processo e referência para as elites luso-brasileiras na busca de realização de seus projetos. SOUZA, Pátria Coroada, p. 107.
} 
Esse projeto ganhou mais força com a convocação em junho de 1822 de uma Assembleia Constituinte no Brasil.

Os contínuos impasses entre as Cortes e o grupo político encabeçado pelo Regente acabaram por levar à separação definitiva entre ambas as unidades políticas. Cortados os laços e encetada a guerra de independência, iniciava-se o processo de construção do Estado que se passou a chamar de Império do Brasil.

\subsection{Novo Estado, novo Cidadão}

$\mathrm{Na}$ esteira dos eventos que levaram ao corte dos laços políticos entre Portugal e Brasil, a Assembleia Constituinte convocada pouco tempo antes ganhou nova e maior importância, por se tornar o primeiro espaço de discussão e deliberação em território brasileiro e com a missão, inédita, de preparar uma constituição para o Estado recémcriado. Seguindo as orientações expedidas pelo governo do Regente, foram realizadas eleições nas mais diversas partes do Brasil para a escolha dos deputados constituintes. Estes começaram a se reunir na Corte do então país independente em abril de 1823 para organizar os trabalhos que se iniciariam em maio. Embora a Assembleia Constituinte não tenha finalizado seu propósito nem durado muito tempo - funcionou de maio a novembro até o fechamento ordenado por d. Pedro -, teve fundamental importância na organização das bases constitucionais do Império, influenciou decisivamente a Carta de 1824 e manteve em circulação ideias e práticas políticas modernas, colocando em disputa parlamentária noções e conceitos que já passavam por ressignificações no ambiente político europeu desde fins do século XVIII. Uma ampla bibliografia sobre o tema já abordou os pontos nevrálgicos da Assembleia, suas principais discussões e seu legado. ${ }^{62}$ Aqui se pretende apresentar as questões relativas à consecução de um novo

\footnotetext{
${ }^{62}$ Entre alguns dos numerosos estudos, pode-se citar:

BARMAN, The forging of a Nation, p. 97-129.

GRINBERG, $O$ fiador dos Brasileiros.

PEREIRA, Ao Soberano Congresso.

SLEMIAN, Andrea. Seriam todos Cidadãos? In: JANCSÓ, István. Independência: história e historiografia. São Paulo: Hucitec, 2005, p. 829-880.

À nação independente, um novo ordenamento jurídico: a criação dos Códigos Criminal e do Processo Penal na primeira década do Império do Brasil. In: RIBEIRO, Gladys Sabina (Org.). Brasileiros e cidadãos. São Paulo: Alameda, 2008.
}

Sob o Império das Leis.

SOUZA, Pátria Coroada. 
Pacto Social anunciado pela Constituinte, sintetizado na Constituição de 1824 e debatido na Assembleia de 1826.

A ideia de que se fundava uma nova sociedade por meio de novo pacto social transparecia claramente na Constituinte desde suas primeiras sessões. Esse pacto estabeleceria as leis fundamentais do país a partir das quais todas as demais relações político-sociais se derivariam. Nesse sentido, entravam em disputa no campo político diferentes entendimentos sobre a divisão dos poderes, o direito, a cidadania e a soberania. $^{63}$

Nas primeiras sessões preparatórias da Constituinte, os deputados enfrentavam uma questão cerimonial de prolífico significado político - que se repetiria de maneira semelhante na abertura da Assembleia Geral três anos depois. Discutiam acerca da entrada do Imperador quando da abertura dos trabalhos legislativos, em particular onde o imperador deveria se sentar na Casa legislativa e como entraria no recinto: sentar-se-ia ao lado do presidente da casa ou um nível acima? Entraria com ou sem sua regalia ${ }^{64}$ ? José Custódio Dias, deputado por Minas Gerais, defendia que

É na solene instalação destas [Cortes] que tem de comparecer o Digno Representante do Poder Executivo, e como tal tenha de respeitar a Nação legitimamente representada da qual só deriva toda a autoridade que pelo Pacto Social se lhe vai a conferir por lei fundamental, sou de parecer que a posição que se lhe deve designar seja sim distinta, mas no mesmo plano onde estiver o Sr. Presidente, cabeça inseparável, naquele ato, ao Corpo Moral que representa a Nação, Soberana independente, e deixaria de o ser quando tivesse superior. $^{65}$

Imperador e presidente da Câmara estariam, portanto, no mesmo nível porque representariam de maneira igual a Nação. Outrossim, somente a partir de estabelecido o novo pacto pela Assembleia é que se derivaria a autoridade do monarca. Assim sendo, Dias colocava ênfase no poder da Assembleia frente ao do Imperador. Contra essa argumentação logo em seguida se pronunciou Andrada Machado: ${ }^{66}$

Já desde a segunda metade do século XIX alguns homens públicos debateram o papel e legado da Assembleia, como Homem de Mello e José de Alencar. Cf. BRASIL. A Constituinte de 1823. Brasília: Senado Federal, 1973.

${ }^{63}$ PEREIRA, Ao Soberano Congresso.

${ }^{64}$ Utiliza-se aqui o termo latino referente às insígnias características do soberano. Provém do adjetivo regalis derivado de rex, que significa "rei". No caso específico dessa cerimônia de entrada, referia-se ao cetro, ao manto e à Coroa.

65 BRASIL. Diário da Assembleia Geral, Constituinte e Legislativa do Império do Brasil (DAC). Brasília: Senado Federal, 2003, terceira sessão preparatória de 30 de abril, tomo I, p. 5.

${ }^{66}$ Natural de São Paulo nasceu em Santos em 1 de novembro de 1773 e faleceu no Rio de Janeiro em 5 de dezembro de 1845. Formado em direito pela universidade de Coimbra, seguiu a carreira da magistratura, que estreou exercendo o cargo de juiz de fora de Santos, depois o de ouvidor de Olinda. Em 1817, achando-se no exercício deste cargo, aderiu à revolução de Pernambuco, fazendo parte de seu conselho. 
Que paridade há entre o Representante Hereditário da Nação inteira e os Representantes temporários? Ainda mais que paridade há entre o Representante Hereditário e um único Representante temporário, que, em que condecorado com o título de Presidente, não é mais que o primeiro entre os seus iguais? Que paralelo pode encontrar-se entre o Monarca que em sua individualidade concentra toda uma delegação soberana, e o Presidente de uma Assembleia que abrange coletivamente outra delegação soberana, mas que não deve nem pode abrangê-la toda? (...) Enfim Sr. Presidente nada pode haver de comum em hierarquia e precedência entre o Monarca que para bem dos povos tem a Lei, por uma ficção legal, posto além da esfera da humanidade, e quase endeusado, e um puro mortal que, apesar de respeitável, é sujeito às mesmas Leis, que regem tais Membros da Sociedade? ${ }^{67}$

Finda a discussão, foi aprovado que o Presidente se sentaria à direita do Imperador um nível abaixo dele. Continuando a votação do regulamento, chegou-se na discussão do artigo 27 que dizia que o Imperador deveria entrar descoberto, ou seja, sem a Coroa na cabeça. Lido o texto, imediatamente se pronunciou Carneiro de Campos ${ }^{68}$ contrário à matéria, afirmando que indo o Imperador instalar a Assembleia como Chefe da Nação e sendo a Coroa sua insígnia, tanto quanto o manto e o cetro, ele deveria ir coberto, não devendo ser privado de seus símbolos. ${ }^{69}$ Carneiro de Campos não conseguiu seu intento nessa votação - que decidiu que seus símbolos entrariam carregados atrás deles por seus oficiais -, mas já depois de instalada a Constituinte, voltaria ao assunto e conseguiria convencer seus colegas, os quais estabeleceram que o monarca deveria ir com toda sua regalia nas demais aberturas. ${ }^{70}$

$\mathrm{O}$ que nos mostram essas discussões que hoje poderiam ser consideradas bizantinas? Elas apontam para vários conflitos que surgiam nesse momento fundacional do Estado brasileiro, particularmente o referente à separação, à acomodação e à articulação dos poderes numa base constitucional, ou seja, "[a]o enquadramento da monarquia em uma nova base de legitimidade". ${ }^{71}$ Esse enquadramento necessariamente passava por um novo entendimento sobre quem compunha a nação, quem poderia representá-la e quem detinha a soberania.

Foi preso e levado para a Bahia, até que lhe foi concedida a anistia pelas Cortes portuguesas, sendo eleito para estas em 1821 pela província de São Paulo. Na Constituinte brasileira, foi relator da comissão que apresentou o projeto de constituição.

${ }^{67}$ DAC, terceira sessão preparatória de 30 de abril, tomo I, p. 5.

${ }^{68}$ Visconde e depois Marquês de Caravelas, nasceu na cidade da Bahia em 4 de março de 1768 e faleceu no Rio de Janeiro em 8 de setembro de 1836. Foi deputado pelo Rio de Janeiro na Constituinte brasileira e eleito senador na fundação do Senado ao mesmo tempo por S. Paulo, pela Bahia e pelo Rio de Janeiro. Por ocasião da abdicação de dom Pedro I, foi um dos três membros da Assembleia eleitos para regentes do império. Participou da escrita da Constituição outorgada como membro do Conselho de Estado.

${ }^{69}$ DAC, terceira sessão preparatória de 30 de abril, tomo I, p. 7.

${ }^{70}$ DAC, sessões de 11/06 e 12/06, tomo I, p. 199-216.

${ }^{71}$ SLEMIAN, Sob o império das Leis, p. 88. 
O conceito de nação foi bastante ressignificado nesse período - tanto no Brasil quanto no cenário europeu - e foco de atenção e disputas no âmbito político pelas consequências que sua definição trazia. Em fins do século XVIII, o termo "nação" estava associado ao de ordem política e significava, de acordo com o Dicionário de Rafael Bluteau de 1716:

Nome coletivo, que se diz da gente que vive em alguma grande região ou Reino, debaixo do mesmo Senhorio (...) nisso se diferencia nação de povo, porque nação compreende muitos povos e assim Beirões, Minhotos, Alentejões etc. compõem a nação Portuguesa. ${ }^{72}$

A ênfase no Senhorio dessa definição valorizava sobremaneira o Estado ao qual pertenciam os povos, ainda que se levasse em consideração a língua e o território. Ao longo do século XVIII, particularmente depois da Revolução na França, esse significado foi perdendo cada vez mais força para uma outra definiçãa, qual seja, de que nação se referia a um determinado "corpo de cidadãos". ${ }^{73}$ Essa conceituação passou a ser hegemônica no mundo luso-brasileiro a partir do vintismo e se estabeleceu como tal no Império. Assim, a nação não se referia a todos de um Estado, somente aos que

Eran ciudadanos, a los que gozaban de derechos y privilegios en algún foro, a los que habitaban ciudades o villas y, en suma, a los que, por encontrarse en esta condición, como pertenecientes a una particular "vizinhança”, o como parte de un determinado "corpo de cidadãos", pasaban a poder reivindicar su representación en la nación moderna que se afirmaba. ${ }^{74}$

Essa compreensão da nação como corpo de cidadãos desenvolveu-se como corolário da emergência da noção de indivíduo na sociedade, algo que Hespanha chamou de "paradigma individualista" 75 Foi essa concepção que permitiu nascer, inclusive, a ideia de uma ordem social fundada a partir de um contrato ou de um pacto baseado nas "vontades" dos indivíduos e não mais em uma ordem natural ou divina das coisas, e, portanto, influenciou de maneira decisiva todos os processos políticos ulteriores.

Ora, se nação passava a compreender o corpo de cidadãos, quem era cidadão no Império? Para responder, iniciemos pela compreensão coeva, suas variações entre fins

\footnotetext{
72 Apud PAMPLONA, Marco Antonio Villela. Nación - Brasil. In: SEBASTIÁN, Javier Fernández; LOMNÉ, Georges (Orgs.). Diccionario politico y social del mundo iberoamericano. Iberconceptos - II. .Madrid: Universidade del País Vasco y Centro de Estudios Políticos y Constitucionales - Min de la Presidencia, 2014, v. 2, p. 882.

${ }^{73}$ Ibidem, p. 885.

${ }^{74}$ Idem.

${ }^{75}$ HESPANHA, António Manuel; XAVIER, Ângela Barreto. A representação da sociedade e do Poder. In: HESPANHA, António Manuel (coord.). História de Portugal: Antigo Regime. Lisboa: Editorial Estampa, 1993, p. 125.
} 
do século XVIII e início do século XIX e o uso político feito do conceito, principalmente na Constituinte e depois da abertura da Assembleia Geral.

Um bom caminho para se adentrar esse complexo esquema mental de apropriações e significações conceituais é o debate do projeto de constituição apresentado em setembro de 1823. Em debate acerca do artigo que definia quem eram os "brasileiros", discursou Pedro Araújo Lima: ${ }^{76}$

\begin{abstract}
Na língua portuguesa donde derivamos a nossa, bem como na espanhola, a palavra Cidadão tem uma significação mui particular, ela designava o morador ou vizinho da Cidade. Sabe-se que pelo Direito Feudal, as povoações, segundo que eram Cidades, Vilas, ou lugares, tinham assim diferentes direitos, gozavam certos privilégios, liberdades e isenções. Isto era muito importante naquele tempo; e a palavra Cidadão designava como já disse, o morador ou vizinho da Cidade, o qual por isso gozava diferentes direitos que não se estendiam a todos os Membros da sociedade. (...) isto, porém, acabou, e, portanto, deve ser extensa essa denominação a todos os indivíduos, porque seria odioso que conservássemos uma diferença que traz sua origem de tempos tão bárbaros, e que é fundada naqueles diferentes privilégios (...). ${ }^{77}$
\end{abstract}

Essa definição de cidadão feita pelo deputado, contudo, ainda não se encontrava em alguns dicionários da época. O Dicionário da Língua Portugueza de 1823, caracterizava cidadão como "o homem que goza dos direitos de alguma cidade, das isenções e privilégios que se contém no seu foral, posturas (....); o vizinho de alguma cidade; (...) o homem bom". ${ }^{78}$ Em outro dicionário de treze anos depois - o Novo Dicionário Crítico e Etymologico da Lingua Portugueza - encontrava-se a definição de cidadão como alguém "apto para os cargos municipais". 79

Esses significados remetiam ainda às formas antigas de cidadania de fundo socialmente hierárquico de base corporativa ligada ao que se convencionou chamar de

\footnotetext{
${ }^{76}$ Visconde e depois Marquês de Olinda nasceu em Pernambuco em 22 de dezembro de 1793 e faleceu no Rio de Janeiro em 7 de junho de 1870, doutor em cânones pela universidade de Coimbra, senador do Império, conselheiro de estado, sócio fundador do Instituto histórico e geográfico brasileiro, oficial da ordem do Cruzeiro, grã-cruz da ordem de Christo e das ordens francesa da Legião de Honra, turca de Medjidié, sarda de S. Maurício e S. Lázaro, húngara de Santo Estevam e mexicana de N. S. de Guadalupe. Foi deputado nas Cortes portuguesas, na Constituinte brasileira e nas primeiras legislaturas. Escolhido senador em 5 de setembro de 1837 pelo regente Feijó e logo nomeado ministro do Império, retirando-se aquele do poder, assumiu a regência do Império em 19 de setembro, cargo que ocupou até a maioridade de d. Pedro II.

${ }_{77}^{77}$ DAC, sessão de 24 de setembro, tomo III, p. 106.

${ }^{78}$ Apud SANTOS, Beatriz Catão; FERREIRA, Bernardo. Ciudadano - Brasil. In: SEBASTIÁN, Javier Fernández; LOMNÉ, Georges (Orgs.). Diccionario politico y social del mundo iberoamericano. Iberconceptos - II. .Madrid: Universidad del País Vasco y Centro de Estudios Políticos y Constitucionales - Min de la Presidencia, 2014, v. 2, p. 211.

${ }^{79}$ Idem.
} 
Antigo Regime, ${ }^{80}$ que Araújo Lima remetia como ultrapassado. A complexidade que assumia o termo no Brasil independente refere-se ao estatuto colonial que vigorara até pouco tempo antes e cujo aspecto marcante era a escravidão. A associação entre cidadania e as prerrogativas de "vizinhança" demarcava uma lógica segundo a qual a integração do indivíduo na sociedade política se concebia baseada em privilégios, entre eles o de participar da administração da res publica. ${ }^{81}$ Os cidadãos com direito de vizinhança na colônia eram os "homens bons", homens com "pureza de sangue" - sem ascendência judaica, mourisca, negra, indígena - e que não exerciam ofícios mecânicos. O cidadão muito se aproximava do estatuto do nobre, que na colônia buscava ser reconhecido como "homem principal" ou "principal da terra". ${ }^{82}$ Nesse sentido, pode-se afirmar que os cidadãos não se confundiam com o restante da população.

Esse estatuto de cidadão começou a se modificar na medida em que as próprias noções corporativas de sociedade que o embasavam começaram a ruir. Com a ascensão da ideia de indivíduo portador de direitos ao longo do século XVIII, difundiram-se as concepções de direitos subjetivos e de soberania popular, ambas tributárias do jusnaturalismo contratualista. A possibilidade de que o ideal de uma cidadania igualitária - que adquiriu contornos radicais no período do Terror francês - se consolidasse assustava as elites coloniais luso-brasileiras dos séculos XVIII e XIX, uma vez que pudesse inflamar os ânimos a favor da abolição da escravatura e da igualdade de cor - bandeira que a chamada Conjuração Baiana de 1798 empunhou e que remetia claramente aos acontecimentos da ilha de São Domingos de $1791 .^{83}$ É com esse clima de acirrada disputa e preocupação com as tensões sociais e raciais que o debate na Constituinte se dava e por isso a definição mais ampla ou mais restrita da cidadania e seus direitos estava na ordem do dia para aqueles homens.

Na consecução do novo pacto social que se anunciava, era necessário, portanto, redefinir quem seria considerado membro da nova nação e quem não seria. No caso brasileiro, isso assumiu tons dramáticos porque passou, em primeiro lugar, pela

\footnotetext{
${ }^{80}$ A expressão Antigo Regime também foi objeto de múltiplas interpretações entre fins do século XVIII e o início do século XIX. Para o trabalho aqui apresentado, refere-se à monarquia absoluta e à sociedade de ordens com seus correlatos traços mentais, costumes e hábitos. Cf. FURET, François. Antigo Regime. In: FURET, François; OZOUF, Mona. Dicionário Crítico da Revolução Francesa. Rio de Janeiro: Ed. Nova Fronteira, 1989, p. 621-632.

${ }^{81}$ SANTOS; FERREIRA. Ciudadano - Brasil, p. 212.

${ }^{82}$ BICALHO, Maria Fernanda Baptista. O que significava ser cidadão nos tempos coloniais. In: ABREU, Martha; SOIHET, Rachel (Orgs.). Ensino de história: conceitos, temáticas e metodologia. Rio de Janeiro: Casa da Palavra, 2003, p. 143-145.

${ }^{83}$ SANTOS; FERREIRA. Ciudadano - Brasil, p. 215.
} 
separação entre o "português" e o "brasileiro", grupos identitários que até o momento da separação política não eram opostos ou mesmo muito diferentes. A saída encontrada pela classe política reunida na Constituinte foi a da adesão à nova sociedade, remontando à ideia de contrato. Como argumentou o deputado José Martiniano de Alencar:

... acho desnecessário fazer aqui diferença de nascidos em Portugal e nascidos no Brasil, ou em outra qualquer parte da Monarquia Portuguesa; porque tanto é Cidadão Brasileiro o nascido em Portugal, como o nascido no Brasil, contanto que entrassem de princípio no novo Pacto Social, isto é, que reconhecessem, proclamassem e aderissem à Causa da Independência. ${ }^{84}$

Essa lógica de aderir à causa da Independência ficou marcada na Carta imperial de 1824 em seu artigo sexto, inciso IV:

[são cidadãos brasileiros] Todos os nascidos em Portugal e suas possessões que já sendo residentes no Brasil à época em que se proclamou a independência nas Províncias onde habitavam aderiram a esta expressa ou tacitamente pela continuação de sua residência. ${ }^{85}$

O mesmo princípio de adesão marcaria as linhas internas dos direitos do cidadão no Império, em oposição àqueles "inimigos” que habitavam o território brasileiro, isto é, escravos e índios. ${ }^{86}$ Aqueles que não possuíam liberdade - característica por excelência do escravo - não poderiam aderir a pacto algum, porque não eram donos de si. Por outro lado, os indígenas, ainda que livres, não reconheciam as autoridades do país e, portanto, não poderiam adentrar o novo corpo político. Como deixou bastante claro o deputado Montezuma: ${ }^{87}$

... falamos aqui dos Súditos do Império do Brasil, únicos que gozam dos cômodos de nossa Sociedade e sofrem seus incômodos, que têm direitos e obrigações no Pacto Social, na Constituição do Estado. Os índios porém

\footnotetext{
${ }^{84}$ DAC, sessão de 26 de setembro, tomo III, p. 118.

85 BRASIL. Constituição Política do Império do Brasil. Disponível em: <http://www.planalto.gov.br/ccivil_03/constituicao/Constituicao24.htm>. Acesso em: 16/06/2014, às 19:00.

A adesão expressa à Independência se realizou por meio do juramento à Constituição feita nas câmaras municipais nas diversas localidades do Império. Cf. SLEMIAN, Sob o Império das leis.

${ }^{86}$ SLEMIAN, Seriam todos cidadãos?.

${ }^{87}$ Visconde de Jequitinhonha, nascido na cidade da Bahia em 23 de março de 1794, chamou-se, até ser proclamada a independência do Brasil, Francisco Gomes Brandão Montezuma, e faleceu no Rio de Janeiro em 15 de fevereiro de 1870. Foi bacharel em leis pela universidade de Coimbra, grande do império, senador por sua província natal, conselheiro de estado, dignitário da ordem da Rosa, comendador da ordem portuguesa da Conceição de Vila Viçosa, condecorado com a medalha da guerra da Independência, fundador e presidente honorário do Instituto da ordem dos advogados brasileiros, de que foi o primeiro presidente efetivo, sócio do Instituto histórico e geográfico brasileiro, da sociedade Auxiliadora da indústria nacional. Foi deputado na constituinte brasileira e deputado na quarta legislatura, pugnou pela maioridade de D. Pedro II. No gabinete de 16 de maio de 1837, o ultimo da regência Feijó, ocupou a pasta dos estrangeiros e, interinamente, a da justiça.
} 
estão fora do grêmio de nossa Sociedade, não são súditos do Império, não o reconhecem (...) não podem de forma alguma ter direitos, porque não têm nem reconhecem deveres ainda os mais simples (falo dos não domesticados): como considerá-los Cidadãos Brasileiros? (...) Enquanto aos crioulos cativos (...) havemos de confessar que não entram na classe dos Cidadãos, que não são membros de nossa política Comunhão e, portanto, não são Brasileiros no sentido próprio, técnico das Disposições Políticas. São homens para não serem tiranizados, mas (...) quanto ao exercício de direitos na sociedade são considerados coisa ou propriedade de alguém; como tais as Leis os tratam e reconhecem. Logo: como chamá-los Brasileiros no sentido próprio? (...) Seria mister considerá-los membros da Sociedade Brasílica: mas este nome só pode competir e só tem competido a homens livres... ${ }^{88}$

Entre as pessoas livres e os cativos, contudo, havia um grupo de pessoas com os quais os deputados precisavam lidar: os libertos. A discussão em torno da questão se os libertos poderiam ter acesso à cidadania foi bastante acalorada e dividiu as opiniões dos constituintes. A polêmica iniciou-se porque o artigo presente no projeto de Constituição era bastante amplo: seriam considerados cidadãos brasileiros todos os "escravos que obtivessem carta de alforria". ${ }^{89}$ Assim que entrou em discussão plenária, o deputado Souza França opinou contrariamente à forma redigida porque, para ele, somente poderiam receber os direitos de cidadão os libertos nascidos no Brasil. Os libertos africanos não poderiam ser cidadãos porque eram estrangeiros. ${ }^{90}$ De acordo com Slemian, a questão de fundo era civilizacional, como colocou o deputado Manuel Caetano de Almeida e Albuquerque:

... como é possível que um homem sem Pátria, sem virtudes, sem costumes, arrancado, por meio de um comércio odioso, do seu território, e trazido para o Brasil possa por um simples fato, pela vontade de seu Senhor, adquirir de repente na nossa sociedade direitos tão relevantes $[?]^{91}$

Outros deputados argumentavam que para possuir cidadania, o liberto deveria ter uma ocupação fixa e demonstrar "um bom comportamento". Contudo, um grupo de parlamentares foi a favor da implementação do artigo de maneira bastante ampla, entre eles José da Silva Lisboa, futuro visconde de Cairu. ${ }^{92}$ Para ele, o preceito liberal da

\footnotetext{
${ }^{88}$ DAC, sessão de 23 de setembro, tomo III, p. 90.

${ }^{89}$ DAC, tomo II, p. 689.

${ }^{90}$ DAC, sessão de 30 de setembro, tomo III, p. 132.

${ }^{91}$ SLEMIAN, Seriam todos cidadãos?, p. 844.

92 Visconde de Cairu nasceu na cidade da Bahia em 16 de julho de 1756 e faleceu no Rio de Janeiro em 20 de agosto de 1835. Bacharel em direito canônico e filosófico pela universidade de Coimbra. Participou da Assembleia Constituinte e depois foi senador por sua província natal desde a instituição do Senado, sendo depois conselheiro de Estado. Foi comendador da ordem de Cristo e oficial da do Cruzeiro; membro da sociedade Auxiliadora da indústria nacional do Rio de Janeiro, da sociedade de Agricultura da Bahia e da de Munique, da sociedade filosófica de Filadélfia, da sociedade de Propagação das Ciências industriais de Paris, do Instituto Histórico da França e do Instituto real para a propagação das ciências naturais de Nápoles. Foi fidalgo cavaleiro da casa imperial, grande do império, desembargador do paço. Ficou conhecido por posições políticas conservadoras, mas igualmente por um grande ativismo na
} 
igualdade humana se impunha às discussões de naturalidade, ocupação ou comportamento:

... não me parece de boa razão não dar o Direito de Cidadão a quem adquiriu a Liberdade Civil pelos modos e títulos legítimos estabelecidos no País. Para que se farão distinções arbitrárias dos Libertos, pelo lugar do nascimento, e pelo préstimo e pelo ofício? Uma vez que adquiriram a qualidade de pessoa civil, merecem igual proteção da Lei, e não podem ter obstáculo de arrendar e comprar terras, exercer qualquer indústria (...) O benefício da Lei principalmente recairá sobre os crioulos, sendo estes sempre o maior número dos Libertos. O que na discussão presente se alegou sobre o perigo dos forros vadios, é mero objeto da Polícia e não deve influir em Artigo Constitucional, que supõe regularidade no governo administrativo. Muito se altercou sobre não ter o título de Cidadão Brasileiro quem não tiver propriedade. Se prevalecesse esta regra, até a maior parte dos brancos nascidos no Brasil não seriam Cidadãos Brasileiros, a considerar-se somente a propriedade territorial ou de bens de raiz (...) A propriedade do pobre está nos seus braços e força do corpo, ele prestando as suas obras e serviços pessoais (...) vem a ser membro útil da comunidade (...). ${ }^{93}$

Essa ideia inclusiva da cidadania acabou por vigorar na Assembleia e o inciso foi aprovado tal como propôs Silva Lisboa: "[São cidadãos brasileiros] Os libertos que adquiriram sua liberdade por qualquer título legítimo". ${ }^{94}$

A ideia de integração do negro liberto na sociedade pode ser compreendida a partir de dois pontos: por um lado, pela necessidade de manutenção da ordem social e, por outro, pelo ideário político liberal. Aceitando os ex-escravos na comunidade política, esse dispositivo buscava minorar as tensões sociais existentes entre senhores, escravos e libertos. O medo da elite política de antagonizar os libertos era de que estes se juntassem aos cativos numa sublevação geral que destruísse o arranjo político-social existente. No entanto, esse mesmo concerto político reproduzia a lógica da exclusão, fazendo ressaltar a diferença entre libertos e escravos, colocando aqueles no universo dos homens livres.

Para entender essa exclusão dos libertos de parte importante do campo político é necessário, igualmente, compreender as diferenças no Direito Público dos oitocentos entre os cidadãos ativos e cidadãos passivos. Os cidadãos ativos, nos termos do ideário liberal, eram aqueles que possuíam "vontade livre e autônoma". ${ }^{95}$ Essa condição os

imprensa, por seu vasto conhecimento e capacidade oratória. Para maiores conhecimentos sobre a trajetória de Silva Lisboa ver KIRSCHNER, Tereza Cristina. José da Silva Lisboa, Visconde de Cairu: itinerários de um ilustrado luso-brasileiro. São Paulo: Alameda; Belo Horizonte: PUC-Minas, 2009.

${ }^{93}$ DAC, sessão de 30 de setembro, tomo III, p. 135-136.

${ }^{94} \mathrm{Na}$ Constituição de 1824 ficaria: "[São cidadãos brasileiros] I. Os que no Brasil tiverem nascido, quer sejam ingênuos, ou libertos, ainda que o pai seja estrangeiro, uma vez que este não resida por serviço de sua Nação".

95 SILVA, Cristina Nogueira da. Conceitos oitocentistas de cidadania: liberalismo e igualdade. Análise Social, vol. XLIV (192), 2009, p. 548. 
habilitava para intervir na formação dos poderes públicos, ou seja, de votar e de serem eleitos. Os cidadãos passivos, por sua vez, eram aqueles que não reuniam as condições para serem autônomos e, desta forma, não poderiam participar dos negócios públicos. Preservavam, contudo, seus direitos naturais-civis (liberdade, propriedade e integridade física). ${ }^{96} \mathrm{O}$ critério utilizado no Brasil imperial para aferir esse grau de independência foi o censitário. ${ }^{97}$ Entendia-se que a posse de bens denotava racionalidade e capacidade, enquanto os despossuídos eram entendidos como incapazes. ${ }^{98}$ Outrossim, as posses e riquezas permitiam a atuação e a dedicação exclusiva do representante nos negócios públicos uma vez que este não precisaria se preocupar com sua sobrevivência, sendo, assim, verdadeiramente livre.

Tal divisão, contudo, não era estanque. A ideia dos grupos dirigentes brasileiros ao estabelecerem essa diferença era a de que os cidadãos passivos poderiam se tornar cidadãos ativos caso se esforçassem o suficiente para amealhar a riqueza necessária. Foi esse o argumento de André Rebouças a favor do princípio censitário para a distinção entre cidadãos ativos e passivos. ${ }^{99}$ Assim sendo, a categoria de cidadão passivo correspondia a uma fórmula de suspensão temporária “[d]a participação política ativa de alguns cidadãos"100 e lançava para um futuro indeterminado o momento em que todos poderiam se tornar cidadãos completos.

A esse princípio da propriedade se somava uma noção civilizacional, de que alguns grupos - como os libertos, mas também as mulheres - não estavam ainda preparados para assumir os cargos públicos. No caso particular dos ex-escravos, os motivos seriam a mancha da escravidão e a experiência de ter sido cativo, tendo estado sob o jugo de outrem, que invalidava a participação dos libertos na escolha dos representantes políticos. Essa condição seria resolvida completamente no futuro, com o fim do tráfico, da escravidão e com o passar das gerações.

A cidadania no Império, seus direitos e limites, foi objeto de vários estudos historiográficos nas últimas décadas. ${ }^{101}$ Alguns desses estudos e seus autores apontaram

\footnotetext{
96 Idem.

${ }^{97}$ Até a reforma Saraiva de 1881, poderia ser votante aquele que tivesse renda líquida anual de cem mil reis. Para ser eleitor, 200 mil réis. Para ser candidato a deputado, 400 mil reis. Para senador, o dobro da renda estabelecida para os deputados. Cf. os artigos 45, 92, 94 e 95 da Constituição imperial.

${ }^{98}$ SILVA, Conceitos oitocentistas de cidadania: liberalismo e igualdade, p. 548.

${ }^{99}$ GRINBERG, O fiador dos brasileiros, p. 101-124.

${ }^{100}$ Ibidem, p. 550.

${ }^{101}$ Além de SLEMIAN, Seriam todos cidadãos?, GRINBERG, O fiador dos brasileiros e PEREIRA, O Soberano Congresso, a título de ilustração, podemos citar:

BAJER, Paula. Processo Penal e Cidadania. Rio de Janeiro: Jorge Zahar Editor, 2002.
} 
para a pouca participação política da população nas eleições da época, ressaltaram a ausência de pressão dos setores menos abastados em demandar mais direitos e enfatizaram a exígua presença dos direitos civis apresentados na Carta de 1824 na vida cotidiana. Sublinharam, particularmente, a mão do Estado em demarcar as linhas de cidadania e a maneira "peculiar" ou "fora de lugar" que o liberalismo, cujo pilar fundamental é a garantia do direito civil e da liberdade, foi implantado nos primórdios do Brasil independente. ${ }^{102}$ A pesquisa feita não se alinha com essas interpretações. Antes entende, em consonância com Keila Grinberg, Vantuil Pereira e Andrea Slemian, que o estabelecimento de direitos de cidadania sob a égide da igualdade dos homens livres tal como foi feito abriu o caminho para integração daquelas pessoas no seio da sociedade civil e política brasileira, ainda que essa delimitação forçosamente tornasse o processo lento, haja vista a necessidade primeira de se extinguir a escravidão.

Tal entendimento põe certa ênfase na produção legislativa e nos códigos, ou melhor, no direito, como fundamental para a criação desse corpo civil e político que se estruturava nas primeiras décadas do século XIX. O grupo dirigente do Império utilizou da prática legislativa para consolidar as novas instituições constitucionais e enfrentar as tradições e costumes coloniais ao mesmo tempo em que criavam um ordenamento jurídico especificamente nacional. ${ }^{103}$ A necessidade de se criar novas leis e de forçar seu cumprimento em todo o território do país era uma clara preocupação dos deputados nas primeiras legislaturas. No Parlamento isso se desdobrava numa grande reverência à produção legislativa, como pôde se perceber na primeira citação deste capítulo e noutras discussões sobre forma e regimento, que embora possam soar quase irrelevantes, demonstram o cuidado que os homens daquele período tinham com lei ${ }^{104}$ e a compreensão que possuíam de que somente em sua efetividade poderiam manter o regime constitucional contra seus detratores. Por outro lado, levou os representantes a

CARVAlHO, José Murilo de. Cidadania no Brasil: o longo caminho. Rio de Janeiro: Civilização Brasileira, 2001.

CARVAlHO, José Murilo de; CAMPOS, Adriana Pereira (Orgs.). Perspectivas da cidadania no Império. Rio de Janeiro: Civilização Brasileira: 2001.

MATTOS, Hebe Maria. Escravidão e Cidadania no Brasil monárquico. Rio de Janeiro: Jorge Zahar Editor, 2000.

102 CARVALHO, Cidadania no Brasil: o longo caminho.

CARVALHO, José Murilo de. Cidadania: tipos e percursos. In: Estudos Históricos, vol. 9, no 18, 1996, p. 337-359.

SCHWARZ, Roberto. Ao vencedor as batatas. São Paulo: Duas Cidades, 1977.

${ }^{103}$ Ibidem, p. 199.

${ }^{104}$ Como, por exemplo, disse Vergueiro na Câmara dos Deputados em 1826: "Eu creio que nada há mais decoroso do que satisfazer as leis e práticas nacionais". ACD, quinta sessão preparatória de 3 de maio de 1826, tomo I, p. 18. 
terem especial atenção na reformulação da justiça, da administração - principalmente das províncias -, na criação de novos códigos, como o Código Criminal e o Código de Processo Penal, e na fiscalização, ou ainda, na denúncia de casos de abuso contra os direitos dos cidadãos. ${ }^{105}$

\subsection{A um Estado Constitucional, um Direito Constitucional}

Tendo tratado da formação de um novo país em arrimos constitucionais, faz-se necessário agora apontar algumas questões relativas ao direito durante o período estudado e suas características, ponto importante para se compreender o papel da lei como instrumento de mudança na vida institucional do país e, por corolário, da correlação entre os direitos dos cidadãos e as rotinas de recrutamento e castigo dos soldados, objeto deste trabalho.

Uma das grandes tarefas dos construtores do Império em sua primeira década de existência foi, como já indicado acima, a elaboração de um aparato jurídicoinstitucional coerente com a nova ordem que se pretendia edificar. Fechada a Assembleia Constituinte, essa missão foi retomada pela Assembleia Geral a partir de 1826. Nesse momento, cabia aos legisladores criarem condições para garantir as liberdades públicas e os direitos individuais inscritos na Constituição. Como escreve Lopes: "Era necessário reformar as instituições do Antigo Regime: a justiça, o governo, a fazenda e a guerra. Em todos esses campos, houve alterações."106 Para tanto, o grupo legislativo do Império utilizou-se da própria faculdade de criar leis como fonte do direito e da autoridade estatal e envidou esforços para reorganizar o direito público, antes do direito privado. ${ }^{107}$ Isso se reflete, por exemplo, na reforma das Câmaras municipais de 1828 e nas discussões acerca do Código Criminal de 1830 e do Código de

\footnotetext{
105 SLEMIAN, À nação independente, um novo ordenamento jurídico: a criação dos Códigos Criminal e do Processo Penal na primeira década do Império do Brasil. In: RIBEIRO, Gladys Sabina (Orgs.). Brasileiros e cidadãos. São Paulo: Alameda, 2008, p. 175-206.

$\mathrm{O}$ trabalho de Vantuil Pereira bem demonstra as petições de cidadãos junto à Câmara requisitando que se tomasse providências ao que eles consideravam abusos de autoridades.

${ }^{106}$ LOPES, O Direito na História, p. 258.

${ }^{107}$ Direito público refere-se à relação entre Estado e cidadão ou entre as áreas do constituintes do próprio Estado. Seguindo as considerações de Lopes e Slemian, é dividido em duas áreas: direito administrativo aquele que regula o papel do Estado na administração pública - e o direito constitucional - "entendido como direito fundamental, do qual toda legitimidade legislativa procedia". Cf. LOPES, "Iluminismo e jusnaturalismo no ideário dos juristas da primeira metade do século XIX”, p. 204.

$\mathrm{O}$ direito privado refere-se à regulação entre cidadãos.
} 
Processo Criminal de 1832, ao passo que o Código Civil não entrou em debate e votação durante todo o período de existência da monarquia.

No início do Estado independente, é possível encontrar na noção de direito alguns elementos considerados "modernos", ${ }^{108}$ quais sejam:

(1) o direito é um conjunto de normas, das quais a primeira é a lei, comando ou ordem do soberano e de caráter geral; (2) este conjunto é sistema, um todo integrado e hierarquizado, que se entende completo e coerente de princípios universais; (3) a legislação deve estar acima dos costumes e pode sobrepor-se a eles e revogá-los. ${ }^{109}$

Essas características foram fruto, em grande medida, das modernizações feitas por Pombal, tanto pela consolidação de um sistema de fontes de direito - a Lei da Boa Razão de 1769 - como pela reforma do ensino jurídico de Coimbra. A elite lusobrasileira coimbrã, formada nos quadros desse processo, trouxe essas concepções para o seio do Estado e influenciou sobremaneira o entendimento sobre a lei, qual seja, de que a lei era comando, e comando para ser obedecido à risca. ${ }^{110}$

Tal concepção voluntarista do direito e do papel da legislação coloca o Estado, ou melhor, a vontade soberana de legislar - que no Brasil era dividida entre Imperador e Assembleia ${ }^{111}$-, no centro da função de regular e dirigir a administração - uma visão "instrumentalista" do direito - em contraste com a ideia de que o direito deveria simplesmente se adequar às práticas e costumes da sociedade. ${ }^{112}$ Esse aspecto aparece em várias falas dos parlamentares da primeira legislatura. Como afirmou Lino Coutinho acerca da necessidade de leis regulamentares: "O que precisamos é fazer leis que movam a grande máquina da Constituição. A máquina está montada: falta-lhe o agente de boas leis regulamentares, bem como se precisa dar corda a um relógio". ${ }^{113}$

A metáfora do relógio é interessante porque mostra a necessidade de intervenção humana criando leis para que a máquina, neste caso, a Constituição, funcionasse. Também a imagem é esclarecedora da importância da Carta imperial: as leis dão a corda, mas, digamos, para saber a hora, é necessário sempre olhar para a Constituição. Ou seja, a referência deveria ser o que havia sido demarcado pelos dispositivos

\footnotetext{
${ }^{108}$ Cf. Lopes, esse direito moderno contrapõe-se ao direito comum tardo-medieval. LOPES, Iluminismo e jusnaturalismo no ideário dos juristas da primeira metade do século XIX, p. 198.

${ }^{109}$ Ibidem, p. 198-199.

${ }^{110}$ Ibidem, p. 199.

111 No artigo 11 da Constituição imperial, estabelecia-se que os representantes da Nação eram o Imperador e a Assembleia Geral. No artigo 13, lia-se: "O Poder Legislativo é delegado [pela Nação] à Assembleia Geral com a sanção do Imperador".

112 Ibidem, p. 202. LOPES, O Direito na História, p. 288.

${ }^{113}$ BRASIL. Anais da Câmara dos Deputados (ACD), sessão de 9 de maio de 1826, tomo I, p. 33.
} 
constitucionais. Tal aspecto remete ao significado que a Constituição política do Império possuía para a cultura jurídica da época e para a elite dirigente imperial.

No século XVIII o conceito "constituição" significava "um estatuto, uma regra" ${ }^{\text {114 }}$, aludindo a disposições legais de prática do direito consuetudinário que deveriam ser respeitadas pelo soberano. Progressivamente, ao longo do século XVIII e início do século XIX, no entanto, o conceito foi se tornando menos descritivo e mais normativo, prescritivo. ${ }^{115}$ Como afirma Dieter Grimm:

\begin{abstract}
O termo constituição (...) foi inicialmente um conceito empírico, que passou do âmbito da descrição da natureza ao da linguagem jurídico-política para designar a situação de um país, a forma pela qual este se configurou mediante as características de seu território e seus habitantes, sua evolução histórica e as relações de poder nele existentes, suas normas jurídicas e instituições políticas. No entanto, com o esforço de limitar o poder do Estado em benefício da liberdade dos súditos, que penetrou desde meados do século XVIII na doutrina do direito natural, o conceito de constituição se estreitou progressivamente, eliminando gradualmente os elementos não normativos, até que a constituição apareceu unicamente como a situação determinada pelo direito público. Somente com as revoluções de fins do século XVIII na América do Norte e na França, que aboliram pela força a soberania hereditária e erigiram uma nova sobre a base da planificação racional e a determinação escrita do direito, se consumou a transição de um conceito do ser a um dever-ser. ${ }^{116}$
\end{abstract}

Passando a ser prescritiva, a "constituição" tornava-se "a própria norma jurídica que (...) cria [uma condição jurídica]", ou melhor, estabelecia as "condições jurídicas de validade da própria ordem pública". ${ }^{117}$ Sendo a norma superior, suas diretrizes deveriam ser seguidas por todos, tanto no âmbito público quanto privado - ainda que sua efetividade pudesse ser algo problemático. Nesse sentido, pode-se afirmar em conjunto com José Reinaldo de Lima Lopes que o direito possui um caráter constitutivo da realidade social. ${ }^{118}$

Tornada a Constituição um conjunto superior de regras, todas as demais determinações do Estado deveriam respeitá-la. Outrossim, ela deveria ser um sistema de princípios fechados em si mesmos que se resguardasse de ações arbitrárias do governo. ${ }^{119}$ Para além desse preceito jurídico-normativo, a constituição passou a

\footnotetext{
${ }^{114}$ Apud NEVES, Lúcia Maria Bastos Pereira das; NEVES, Guilherme Pereira das. Constitución Brasil. In: SEBASTIÁN, Javier Fernández. (Org.). Diccionário politico y social del mundo iberoamericano. La era de las revoluciones, 1750-1850. Iberconceptos I. Madrid: Fundación Carolina/Sociedad Estatal de Commemoraciones Culturales / CEPC, 2009, v. 1, p. 339.

${ }^{115}$ FERREIRA, Bernardo. O essencial e o acidental: Bodin (e Hobbes) e a invenção do conceito moderno de constituição. Lua Nova (Impresso), no.88, 2013, p. 392.

${ }^{116}$ Apud FERREIRA, op. cit., p. 392.

${ }^{117}$ Ibidem, p. 400.

${ }^{118}$ LOPES, José Reinaldo de Lima. As palavras e a lei. São Paulo: Editora FGV, 2004, p. 28-32.

${ }^{119}$ SLEMIAN, Sob o Império das leis, p. 27.
} 
significar, no bojo das revoluções do século XVIII, a garantia, por escrito, dos direitos e deveres dos cidadãos. ${ }^{120} E$ a partir desse entendimento que os revolucionários franceses escreveriam em 1789 na Declaração dos Direitos do Homem e do Cidadão: “Toda sociedade na qual a garantia dos direitos não está assegurada nem a separação dos poderes determinada não tem constituição".

No Brasil Império, o conceito de Constituição, além de possuir as características acima descritas, foi articulado ao de Pacto Social. Isso pode ser percebido claramente no debate acerca do projeto de promulgação dos decretos da Constituinte.

Apresentado na sessão de 12 de junho de 1823, no artigo terceiro do projeto, liase: "Os Decretos da presente Assembleia serão promulgados sem preceder sanção". ${ }^{121}$ Entrando em discussão pela primeira vez ${ }^{122}$ no dia 25 de junho, esse artigo gerou intensas altercações entre os deputados.

Entre os mais variados e longos discursos proferidos sobre o tema, destacam-se aqueles feitos por Carneiro de Campos, Henriques de Resende ${ }^{123}$ e Souza França, o primeiro um contumaz crítico do artigo e os outros dois defensores do mesmo.

O deputado Carneiro de Campos, futuro Marquês de Caravelas, construiu sua argumentação a favor da sanção respondendo a quatro perguntas que, para ele, constituíam o busílis da matéria:

De nada menos nos ocupamos do que examinar se negando ao Imperador a sanção nas Leis regulamentares, ou administrativas, que decretarmos nesta Assembleia, nós com efeito o despojamos de um direito essencial, e inseparável do caráter sagrado do Monarca, de que ele se acha revestido? Se procedendo assim nós alteramos a forma do Governo decretado pela Nação? Se abusamos dos poderes que ela nos conferiu? Se finalmente perjuramos? ${ }^{124}$

\footnotetext{
${ }^{120}$ Ibidem, p. 392.

${ }^{121}$ DAC, sessão de 12/06, tomo I, p. 210.

${ }^{122}$ Pelo regimento da Constituinte, depois adotado pela Assembleia Geral, um projeto deveria ser discutido em três momentos antes da aprovação. Primeiramente, discutir-se-ia o mérito da matéria apresentada. Em segundo lugar, artigo por artigo era debatido, e emendas eram apresentadas (modificativas, aditivas ou supressivas). Por fim, na terceira rodada, discutiam-se as emendas e a aprovação final do decreto legislativo a ser promulgado.

${ }^{123}$ Venâncio Henriques de Resende nasceu em 1794 em Sirinhaém, Pernambuco, e faleceu em 1866. Foi presbítero secular, cônego honorário da capela imperial, vigário da freguesia de Santo Antônio do Recife, comendador da ordem de Cristo e oficial da do Cruzeiro. Participou nos levantes de 1817 e de 1824. Colaborou com vários jornais, entre os quais: O Marinbondo, Recife, 1822 e Gazeta Pernambucana, Recife, 1822-1824. Por associação à rebelião de 1817, foi preso, ficando nesta condição até fugir para a Inglaterra em 1821. Participou da Assembleia Constituinte de 1823 e das seguintes legislaturas ordinárias: 1830-1833; 1834-1837 (posse em 3 de maio de 1834); 1838-1841 (posse em 3 de maio de 1838); 18421844 (posse em $1^{\circ}$ de janeiro de 1843); 1849-1852 (posse em $1^{\circ}$ de janeiro de 1850).

${ }^{124}$ DAC, sessão de 25 de junho, tomo I, p. 299.
} 
O cerne de seu raciocínio e ponto de partida de sua arguição era o momento em que havia sido feito o Pacto Social e o que esse havia definido como missão para a Assembleia Constituinte:

\begin{abstract}
... quando para um semelhante fim nos congregamos neste Augusto Recinto já então nós tínhamos ajustado e firmado o nosso Pacto Social, já formávamos uma Nação; só nos restava especificar as condições indispensáveis para fazer aquele Pacto profícuo, estável e firme. Nós fomos encarregados de declarar e determinar estas condições; achamo-nos revestidos do Augusto Poder de organizar o Código Constitucional do Império do Brasil. Porém, por mais amplos que sejam os nossos poderes, eles jamais se poderão reputar tão absolutos e ilimitados, que nos autorizem a mudar, alterar ou transformar o Governo, que a Nação por unânime consentimento tem adotado. (...) pois muito antes de nos eleger para seus Representantes, tinha já decretado que fosse Monárquico Constitucional e Representativo o Governo que a devia reger. Ela já tinha nomeado o Sr. Dom Pedro de Alcântara seu Supremo Chefe, seu Monarca, com o Título de Imperador e seu Defensor Perpétuo. Estas bases jamais podem ser alteradas pela Constituição que fizermos; ou por qualquer Decreto ou Resolução desta Assembleia. ${ }^{125}$
\end{abstract}

Pela exposição acima, parece claro a Carneiro de Campos que o Pacto Social havia sido feito quando da Aclamação do Imperador. Isto posto, à Constituinte cabia apenas regular o que já estava estabelecido, particularmente, definir como seria a divisão dos poderes. Assim sendo, Carneiro de Campos valorizava o papel da Coroa no concerto institucional que se moldava naquele momento, na perspectiva de que ela seria o bastião da ordem social e constitucional contra a anarquia, um contrapeso aos possíveis excessos do Poder Legislativo. ${ }^{126}$

Ora, quais seriam as características marcantes dessa forma de governo escolhida pela Nação no ato de Aclamação? Para o futuro Marquês de Caravelas, o que "verdadeiramente caracteriza o Governo Monárquico Representativo, e o distingue das Repúblicas, é a grande influência que o Monarca tem no Corpo Legislativo". ${ }^{127}$ Essa preponderância se dava com o direito de veto aos atos administrativos ou regulamentares editados pela Assembleia. Considerando isso, para ele então:

\footnotetext{
... é evidente: $1^{\circ}$ Que tirando-se ao Imperador a sanção nas Leis administrativas que decretarmos nesta Assembleia nós o despojamos de um direito essencialmente inerente ao Augusto caráter de Monarca Constitucional, que lhe conferiu a Nação, cujo voto devemos exprimir e não contrariar; $2^{\circ}$ Que certamente contrariamos o voto da Nação que o nomeou seu Monarca Constitucional e quis ser regida por uma Monarquia

125 Idem.

${ }^{126}$ LYNCH, Christian Edward Cyril. A vocação sociológica do legislador: o pensamento político do Marquês de Caravelas. In: RIBEIRO, Gladys Sabina (Org.). Brasileiros e Cidadãos. São Paulo: Alameda, 2008, p. 158.

${ }^{127}$ DAC, sessão de 25 de junho, tomo I, p. 300.
} 
Representativa; porque não tendo ele a sanção, esta Assembleia terá por isso mesmo a preponderância nas Leis que fizer; o Imperador será mero executor delas; e o Governo já não será Monárquico Representativo, será Republicano enquanto se não restituir ao Supremo Chefe da Nação uma regalia inseparável do Monarca. $3^{\circ}$ Que perjuramos; pois solenemente prometemos manter o Governo Monárquico Representativo e o transformamos em uma República, uma vez que passe o Artigo em questão.

Sua longa e bem articulada exposição acirrou os ânimos daqueles deputados que de forma alguma aceitavam a interferência do Imperador nas decisões constituintes e negavam qualquer "direito inerente" ao monarca numa monarquia parlamentar, como Carneiro de Campos afirmava ser o caso do direito de veto. Ainda na mesma sessão de 25 de junho, falou Henriques de Resende. Em seu discurso, o parlamentar pernambucano defendeu o artigo porque, entendia ele, a Nação havia delegado o poder soberano de fazer uma Constituição àquela Assembleia, assim como o poder de determinar, portanto, como haveria de se dar a divisão dos poderes e as atribuições do monarca. Antes de feita a Constituição, que, para ele, era o Pacto Social, o Imperador não poderia se intrometer nas decisões constituintes, nem mesmo nas leis administrativas. Seu argumento, contudo, não é desenvolvido in extremis a ponto de negar a monarquia constitucional, embora fosse o desdobramento lógico. Diz ele:

... os Decretos das Assembleias Constituintes não dependem da Sanção Real: nem é possível que dependam, Sr. Presidente, porque ela é que deve marcar os limites dos Poderes: ela é que deve estabelecer as regras de conduta dos Poderes Constitucionais e a parte que o chefe da Nação deve ter na factura [sic] das Leis; enquanto isto se não faz tudo está em suas mãos; salva a Monarquia Constitucional. Também não posso admitir essa essencialidade da Sanção Imperial: nada é essencial nestas matérias, Sr. Presidente. ${ }^{128}$

Henriques de Resende também não aceitava a tese de Carneiro de Campos de que o Imperador fosse um anteparo aos excessos. Para ele, ao contrário, ele poderia ser um fator desestabilizador do sistema por estar mais sujeito às paixões que os deputados reunidos em Assembleia e daí a necessidade de se estabelecer por escrito as atribuições do imperante antes que ele pudesse exercer seu poder de sanção:

... dizem que a Assembleia não é infalível, e é sujeita às paixões, e o
Imperador, é um Anjo, não tem paixões? O Imperador é mais sujeito a essas
paixões porque tem para elas mais incentivos; comanda a força, dá os
empregos, as honras e é quem executa as Leis e por isso tem mais interesse
em que elas sejam a jeito; nós nada disso temos, e somos temporários, e
tornamos para o que de antes éramos; A Assembleia não é infalível: e o
Imperador é? Nego; É tanto homem como nós; e demais tem maiores
entraves para ver a verdade, mais incentivos de paixões. Sr. Presidente!
Quando os Povos nos mandaram aqui para fazer a Constituição, e as reformas
indispensáveis, estavam convencidos que essa Constituição e que essas

${ }^{128}$ DAC, sessão de 25 de junho, tomo I, p. 302. 
reformas eram necessárias e sabiam quais elas eram. Viemos com plenos poderes; a Constituição e as reformas devem ser efetivas; e de nenhuma forma devem depender da Sanção Imperial os Decretos da Assembleia Constituinte. $^{129}$

O deputado Souza França, tal como Henriques de Resende, partiu também da noção de que a Assembleia estava a construir o Pacto Social e possuía a soberania da Nação para realizar a Constituição e as leis regulamentares necessárias para a reforma do aparato institucional então existente sem a necessidade de sanção imperial. Mas avançou seu argumento e fez algumas diferenças sutis entre a soberania da Assembleia e aquela do Imperador. Segundo ele:

Eu entendo por Soberania o Direito que tem uma Nação qualquer de se constituir e mudar a sua Constituição como e quando lhe convier. É, pois, Soberania um termo próprio da Ciência do Governo que significa faculdade, virtude, poder, enfim, Direito exclusivo que têm os indivíduos de uma Nação coletivamente considerados de estabelecerem a forma de Governo com que convencionam de ser regidos. (...) O Chefe da Nação é, pois, denominado Soberano porque a Nação o colocou no mais alto posto da Hierarquia Política; a Assembleia é Soberana enquanto reunida representa a Nação e exercita um Direito Político exclusivo, que só ela tem, mas não pode por si mesmo exercitar. (...) Quando dizemos que uma Assembleia é Soberana, queremos dizer que exercita o direito da Soberania da Nação, o Direito primitivo da Convenção das Sociedades, o Direito de constituir salvos certos princípios: quando dizemos que o chefe da Nação é Soberano, não significamos nisso a mesma ideia: é outra coisa o que queremos dizer; isto é, que é o superior de todos os indivíduos dessa Nação colocado por eles no mais alto posto da Hierarquia Civil. ${ }^{130}$

Em sua fala fica clara a ênfase que ele coloca no exercício da soberania da Nação pela Assembleia, ao que ele contrapõe a soberania do imperante, chamado de "soberano" somente por ser o primeiro entre os cidadãos, por estar no mais alto posto da sociedade - lugar que alcançou também por delegação da Nação.

Findas as discussões em 29 de julho, o artigo passou como sugerido pela comissão e retirou efetivamente o poder de veto do imperador a qualquer decreto da Assembleia. Essa postura privilegiava, então, a noção de que era a Constituinte que estava construindo o novo Pacto Social ao congregar, no "Augusto Recinto", os "representantes da Nação" para elaborá-lo, em detrimento de uma visão mais centrada na Coroa, qual seja, de que o Pacto havia sido formado na Aclamação do Imperador em outubro de 1822. Esse foi um dos fatores que contribuíram para a deterioração das relações entre a Constituinte e o Imperador, que meses depois a fechou manu militari.

\footnotetext{
${ }^{129}$ DAC, sessão de 25 de junho, tomo I, p. 303.

${ }^{130}$ DAC, sessão de 29 de julho, tomo II, p. 477.
} 
Não obstante, essas duas posições partilhavam de uma opinião comum, a de que a monarquia constitucional e a existência dos direitos individuais não poderiam ser questionadas. Isso porque, tivesse sido o Pacto Social feito pela Aclamação ou pela Assembleia, parecia dado aos deputados que a Nação havia decidido por ter uma monarquia que assegurasse os direitos dos cidadãos do novo Estado. Tal pressuposição transpareceu no anteprojeto de Constituição apresentado à Assembleia no artigo 267 em que se definia o que seria propriamente constitucional na Carta: "É só constitucional o que diz respeito aos limites e atribuições dos Poderes Políticos e aos Direitos Políticos e Individuais". ${ }^{131} \mathrm{O}$ mesmo dispositivo permaneceria na Constituição outorgada no artigo 178. Ou seja, tudo o que se referisse aos poderes Legislativo, Executivo, Judiciário e Moderador e às relações entre Estado e indivíduos eram matérias de emendas constitucionais; todo o resto era matéria ordinária que poderia ser alterada com o trâmite comum de projetos de lei. Isso nos remete, claramente, à noção sumarizada acima de que a Constituição deveria ser um texto escrito, normativo e que preservasse a divisão dos poderes e os direitos individuais dos cidadãos.

Tais noções da lei como comando a ser obedecido e da identificação entre lei e direito, remontam, no mundo luso-brasileiro, a um processo iniciado em meados do século XVIII com a experiência pombalina, como dito anteriormente. No continente europeu esse movimento ganhou grande impulso a partir da codificação realizada na França por Napoleão. Foi essa "nova concepção jurídica"132 que embasou a formação e consolidação de novas entidades políticas. Como afirma Slemian:

... a construção de unidades políticas estáveis que amalgamassem interesses e
territórios tão distintos, como eram tanto os hispânicos como os portugueses,
valeu-se da "lei" como fonte de emanação dos direitos, e também como
instrumento de controle da ordem pública. (...) A criação de uma nova ordem
jurídica nacional e, consequentemente, a negação à herança normativa
colonial, era, portanto, um dos desafios impostos aos americanos. No Brasil,
essa ruptura iniciou-se logo no Primeiro Reinado. À outorga da Carta
Constitucional, seguiu-se a instalação do Parlamento em 1826 que (...) pôs
em prática uma série de reformas na ordenação jurídica que se pretendia para
a nação independente. Isso fez parte de uma atitude consciente e dirigida de
nossos primeiros legisladores que usaram a "faculdade de legislar como fonte
de todo o direito" na consolidação de um ideário de Estado, ou seja, valendo-
se da apropriação do sentido mais moderno então existente para a "lei". ${ }^{33}$

${ }^{131}$ DAC, tomo II, p. 699.

132 SLEMIAN, Sob o Império das Leis, p. 35.

${ }^{133}$ Ibidem, p. 36-37. 
Iniciando sua história como país independente dotado de constituição, de diretrizes para a realização de códigos e de uma concepção legalista de direito, o Império partiria para a reforma de suas instituições ao longo de todo o século XIX.

$$
* * *
$$

Estado, constitucionalismo, soberania, nação, direitos do cidadão. Essas palavras parecem resumir as questões tratadas neste capítulo. Mas o que tudo isso tem a ver com os soldados e o Exército, tema da pesquisa realizada?

Nesse momento de mudanças profundas e aceleradas, também o Exército foi objeto de deliberação sobre a organização que deveria ter nos novos tempos constitucionais. Isso se fazia ainda mais premente pela situação de beligerância interna e externa em que o Império se encontrava - de maneira quase ininterrupta - entre $1822 \mathrm{e}$ 1828. ${ }^{134}$ Tamanhos esforços de guerra levantaram muitas discussões sobre a instituição militar, principalmente quanto às leis relativas ao recrutamento de novos homens, ao emprego de mercenários estrangeiros e aos castigos dispensados aos soldados no descumprimento de seus deveres - particularmente a deserção. Por outro lado, as forças armadas terrestres também inspiravam temores em alguns parlamentares da primeira legislatura que viam nelas instrumentos de opressão e perseguição nas mãos do Imperador, temores fundados no fechamento à ponta de baionetas da Assembleia Constituinte anos antes. Tais preocupações levariam o Exército igualmente ao centro da disputa entre a Câmara dos Deputados e o Poder Executivo para se decidir quem poderia mandar recrutar, quem arbitraria sobre o tamanho das hostes e quem determinaria os homens aptos para o serviço. Essa queda de braço somente seria finalizada em novembro de 1830 com a supremacia do Legislativo, ${ }^{135}$ em detrimento do Imperador e dos ministérios, com a nova lei de organização das forças armadas imperiais.

Assim sendo, no bojo da construção do novo Estado, em plena discussão acerca da soberania, da nação, do papel da lei e do direito, da separação dos poderes, da readequação das antigas instituições às novas bases constitucionais, o Exército também

\footnotetext{
${ }^{134}$ Guerra de independência contra Portugal, ações bélicas contra as Províncias que não haviam aderido imediatamente ao projeto do Rio de Janeiro, guerra contra os insurgentes de Pernambuco em 1824 e, finalmente, contra a República das Províncias Unidas do Rio da Prata entre 1825 e 1828.

${ }^{135}$ MCBETH, Michal Charles. The politicians vs. the generals: the decline of the Brazilian army during the First Empire, 1822-1831. Doctoral Dissertation. University of Washington, 1972.
} 
foi objeto de muitos debates e questionamentos, os quais passaremos em revista nos capítulos seguintes. 


\section{Recrutamento e direitos do cidadão}

Abordar o recrutamento no Brasil do I Reinado não é tarefa fácil. Esse dispositivo militar é trespassado por muitos feixes de questões, mesmo circunscrevendo sua análise aos pontos mais sensíveis aos direitos dos cidadãos do Império, tema desta dissertação. Isso se deve ao fato de que as forças armadas imperiais, tal como várias outras instituições - algumas das quais abordadas no capítulo anterior - estavam sendo repensadas e reorganizadas desde a independência do país.

Algumas tarefas de reordenamento com as quais o governo teve de lidar nesses primeiros anos eram relativamente simples: a distribuição geográfica das tropas, o valor do soldo e das etapas ${ }^{136}$ dos soldados e oficiais, o tamanho do Estado-Maior do Exército. Outras, no entanto, mostravam-se muito mais complexas: estabelecer o número de combatentes, prescrever a contribuição e cota de cada província, definir o sistema geral de recrutamento, determinar quem poderia ser recrutado, quando e como se deveria proceder ao recrutamento, se seria adotada distinção entre voluntários e forçados, qual seria o papel das milícias no conjunto das forças terrestres, se se poderia empregar estrangeiros - africanos e europeus - no serviço militar nacional.

Fatores econômicos e políticos tornavam essas questões complicadas de se resolver. A decisão acerca de quem era recrutável e de qual deveria ser o papel das milícias passava pela escolha estratégica de quais profissões poderiam ceder braços às forças armadas de modo que não se criasse dificuldades econômicas ao Estado. Como se verá, a retirada de homens das lavouras para o serviço das armas seria um grave problema econômico e social ${ }^{137}$ para o Império, um que os deputados não cessariam de denunciar durante os anos de 1826 e 1827.

\footnotetext{
${ }^{136}$ Ração diária entregue aos combatentes de um Exército. No português do século XIX: “etape”.

137 À margem dos problemas econômicos da retirada de homens das lavouras, surgia um problema social: a "desmoralização das famílias" por meio do abandono das mulheres na lavoura. Muitos deputados
} 
Politicamente, os problemas se desdobravam em vários níveis. Num nível abstrato, três questões se colocavam: qual era o lugar de um soldado numa sociedade constitucional? Como conjugar a igualdade civil entre homens livres inaugurada na Constituição com a distinção entre soldados forçados e voluntários? Que forças exatamente compunham o Exército? No plano da economia política e das relações entre Corte e províncias, como deveria se organizar a distribuição do serviço militar? A cota seria igual, já que a todas as províncias cabia acorrer com homens à defesa da pátria, ou proporcional ao tamanho e às capacidades de cada uma? Ter-se-ia, ainda, discussões mais concretas de fundo regional e nacional: milícias de uma província poderiam servir em outra? Quando seria legítimo esse tipo de transferência de forças? De outro lado, as forças brasileiras necessitariam de forças estrangeiras? Por que aceitar alemães e irlandeses como soldados no Brasil? $\mathrm{E}$ os africanos alforriados, poderiam eles ser soldados?

Essas problemáticas, para além de discussões técnico-militares, foram entremeadas de interesses regionais e, mais importante ainda, entraram no bojo das disputas e conflitos entre a Câmara dos Deputados e o Executivo - conflitos que se apresentam inicialmente entre os deputados e os ministros e, nos anos finais da década de 1820, entre os parlamentares e o Imperador. A análise dos debates naquela casa permitiu entrever diversas tensões no Estado que se formava e seus reflexos nas perspectivas e preocupações daqueles que estavam no Executivo e no Legislativo acerca do papel do soldado e seus direitos.

Este capítulo é uma exposição das principais discussões sobre as relações entre o recrutamento $\mathrm{e}$ os direitos dos cidadãos inaugurados com $\mathrm{o}$ movimento constitucionalista e coroados com a Carta de 1824. Para facilitar a narrativa, este texto divide-se em três partes: uma breve introdução do estado geral do Exército no princípio do Primeiro Reinado - o número de combatentes, sua estrutura, organização geral, sua distribuição geográfica -, uma análise das Instruções para o recrutamento e uma exposição de dois casos de maus-tratos de recrutas em Minas Gerais e no Ceará.

levantaram tal problema, afirmando que um miliciano, ao deixar suas esposas e filhas para servir por longos períodos, retornava à sua casa somente para encontrar suas mulheres "reduzidas à ultima miséria e até mendicidade: vi filhas prostituídas e enfim muitos outros casos". Cf. ACD, sessão de 14 de junho de 1826, tomo II, p. 135-136, discurso do deputado Cunha Mattos. 


\subsection{Uma breve introdução ao Exército do Primeiro Reinado}

\subsubsection{A organização geral das forças imperiais}

A organização das forças armadas do Império do Brasil foi herdada do período colonial. A última sistematização das hostes luso-brasileiras foi realizada pelos códigos militares redigidos pelo Conde de Schaumbourg-Lippe na última metade do século XVIII $^{138}$ e a partir do reordenamento feito por d. João VI durante seu governo no Rio de Janeiro.

Numa análise do ponto de vista formal, o Exército era dividido, até a reforma de 1830, em força de primeira linha - ou Exército regular -, milícias e ordenanças. Os soldados da primeira linha recebiam soldo e a eles cabia guardar as fronteiras e lutar contra os inimigos internos e externos, em outras palavras, fazer a guerra. As milícias eram corpos auxiliares não pagos encarregados de manter a ordem nas províncias e somente deveriam participar de lutas contra forças estrangeiras em casos de invasão da província natal. ${ }^{139}$ Por fim, as ordenanças eram corpos locais, que abrangiam todos os homens livres de 18 a 60 anos, que não estavam alistados na força de primeira linha ou nas milícias, e deveriam manter a paz e tranquilidade nas localidades. ${ }^{140}$ As milícias e as ordenanças foram extintas com a lei de 18 de agosto de 1831.

O emprego das forças armadas era de competência privativa do poder Executivo $^{141}$ e somente poderia se reunir por expressa ordem de "autoridade legítima". ${ }^{142}$ Como chefe do poder Executivo, o Imperador tornava-se, por consequência, o comandante em chefe das forças armadas. ${ }^{143}$ Cabia, contudo, à Assembleia Geral - Senado e Câmara reunidos - fixar anualmente as forças ordinárias e extraordinárias de terra e mar. ${ }^{144}$ Caso o Parlamento não designasse a força militar permanente, o governo poderia manter a força presente. ${ }^{145}$ A realização do

\footnotetext{
${ }^{138}$ Cf. RODRIGUES, Neuma Brilhante. Nos caminhos do Império: a trajetória de Raimundo José da Cunha Mattos. Tese de Doutorado: Universidade de Brasília, 2008.

${ }^{139}$ MCBETH, Michal Charles. The politicians vs. the generals: the decline of the Brazilian army during the First Empire, 1822-1831. Doctoral Dissertation. University of Washington, 1972, p. 8.

${ }^{140}$ WEHILING, Arno; WEHLING, Maria José. Exército, milícias e ordenanças na Corte Joanina: permanências e modificações. Da Cultura. Ano VIII, n. 14, jun. 2008, p. 26-32. Disponível em: <http://www.funceb.org.br/images/revista/5_2q0t.pdf>. Acesso em: 15/01/2015, às 10:00.

${ }^{141}$ Cf. Art. 148 da Constituição do Império.

${ }^{142}$ Cf. Art. 147.

${ }^{143}$ Cf. Art. 102.

${ }^{144}$ Cf. Art. 15 , inciso XI.

${ }^{145}$ Cf. Art. 146.
} 
recrutamento, no entanto, era de iniciativa privativa da Câmara dos Deputados, ou seja, o Executivo deveria pedir à Câmara a autorização para recrutar. ${ }^{146}$

Essa engenharia política, embora desse ao Executivo força considerável, contrabalançava-a ao colocar nas mãos do Legislativo a determinação do número total de homens a servir e a prerrogativa do recrutamento. Tal divisão de atribuições criava um equilíbrio entre os poderes característico dos regimes liberais europeus do período. Conforme afirmaria anos depois o Marquês de São Vicente em suas análises da Constituição imperial:

O Estado demanda, pois, a existência e conservação de forças permanentes
de mar e terra; mas quem deverá fixá-las? Para levantá-las e mantê-las é
indispensável exigir do povo um certo número de homens, ou por outra, uma
contribuição de sangue e liberdade; é portanto necessário ouvi-lo e obter seu
consentimento por meio de seus representantes; é uma atribuição legislativa.
Acresce ainda que a maior ou menor quantidade de forças importa maior ou
menor despesa ou sacrifício dos contribuintes, maior ou menor desfalque na
produção. Uma força excessiva pode mesmo ser perigosa, ameaçar as
instituições e as liberdades públicas. Consequentemente a lei e só a lei é
quem deve determinar, fixar a quantidade das forças, tanto de mar quanto de
terra. (...) nos governos constitucionais nenhum poder tem o direito de
levantar força alguma senão em virtude da lei e nos precisos termos dela; se
os ministros tivessem essa atribuição poderiam onerar o Estado e comprimir
suas liberdades. A fixação das forças deve ser, pois, proporcionada às
necessidades; e como estas são móveis, ou variáveis, por isso mesmo ela
deve ser ânua, e nunca determinada senão depois da precisa informação do
governo. É este quem está mais habilitado para calcular, ou antes reconhecer
a quantidade necessária; é ele quem responde pela segurança interior e
exterior do Estado; deve pois apresentar a respectiva proposta. ${ }^{147}$

Não obstante, essa organização e divisão das atribuições levariam a uma série de tensões durante o Primeiro Reinado entre os interesses do Executivo e os do Legislativo. O primeiro preocupava-se em manter uma grande força militar para demonstrar força aos vizinhos e trazer paz interna ao Império, enquanto que o segundo enfatizava a busca pelo equilíbrio fiscal e afirmava confiar nas milícias como forças de manutenção da ordem.

Os números de combatentes nesse início do reinado de Pedro I são inexatos. Os chamados "mapas" das forças militares - que deveriam ser realizados pelos comandantes e governadores das armas das províncias - eram considerados incompletos e malfeitos pelos deputados e ministros, sendo que algumas províncias sequer enviavam os documentos demandados pelo governo. Somente temos, assim, uma vaga noção de quantos soldados e oficiais serviam na primeira linha e nas milícias. De acordo com

\footnotetext{
${ }^{146}$ Cf. Art. 36, inciso II.

${ }^{147}$ BUENO, José Antônio Pimenta. Direito Público brasileiro e análise da constituição do Império. Brasília: Senado Federal, 1978, p. 93-94.
} 
Oscar Wiederspahn, em 1826, a primeira linha do Exército brasileiro contava, aproximadamente, com 29 batalhões de caçadores, 7 regimentos de cavalaria, 12 corpos de artilharia de posição, 5 de artilharia montada e 3 batalhões de granadeiros que perfaziam um total de 26.225 homens, entre oficiais e soldados. As milícias, por sua vez, eram compostas de 89 batalhões de caçadores, 38 regimentos de cavalaria, 4 brigadas montadas de guarda-costas e 8 baterias isoladas, num total de 117.241 combatentes. ${ }^{148}$ Essa informação, no entanto, não era de conhecimento dos dirigentes naquele período. Em 1827, o deputado Cunha Mattos afirmava que os deputados da Comissão de Guerra, da qual era membro, ignorava até então "o exato número das nossas tropas; o mesmo ministro da guerra o ignora[va]". 149

Informações mais acuradas seriam expostas em 1829, em longo relatório do então ministro da guerra Joaquim de Oliveira Álvares. ${ }^{150}$ De acordo com esse documento, caso todos os corpos estivessem completos, o número total de homens de $1^{\text {a }}$ linha seria de 33.276. No entanto, em 1828, o total de homens era de 25.742 e, em 1829 , a cifra havia baixado para 22.909. O governo, por seu ministro, pediu aos deputados que mantivessem ao menos 20.200 homens para os anos de $1830-1831$. $^{151}$

Entre 1822 e 1831, a distribuição geográfica das tropas de primeira linha variou bastante. De modo geral, no entanto, pode-se afirmar que os soldados se concentravam, principalmente, na Corte, na Bahia e no Rio Grande de S. Pedro do Sul. ${ }^{152}$ No período da guerra contra as Províncias Unidas, particularmente em 1827, as tropas presentes na Cisplatina e no Rio Grande somariam mais de 10.000 homens.

Hierarquicamente, a primeira linha do Exército se estruturava em 1831 conforme o quadro a seguir: ${ }^{153}$

\footnotetext{
${ }^{148}$ WIEDERSPAHN, H. Oscar. Campanha de Ituzaingó. Rio de Janeiro: Biblioteca do Exército Editora, 1961 , p. 56.

${ }^{149}$ ACD, sessão de 8 de agosto de 1827, tomo IV, p. 81.

${ }^{150}$ Filho de Joaquim de Oliveira Alvares, nascido na ilha da Madeira, em Portugal, em 19 de novembro de 1776, faleceu em Paris, no ano de 1835. Era bacharel em matemática e filosofia pela universidade de Coimbra. Foi tenente-general do Exército; membro do conselho do Imperador D. Pedro I; da Grã-Cruz da ordem da Rosa; foi comendador da ordem de Avis e oficial da do Cruzeiro. Foi ministro da guerra do gabinete de 16 de janeiro de 1822 e depois novamente entre 1828 e 1829. Foi eleito deputado para a segunda legislatura representando a província do Rio Grande do Sul.

${ }^{151}$ BRASIL. Relatório do Ministério da Guerra. Transcrito nos Anais da Câmara dos Deputados, sessão de 10 de junho de 1829 , p. 61. Em 1829, contudo, a lei de fixação das tropas não foi promulgada devido à demora em seu trâmite.

${ }_{152}$ BRASIL. Coleção de Leis do Império. 1824, vol. 1 parte II, p. 88-95.

${ }^{153}$ Cf. SOUZA, Adriana Barreto de. O exército na consolidação do Império: um estudo histórico sobre a política militar conservadora. Rio de Janeiro: Arquivo Nacional, 1999, p. 52.
} 
Tabela 1 - Hierarquia do Exército ${ }^{154}$

\begin{tabular}{|c|c|}
\hline \multirow{2}{*}{ Oficiais } \\
\hline \multirow{2}{*}{ Oficiais-Generais } & Marechal do Exército \\
& Tenente-general \\
& Marechal de Campo \\
& Brigadeiro \\
\hline Oficiais superiores & Coronel \\
& Tenente-coronel \\
& Major \\
\hline Oficiais subalternos & Capitão \\
& Primeiro-tenente \\
& Segundo-tenente \\
\hline Oficiais inferiores & Primeiro-sargento \\
& Segundo-sargento \\
& Forriel \\
\hline
\end{tabular}

\begin{tabular}{|c|}
\hline Baionetas \\
\hline Cabos \\
Anspeçadas \\
Soldados \\
\hline
\end{tabular}

As gratificações recebidas pelos combatentes do Exército foram modificadas com alguma frequência durante esse período. De modo geral, eram de dois tipos. Os oficiais recebiam o soldo mensalmente e gratificações por comando ou atuação no Estado-Maior, e o grupo dos "baionetas" ganhava a paga baseada no dia de serviço e recebiam a cada 5 dias. Esperava-se que os oficiais pagassem por seu próprio sustento habitação, roupa, comida -, enquanto ao Estado caberia prover os soldados. ${ }^{155}$

${ }^{154}$ Cf. SOUZA, Adriana Barreto de. O exército na consolidação do Império: um estudo histórico sobre a política militar conservadora. Rio de Janeiro: Arquivo Nacional, p. 52.

${ }^{155}$ MCBETH, The politicians vs. the generals: the decline of the Brazilian army during the First Empire, 1822-1831, p. 17. 
Tabela 2 - Soldos a partir do Decreto de 29 de Abril de 1823

\begin{tabular}{lc}
\hline \multicolumn{1}{c}{ Oficiais } & Soldo por mês \\
\hline Tenente-General empregado & $120 \$ 000$ \\
Tenente-General não-empregado & $100 \$ 000$ \\
Marechal de Campo & $75 \$ 000$ \\
Brigadeiro & $60 \$ 000$ \\
Coronel & $54 \$ 000$ \\
Tenente-Coronel & $48 \$ 000$ \\
Major & $45 \$ 000$ \\
Tenente no cargo de Ajudante & $20 \$ 000$ \\
Alferes no cargo de Ajudante & $17 \$ 000$ \\
Tenente no cargo de Quartel-Mestre & $18 \$ 000$ \\
Alferes no cargo de Quartel-Mestre & $17 \$ 000$ \\
Tenente no cargo de Secretário & $18 \$ 000$ \\
Alferes no cargo de Secretário & $15 \$ 000$ \\
Capelão & $15 \$ 000$ \\
Cirurgião-mor & $18 \$ 000$ \\
Ajudante de cirurgia & $15 \$ 000$ \\
Capitão & $24 \$ 000$ \\
Tenente & $18 \$ 000$ \\
\hline
\end{tabular}

Tabela 3 - Soldos a partir do Decreto de 29 de Abril de 1823

\begin{tabular}{lcc}
\hline \multicolumn{1}{c}{ Posto } & Gratificação de comando & Gratificação por servir no Estado-Maior \\
\hline Coronel & $30 \$ 000$ & $40 \$ 000$ \\
Tenente-Coronel & $25 \$ 000$ & $35 \$ 000$ \\
Major & $25 \$ 000$ & $15 \$ 000$ \\
Capitão & $10 \$ 000$ & $15 \$ 000$
\end{tabular}


Tenente

$5 \$ 000$

$10 \$ 000$

Alferes

$5 \$ 000$

$10 \$ 000$

Tabela 4 - Soldos a partir do Decreto de 29 de Abril de 1823

\begin{tabular}{lc}
\hline \multicolumn{1}{c}{ Posto } & Soldo por dia \\
\hline Sargento Ajudante & $\$ 300$ \\
Sargento Quartel-Mestre & $\$ 240$ \\
Alveitar & $\$ 300$ \\
Tambor-mor & $\$ 120$ \\
Corneta-mor de Cavalaria & $\$ 240$ \\
Cabo de Tambores & $\$ 100$ \\
Pífano & $\$ 080$ \\
Mestre de Música & $\$ 900$ \\
$1^{\circ}$ Músico & $\$ 350$ \\
$2^{\mathbf{o}}$ Músico & $\$ 200$ \\
Aprendizes de $1^{\text {a }}$ Classe & $\$ 160$ \\
Aprendizes de $2^{\text {a }}$ Classe & $\$ 100$ \\
\hline
\end{tabular}

Tabela 5 - Soldos a partir do Decreto de 29 de Abril de 1823

\begin{tabular}{l|c|c|c}
\hline \multirow{2}{*}{\multicolumn{1}{c|}{ Posto }} & \multicolumn{3}{|c}{ Soldo } \\
\cline { 2 - 4 } & Infantaria e Caçadores & Cavalaria & Artilharia \\
\hline $1^{\circ}$ Sargento & $\$ 160$ & $\$ 210$ & $\$ 200$ \\
$2^{\circ}$ Sargento & $\$ 120$ & $\$ 190$ & $\$ 180$ \\
Forrieis & $\$ 100$ & $\$ 130$ & $\$ 120$ \\
Cabos & $\$ 090$ & $\$ 110$ & $\$ 100$ \\
Anspeçadas & $\$ 085$ & $\$ 095$ & $\$ 095$ \\
Tambor ou Corneta & $\$ 110$ & $\$ 170$ & $\$ 110$ \\
Ferrador & $\$ 110$ & $\$ 110$ & $\$ 110$ \\
Soldados & $\$ 080$ & $\$ 090$ & $\$ 090$ \\
\hline
\end{tabular}

Tabela 6 - Soldos a partir do Decreto de 29 de Abril de 1823

\begin{tabular}{lcc}
\hline \multicolumn{1}{c}{ Posto } & Artilheiros condutores & Artilheiros engenheiros \\
\hline $1^{\circ}$ Sargento & $\$ 180$ & $\$ 240$ \\
$2^{\circ}$ Sargento & $\$ 120$ & $\$ 210$ \\
Forrieis & $\$ 120$ & $\$ 200$ \\
Cabos & $\$ 100$ & $\$ 180$ \\
Anspeçadas & $\$ 095$ & $\$ 150$ \\
Tambor ou Corneta & $\$ 120$ & $\$ 110$ \\
Ferrador & $\$ 160$ & $\$ 110$ \\
Soldados & $\$ 090$ & $\$ 140$ \\
\hline
\end{tabular}


Para se compreender o poder de compra dos salários dos soldados é interessante comparar com preços de bens de consumo básico. Charles McBeth traz em seu livro três exemplos de 1829: uma dose de rum, um pacote de 200 cigarros e uma libra de sal variavam entre $\$ 160$ a $\$ 240$, o que para um soldado era um valor considerável. ${ }^{156}$ Devese levar em conta ainda que houve uma grande depreciação da moeda nacional, o que corroeu o já diminuto poder de compra. ${ }^{157}$ Além disso, eram frequentes os atrasos no pagamento, o que forçava muitos soldados a buscarem outras ocupações para sobreviver. $\mathrm{O}$ atraso e os baixos soldos seriam objetos de duras críticas no Parlamento. ${ }^{158}$

\subsubsection{O Exército como problema}

Para se compreender melhor a complexa organização das forças armadas desse período, é importante ter em mente que a composição e o papel delas eram objeto de disputas e discussão na década de 1820.

Na sessão de 8 de agosto de 1827, o deputado Holanda Cavalcante ${ }^{159}$ iniciou o debate na Câmara argumentando contra um projeto que previa o número de 30.000 soldados para o ano de $1828 .{ }^{160}$ Afirmou ele:

(...) é preciso fixar qual é a força de terra, quem é que compõe esta força antes de fixar o número de indivíduos que a compõem, convém atender que o ministro no seu ofício fala da tropa de $1^{\text {a }}$ linha, e nela inclui a polícia, os recrutas e os veteranos; (...) deve haver muita dúvida se a polícia pode ser

\footnotetext{
${ }^{156}$ Ibidem, p. 18.

${ }^{157}$ BUESCU, Mircea. 300 anos de inflação. Rio de Janeiro: Apec, 1973.

CAVALCANTI, Amaro. O meio circulante nacional. Brasília: Editora Universidade de Brasília, 1983. CARREIRA, Liberato de Castro. História financeira e Orçamentária do Império do Brasil, 2 tomos. Brasília: Senado Federal, 1980.

${ }^{158}$ Em maio de 1829, o deputado Feijó denunciou a falta de pagamento dos soldados do Exército do Sul e pediu esclarecimentos. O ministro da guerra respondeu no mês seguinte afirmando dever 10 meses de soldos aos combatentes. Lino Coutinho discordou, sustentando que alguns soldados estavam sem receber há 18 ou 19 meses. ACD, sessão de 25 de maio de 1829, tomo II, p. 138. Idem, tomo III, p. 85.

159 Antônio Francisco de Paula Holanda Cavalcante de Albuquerque nasceu em Pernambuco em 21 de agosto de 1797 e faleceu no Rio de Janeiro em 14 de abril de 1863. Assentou praça no Exército aos dez anos de idade, sendo promovido a tenente-coronel, em que se reformou em novembro de 1832 . Serviu em Moçambique, como ajudante de ordens do governador, e em Macau, sendo nomeado lente da escola real de pilotos e sargento-mor do batalhão do príncipe regente. Foi eleito deputado por sua província em diversas legislaturas e para o Senado em 1838. Foi ministro da fazenda no gabinete de 4 de outubro de 1830 e no de 18 de março de 1831 . Foi ministro do império e interinamente da fazenda no gabinete de 3 de agosto de 1832 e ministro da marinha no gabinete de 24 de julho de 1840. Era conselheiro de Estado, gentil-homem da imperial câmara e Visconde de Albuquerque.

${ }^{160} \mathrm{O}$ projeto não passou pelo trâmite do Senado a tempo de ser implementado. O primeiro projeto de fixação de forças a ser votado e executado foi o de 24 de novembro de 1830.
} 
considerada como parte do Exército; e assim também os recrutas e os veteranos, e ainda há ponto muito dificultoso para se resolver, que vem a ser se os milicianos consideram-se força de terra (...). Querer que a tropa de $2^{\mathrm{a}}$ linha [milícias] seja força de terra é querer fazer do Brasil uma colônia russa (...). Se estes cidadãos [milicianos] forem considerados como compondo a força armada, o executivo pode empregá-los como bem lhe convier (...): dirá o ministro aos milicianos, vós sois militares, ide portanto para aqui ou para ali. (...) a tropa de $2^{a}$ linha não é força armada; aliás o Brasil não é império constitucional, é uma colônia militar russa, e antes quero que o Exército fique incompleto do que tenha o governo a arbitrariedade de tocar nas milícias. ${ }^{161}$

Percebe-se aqui a complexidade e amplitude do debate acerca das forças armadas no Primeiro Reinado. O questionamento de Cavalcante é interessante porque indica a existência de disputas e debates sobre a instituição. O que estava em jogo era o poder do Executivo não só de mobilizar um grande número de tropas, mas de influenciar diretamente a vida dos milicianos, já que se as milícias fossem consideradas parte do Exército - entendido aqui como sinônimo das forças de $1^{\mathrm{a}}$ linha - o ministro da guerra poderia movimentá-las a seu arbítrio, retirando os indivíduos de suas províncias e de suas atividades econômicas. Esta última questão foi abordada em vários momentos durante a primeira legislatura, de que se traz o exemplo do deputado Batista Pereira: "Como é Sr. Presidente, que havemos de ver florescente a agricultura, de que tanto necessitamos, se os pobres lavradores quase todos milicianos não são protegidos por uma lei salutar?". 162

No discurso de Holanda Cavalcante também se vê claramente que havia uma desavença entre um modelo de exército que integrava as milícias às campanhas militares de $1^{a}$ linha e outro que propõe desvincular aquelas destas últimas. Embora, na prática, o governo tenha se utilizado de milícias na guerra contra as Províncias Unidas (1825-1828), fazendo delas forças militares de facto, não se pode negligenciar os modelos distintos que estavam sendo apresentados e que embasariam as discussões posteriores acerca da Guarda Nacional. Além disso, nessa fala Cavalcante também expõe rapidamente a relação entre tamanho da tropa e tipo de governo, ao dizer que o Brasil não seria um império constitucional, mas uma colônia militar russa, caso prevalecesse a concepção de que os milicianos seriam militares. Essa conexão, que apresenta uma determinada perspectiva acerca do governo e de seu aparato militar, voltaria a ser tema de discussão em 1830.

\footnotetext{
${ }^{161}$ ACD, sessões de 7 e 9 de agosto de 1827 , tomo IV, p. 79 e 86.

162 ACD, sessão de 18 de maio de 1826, tomo I, p. 79.
} 
Na sessão de 28 de julho de 1830, o deputado Ernesto Ferreira França, ao defender a redução radical no contingente de homens do Exército - de pouco mais de 20.000 para 6.000 - afirmou:

\begin{abstract}
A força dos governos representativos consiste na preponderância dos interesses que esses governos defendem; e quais são esses interesses? São os interesses de todos os cidadãos, são os interesses do povo contra os interesses individuais de um ou de outro. Por consequência a força de um governo representativo, qual o governo brasileiro, deve consistir de todos os cidadãos que gozam de direitos políticos; a organização desta força deve ser feita sobre um projeto de guardas nacionais; esta é a verdadeira força (...). ${ }^{163}$
\end{abstract}

Pouco depois, Lino Coutinho foi além e peremptoriamente asseverou:

Sr. Presidente, um país constitucional não precisa de muita tropa; isto é bom
para esses países onde o homem se acha abatido pela escravidão, nestes o
grande número de tropa é necessário. Quando um viajante vir em qualquer
parte do mundo um país carregado de tropa, pode dizer sem mais outra
investigação - este país é escravo - pelo contrário, quando vir um país aonde
há pouca tropa em relação à sua população pode dizer - este país é livre; isto
é um axioma, senhores, a liberdade não se coaduna com grande número de
tropa. ${ }^{164}$

Percebe-se nos dois discursos o temor que esses e outros deputados tinham da existência de um exército grande. Por um lado, preocupavam-se que uma força tal fosse utilizada pelo governo para atacar as liberdades civis e políticas dos cidadãos do Império. Esse medo era alimentado pelas experiências recentes no Império, como o fechamento da Assembleia Legislativa de 1823 e a instalação da comissão militar em Pernambuco depois da Confederação do Equador em 1824. Por outro lado, a existência de uma estrutura militar enraizada em vários grupos da sociedade traria outro problema político, qual seja, a questão da obediência cega ao governo, do qual se tratará em maior profundidade adiante. A questão que se colocava era: se a hierarquia militar é baseada na disciplina e obediência, os cidadãos que estivessem nas forças armadas não poderiam contrapor-se às ordens do governo sem cometer um crime, o que lhes tiraria, na prática, o direito de resistência.

Para esses parlamentares um governo constitucional deveria se basear na força de milícias compostas por cidadãos ativos e não num exército permanente e regular. Essa ideia de organizar os cidadãos em corpos paramilitares ganhou mais força na medida em que o Exército de primeira linha foi visto como formado por elementos

\footnotetext{
${ }^{163}$ ACD, sessão de 28 de julho de 1830, tomo II, p. 245.

${ }^{164}$ Ibidem, p. 249.
} 
"perigosos" da sociedade - a quem os deputados chamavam de "vadios"165 -, não se mostrou capaz de combater rebeliões internas ${ }^{166} \mathrm{e}$, ainda pior para a elite reunida no Parlamento, participou de alguns movimentos de dissensão nas províncias.

Para além de discussões teóricas, o debate era informado pela experiência das guerras de independência dos Estados Unidos e do Brasil - particularmente o teatro de guerra baiano - em que as milícias tiveram um papel preponderante em levar os movimentos independentistas à vitória. Pode-se dizer, assim, que, num nível abstrato, para esses deputados, defender uma força militar diminuta e contar com as milícias para manter a ordem - tal como se concretizou com a criação da Guarda Nacional - era um meio de se resguardar os direitos civis e políticos dos cidadãos do Império ao diminuir o aparato coercitivo do governo.

Tal posição contrastava absolutamente com as intenções dos ministérios de Pedro I. Para eles, a manutenção de um Exército grande justificava-se por três razões: para a manutenção da paz interna, para a proteção externa e pela dificuldade em se recrutar homens rapidamente para preencher as fileiras em caso de guerra. Conforme afirmou o ministro da Guerra em seu relatório de 1830:

O governo de sua S.M. Imperial (...) não duvida que a assembleia geral legislativa tomará em consideração os justos e poderosos motivos que o obrigaram a solicitar a decretação da força proposta [18.416 homens]; cujo cálculo precedido da mais séria e circunspecta meditação foi baseado sobre as razões seguintes: O Império do Brasil, que além de atender à sua segurança e tranquilidade interna, tem de sustentar a dignidade que lhe compete entre as nações, apresenta, senhores, como ninguém ignora, de um lado a sua vasta fronteira marítima, cujos variados e importantes portos necessita conservar regularmente guarnecidos; e de outro lado oferece o desenvolvimento de uma linha marcada sobre um território não só limítrofe de muitos estados americanos, que ainda infelizmente existem pela maior parte envolvidos em comoções políticas; mas também de possessões que conservam neste continente três poderosas nações europeias. (...) Em primeiro lugar, dita a prudência e política a conservação de pontos militares, donde com prontidão se possa, ou prestar socorros no caso de agressão estrangeira ou prevenir e sufocar desunião interna (...). (...) é fácil conhecer a impossibilidade que existe entre nós de recrutar o exército com celeridade e

\footnotetext{
${ }^{165}$ Conforme criticou o deputado Cunha Mattos: "Não há privilegio senão para afilhados do vigário, o filho do oficial de ordenanças, o homem rico, destes eu nunca vi entre inumeráveis, que eram trazidos para esta corte: só vem os filhos de lavrador, que não tem proteções, este é que se diz que são vadios! Pois se são vadios, vão para o exército; se são ladrões vão para o exercito, se são facinorosos, vão para o exercito! O soldado, que deve defender a pátria, há de ser tirado dessa classe, e aqueles que deverão ser alistados, não vem cá porque tem protetores!". ACD, sessão de 26 de maio de 1826, tomo I, p. 136.

166 Particularmente a revolta dos soldados mercenários de junho de 1828 em que o governo alistou cidadãos para combater os revoltosos e necessitou do auxílio de ingleses e franceses para debelar o movimento.
} 
preenchê-lo de um igual número de praças disciplinadas se imperiosas circunstâncias o exigirem. ${ }^{167}$

Esse embate de projetos políticos tornou-se tanto maior e mais grave quanto as finanças do Império se deterioravam. Em 1828 e 1829, conforme os dados apresentados pelo ministro da fazenda, os ministérios da Guerra e da Marinha juntos somavam respectivamente $43,77 \%$ e $46,66 \%$ do orçamento total, ao mesmo tempo em que o Império apresentava um déficit de 7.387:953\$118 e 4.984:807\$281 relativos aos mesmos anos. ${ }^{168}$ Nas discussões para a fixação da força terrestre de 1830 , percebe-se também grande preocupação do Parlamento em diminuir o tamanho das hostes de modo a economizar dinheiro o suficiente para pagar os empréstimos externos e investir em outras áreas, o que se conjugava harmoniosamente com as ideias políticas apresentadas.

Essa disputa em torno do significado do Exército e do serviço das armas apresentou-se novamente na discussão acerca da lei de responsabilidade dos empregados públicos. Em 29 de maio de 1826, o deputado Vasconcelos apresentou um extenso projeto de lei sobre o tema. Dividido em três títulos e dispondo dos vários crimes e erros que os funcionários poderiam cometer, ${ }^{169}$ representou um grande esforço em enquadrar os empregados nos marcos legais da Constituição. Seu primeiro artigo, e o que mais interessa a esta pesquisa, foi colocado em discussão nas sessões de 4 e 5 de julho do mesmo ano, não muito tempo depois de graves acusações contra o comandante das armas de Minas Gerais por maus tratos aos milicianos mineiros de que se tratará adiante. Nesse artigo, lia-se que:

Art. 1. São responsáveis os empregados públicos: 1. Que derem qualquer ordem vocal ou por escrito, seja qual for a sua denominação. 2. Aquele por cujos votos for tomada qualquer deliberação. 3. Os que não fizerem efetivamente responsáveis os seus subalternos, sendo-lhes requeridos, ou

\footnotetext{
167 BRASIL. Relatório do Ministério da Guerra. Transcrito nos Anais da Câmara dos Deputados, sessão de 19 de junho de 1830, p. 444.

${ }^{168}$ Apud PEREIRA, Ao Soberano Congresso (tese), p. 120-122.

${ }^{169}$ Os títulos eram: I. Da responsabilidade dos empregados públicos em geral; II. Dos crimes e erros dos empregados públicos; III. Do processo de responsabilidade. O título II era dividido em XIX capítulos, compreendendo os seguintes crimes: I. Dos crimes contra a forma do governo em geral; II. Dos crimes contra o Imperador; III. Dos crimes contra o poder legislativo; IV; dos crimes contra o poder judiciário; V. Dos crimes relativos à segurança do Estado; VI. Dos empregados públicos que revelam os segredos de ofício ou abrem cartas; VII. Das prevaricações dos empregados públicos; VIII. Das peitas; IX. Do peculato; X. Da Concussão; XI. Dos que comerceiam ou contraem obrigações incompatíveis com o desempenho de seus deveres; XII. Dos empregados inexatos no desempenho de seus deveres; XIII. Dos empregados imorígeros (sic); XIV. Dos empregados que exercem funções que não lhes competem; XV. Dos funcionários omissos em perseguir os delinquentes e em cooperar para a pronta administração da justiça; XVI. Dos que administram quaisquer efeitos por conta do governo; XVII. [Sem título. Dispões sobre o empregado que não fizer responsável seu subalterno]; XVIII. Dos crimes contra a liberdade, segurança e propriedade individual do cidadão; XIX. Disposições gerais. ACD, sessão de 29 de maio de 1826, tomo I, p. 168-175.
} 
tenham razão suficiente de saberem de seus crimes. 4. Os que são omissos no cumprimento de seus deveres. 5. Os executores de ordens. ${ }^{170}$

O parágrafo quinto causou grande preocupação em alguns deputados, particularmente aqueles advindos da classe militar. Conforme expressou Cunha Mattos, esse parágrafo liquidaria com a disciplina militar, ao tornar responsáveis tanto o oficial que manda quanto o soldado que executa ordens. Segundo o deputado, caso os subordinados hesitassem em obedecer a seus superiores por receio de serem culpados pela execução de determinada ordem, estava instaurada a insubordinação e, por consequência, destruído o princípio de organização das forças armadas.

Tentando tornar o parágrafo melhor definido, foram apresentadas três emendas: uma do deputado Teixeira de Gouvêa que mudava o texto para "os executores de ordens ilegais", outra de Souza França que alterava o dispositivo para "os executores de ordens contrárias à Constituição" e a de Lino Coutinho, que dispunha que "são responsáveis os executores de ordens contrárias à Constituição ou que claudicarem na forma designada por lei". ${ }^{171}$

O debate foi, conforme o editor dos Anais da Câmara dos Deputados, "aturado e renhido" 172 e marcado basicamente por duas posições: uma favorável à matéria tal como disposta no parágrafo original ou em uma de suas emendas; outra, contrária à responsabilização dos executores, mas tão somente dos mandantes.

De forma geral, os defensores da medida apoiavam o direito de resistência de funcionários e cidadãos contra a execução de ordens contrárias às leis e ao sistema vigentes e criticavam de maneira dura a obediência passiva às autoridades. Para eles, os cidadãos eram obrigados a conhecer a letra da lei, particularmente a Constituição, e estarem sempre alertas aos comandos do governo. Lino Coutinho deixou isso bastante claro:

Não se diga que eu quero introduzir a insubordinação, deixando os
executores árbitros das ordens que lhes são dadas pelas autoridades
competentes, todo o cidadão é obrigado a saber de cor as leis (pelo menos
aquelas que reduzidas a uma breve cartilha, formam o código fundamental ou
a constituição). O executor pois, ainda o mais ínfimo, que executar uma
ordem que não venha ornada com todas as cláusulas da lei; o executor que
executar um mandato contra a constituição, contra as garantias individuais
dos cidadãos, bem como seja a segurança de sua pessoa, a inviolabilidade do
seu domicílio, o livre uso de sua religião etc., é pela justiça universal e pela

${ }^{170}$ ACD, sessão de 4 de julho de 1826, tomo III, p. 40.

${ }_{171} \mathrm{ACD}$, sessão de 5 de julho de 1826, tomo III, p. 43.

172 Idem. 
mesma constituição, justiçável por tais execuções; e o cidadão, contra quem se praticarem tais atentados, autorizado para resistir. ${ }^{173}$

O problema apontado por Cunha Mattos, no entanto, ainda persistia: como culpar o soldado pelas ordens dadas pelos oficiais sem quebrar a disciplina militar? Em seu discurso, Coutinho abordou essa questão de maneira que se poderia dizer otimista, mas que permite entrever o entendimento que ele e outros tinham do serviço do soldado.

Afirmou ele:

Tem-se dito que o $\S 5^{\circ}$ podia ser admitido acerca dos executores civis, mas nunca dos militares, que são essencialmente obedientes e passivos. Que é pois um soldado? Será por ventura um autômato mexido por cordéis a belprazer de um comandante? Não será cidadão ou não pertencerá à sociedade que o cria e alimenta? Como é pois que se pretende que ele possa impunemente executar ordens arbitrárias contra as garantias individuais de seus concidadãos, consagradas na constituição que igualmente o rege? (...) se ele fosse enfim um corpo sem contato com a cité então diria que o soldado deve ser um cego executor de todas as ordens boas ou más de seu superior e comandante; mas ainda assim estaria ele obrigado a executar ordens contrárias à justiça universal, contrárias aos direitos da natureza? De certo que não. Se um comandante ordenar a um soldado seu a gratuita morte de um cidadão, o incêndio de uma casa, vila ou cidade, o deverá ele fazer? O soldado, Sr. Presidente, como cidadão deve igualmente saber de cor a constituição; deve saber que nem o seu comandante pode dar ordens que ataquem as liberdades e garantias de seus concidadãos e que nem ele as deve executar. (...) embalem-se, portanto, os meninos brasileiros com a constituição: ensine-se-lhes a lei fundamental como se ensina o padre nosso e não teremos então medo nem dos executores e nem da resistência (...). ${ }^{174}$

Essa ideia da resistência legítima e de criar os mais jovens aprendendo com a constituição semelhante a um credo religioso traz em si várias experiências e tradições intelectuais, ao mesmo tempo em que antecipa determinada visão de futuro. A noção de resistência contra as autoridades estabelecidas estava presente tanto na tradição ibérica, a exemplo de Suaréz, como na inglesa, com Locke. A mesma tradição mescla-se então com a experiência revolucionária francesa, em que a lei positiva foi bastante valorizada frente aos costumes, identificados com o conceito de "Antigo Regime". Portanto, a resistência seria legítima não somente contra os abusos à lei natural - como diriam Suaréz e Locke - mas também contra a constituição e a letra das leis - como na revolução. Daí a necessidade de se ensinar às crianças os direitos constitucionais. Isso antecipa certa expectativa de uma sociedade letrada, informada e crítica de seus governantes, numa perspectiva que ficou conhecida por liberal. Aquele que serve às armas, nesse ponto de vista, é antes cidadão que soldado, devendo sempre questionar ordens contrárias às leis positiva e naturais.

\footnotetext{
173 Ibidem, p. 44.

${ }^{174}$ Idem.
} 
A posição contrária ao parágrafo foi expressa por Clemente Pereira ${ }^{175}$ e Cunha Mattos - este último em discurso separado apresentado em 21 de julho. ${ }^{176}$ Argumentaram em sentidos diferentes: o primeiro abordou aspectos gerais enquanto o segundo se focou na questão militar. Clemente Pereira afirmou que passar o parágrafo seria perigoso e imprudente, já que o executor por vezes não poderia entrar "na inteligência dos planos e dos meios" das autoridades e que disso adviriam muitos abusos. ${ }^{177}$ Cunha Mattos, por sua vez, continuou defendendo a obediência plena de todos os militares a seus superiores:

... se se conceder aos militares inferiores o arbítrio de interpretarem as ordens e de as não executarem para não serem responsáveis quando as não acharem conformes às suas opiniões, está de todo perdida a subordinação e entronizada a anarquia entre aqueles que pela sua pronta obediência devem ser os primeiros defensores da pátria. ${ }^{178}$

Para o deputado, eram culpáveis os governos e generais, mas nunca o executor das ordens.

As duas posições não são excludentes, já que Cunha Mattos, como se verá, também considerava fundamental resguardar os direitos dos soldados e considerá-los concidadãos. O mais interessante desse debate é perceber a maneira como estava em disputa o entendimento sobre o serviço militar num país constitucional e as implicações dessas discussões em outras áreas, como no recrutamento. Vejamos, então, de que modo ele era organizado e como foi discutido no período estudado.

\subsection{O recrutamento no I Reinado}

Nesta seção, será abordada a questão do recrutamento a partir de alguns eixos: a discussão parlamentar sobre seus regulamentos e instruções, os abusos contra os cidadãos nessa prática e o emprego de ex-escravos africanos no Exército regular.

\footnotetext{
${ }^{175}$ José Clemente Pereira (1787-1854) era português, bacharel em direito e em cânones pela Universidade de Coimbra. Nas primeiras eleições para deputados, três províncias o elegeram seu representante: Rio de Janeiro, São Paulo e Minas. Viria a ser senador do Império pela província do Pará; conselheiro de Estado; grande dignitário da ordem da Rosa; dignitário da do Cruzeiro e comendador da de Cristo; membro do Instituto Histórico e Geográfico Brasileiro, da Sociedade Auxiliadora da indústria nacional, da sociedade Amante da instrução e do Conservatório Dramático.

${ }^{176}$ ACD, sessão de 21 de julho de 1826, tomo III, p. 277-278.

${ }^{177}$ ACD, sessão de 5 de julho de 1826, tomo III, p. 45.

${ }^{178}$ ACD, sessão de 21 de julho de 1826, tomo III, p. 278.
} 
O primeiro aspecto que deve ser ressaltado nesta apresentação do recrutamento é a inexistência de um sistema geral que o organizasse. A constituição imperial em seu artigo 150 previa a criação de uma ordenança para regular "Organização do Exército do Brasil, suas Promoções, Soldos e Disciplina". Contudo, durante todo o período estudado, a Câmara sequer iniciou o trâmite do único projeto apresentado para tal fim. ${ }^{179}$ Igualmente, houve somente um projeto que propunha regulamentar por completo a prática e o sistema do recrutamento, mas que também não chegou a ser votado. ${ }^{180}$

As normas vigentes nesse período que regulavam o recrutamento eram as leis de 10/12/1570, 29/08/1640 e de 20/02/1708, a provisão do Conselho Ultramarino de 05/11/1728, o alvará de 16/03/1763, o regulamento de infantaria de 1763 e as instruções de 10/07/1822. ${ }^{181}$ Apesar da multiplicidade, as instruções de 1822 teriam papel mais significativo em orientar os responsáveis pelo recrutamento e tramitaram na Câmara como projeto de lei, em 1827. No debate de seus artigos, muitas questões foram levantadas, apresentando o ponto de vista dos deputados sobre as classes mais úteis ao Estado, algumas perspectivas morais sobre a organização familiar, quem deveria servir e por quanto tempo. A aprovação dessa lei foi vista por muitos como um grande remédio aos males e abusos que os cidadãos do Império estavam sofrendo sob o jugo dos recrutadores. Por essa razão e importância, deter-nos-emos numa análise mais minuciosa de tais instruções.

\subsubsection{As instruções de julho de 1822}

As instruções de 10 julho de 1822 foram editadas pelo então regente Pedro I para marcar os modos pelos quais se deveriam realizar o recrutamento e preencher as fileiras das tropas estacionadas no Rio de Janeiro no contexto da guerra de independência. O príncipe ordenava que se recrutasse, mas "sem detrimento das Artes e Navegação, Comércio e Agricultura, fontes da prosperidade pública”, de modo que seriam "alvos" dos recrutadores aqueles "que sem por nenhuma pública ocupação ou legal indústria, viveiros de criminosa ociosidade, só lhes servem de impedimento [desta mesma prosperidade]".

\footnotetext{
${ }^{179}$ Projeto do deputado Cunha Mattos apresentado em 1828. ACD, 1828, tomo I.

${ }^{180}$ Projeto do deputado Cunha Mattos apresentado em 1827. ACD, 1827, tomo IV.

${ }^{181}$ Cf. Relatório da comissão de guerra apresentado na sessão de 21 de maio de 1830 . ACD, tomo I, p. 183-184.
} 
Em dezoito artigos, as instruções marcariam aqueles que deveriam ser recrutados, mas, mais importante, aqueles que não poderiam ser conscritos, levando alguns a afirmarem que se tratava da "lei do não recrutamento". ${ }^{182}$ Ao longo do Império, essas diretrizes sofreram várias alterações, aumentando o número de isenções. Contudo, no I Reinado, sua forma seria muito similar à original, editada por Pedro I. Assim, para fins de análise, iniciaremos pelas orientações originárias e depois passaremos às modificações feitas na Câmara dos Deputados. Mandou o príncipe:

I. S.A. Real há por bem ampliar por mais um mês a disposição do Decreto de 30 de janeiro deste ano, porque concede servirem somente por 3 anos os indivíduos que sentarem praça voluntariamente nos corpos de $1^{\mathrm{a}}$ Linha; este prazo será contado desde o dia do afixamento dos Editos, ou na Corte ou nos Distritos cujos comandantes deverão participar o Quartel General o dia em que os afixarem; II. Concluído o determinado prazo, proceder-se-á logo ao recrutamento no qual serão compreendidos os indivíduos das classes abaixo declaradas. III. Ficam sujeitos ao recrutamento todos os homens brancos solteiros e ainda pardos libertos de idade de 18 a 35 anos que não tiverem a seu fazer as exceções de que logo se tratará. IV. Os caixeiros de lojas de bebidas e tabernas sendo solteiros e de idade até 35 V. Os milicianos impropriamente alistados e que não estiverem fardados ou não subsistirem de uma honesta e legal indústria. VI. São isentos do recrutamento os homens casados; o irmão de órfãos, que tiver a seu cargo a subsistência e educação deles; o filho único de lavrador ou um a sua escolha quando houver mais de um, cultivando terras ou própria ou aforadas ou arrendadas. VII. O artigo acima se estende do mesmo modo ao filho único de viúvas. VIII. São também isentos o feitor ou administrador de fazendas com mais de seis escravos, ou plantação ou de criação ou de olaria; IX. Os tropeiros, boiadeiros, os mestres de ofícios com loja aberta, pedreiros, carpinteiros, canteiros, pescadores de qual discrição, uma vez que exercitem os seus ofícios efetivamente e tenham bom comportamento. $\mathrm{X}$. No dito artigo ficam compreendidos os mais ofícios fabris, debaixo da condição designada; igualmente em cada cocheira pública não poderá haver mais de oito bolieiros, conforme o número das seges que tiverem: nas casas de particulares, que tiverem mais de duas seges, dois; e um nas que tiverem de uma até duas; e a fim de que não haja nisso abuso, o Intendente Geral da Polícia mandará logo fazer um alistamento geral dos bolieiros das cocheiras públicas e passar aos que forem compreendidos um certificado, que valerá enquanto eles estiverem no serviço das ditas cocheiras; os moços das cocheiras de cavalos de aluguel não são compreendidos na presente isenção; XI. Os marinheiros, grumetes e moços que se acharem embarcados ou matriculados; os arrais efetivos de barcos de conduzir mantimentos ou outros gêneros.

XII. Ficam isentos também do recrutamento nas casas de comércio de grosso trato de três caixeiros, nas de segunda ordem, dois, na de pequena, um. XIII. Esta isenção acima será igualmente aplicada em toda a sua extensão às casas de comércio estrangeira. XIV. Todos os estudantes que apresentarem atestados dos respectivos professores, que certifiquem a sua aplicação e aproveitamento. XV. Os comandantes dos distritos irão remetendo ao Quartel General

182 Apud MENDES, Fábio Faria. A economia moral do recrutamento militar no Império do brasileiro. Revista Brasileira de Ciências Sociais, vol. 13, nº 38. 
sucessivamente os recrutas que se forem apurando, acompanhados de competente escolta para sua guarda, sem que jamais empreguem correntes, algemas ou manilhas. XVI. Os recrutas virão acompanhados de duas relações indicativas de suas circunstâncias e assinadas pelos respectivos comandantes dos distritos; uma para a Secretaria de Estado da Guerra e outra entregue no Quartel General, e nesta declaração, o dia em que as escoltas partem do distrito. XVII. A cada uma das praças de que se compuser a escolta, se abonará pela Tesouraria Geral das Tropas da Corte, 80 réis diários contados desde o dia em que saírem dos Distritos até aquele em que a eles regressarem, a vista do seu itinerário pelo qual se fará a conta na mesma Tesouraria Geral das Tropas leva o visto do Quartel General. Os recrutas, porém serão também abonados 60 réis diários até o dia de sua apresentação no Quartel General. XVIII. Feito o recrutamento para a $1^{a}$ Linha, procederão imediatamente os comandantes dos distritos a um exato alistamento, sem exceção de pessoa, de todos os indivíduos dispensados do recrutamento: formalizarão duas relações nominais e declaratórias das posses, circunstâncias e idades; uma dos que devem servir na $2^{\mathrm{a}}$ Linha e outra dos que estão em circunstância de passarem para as Ordenanças; e as remeterão à Secretaria de Estado da Guerra para que, sendo aprovadas, se expeçam ordens para se lhes fazer os convenientes assentos de Praças. ${ }^{183}$

Essas instruções elucidam a dupla intenção do recrutamento nesse período: preencher as fileiras do Exército e tornar úteis para a sociedade grupos considerados desocupados ou "vadios", elementos potencialmente perigosos para o reino. Por meio do serviço militar - em teoria - esses "sem ocupação" poderiam aprender a ter disciplina e, mais, tirar o fardo dessa atividade das classes úteis para a economia. Isso mostra uma tentativa de direção da sociedade por parte do governo que busca bem alocar seus recursos e conduzir o comportamento social de seus súditos. ${ }^{184}$ Tal como afirmaria, em 1826, Holanda Cavalcante sobre essas indicações:

(...) design[am] com preferência aqueles cidadãos que primeiro são obrigados a tomar as armas em serviço da pátria e procur[am] assim evitar o atropelo de outros cidadãos, que necessários e úteis se fazem a outras diferentes classes da sociedade. ${ }^{185}$

Nesse direcionamento, contudo, o governo contemporizou com alguns interesses e grupos, que se poderia dividir, de modo geral, por motivos de ordem econômica e vulnerabilidade social. Temos assim que de uma ordem geral - recrutar homens brancos e pardos entre 18 e 35 anos - surgiram várias exceções. Os parágrafos VIII, IX, X, XI, XII, XIII trazem isenções de grupos voltados diretamente para a produção ou prestação de serviços e que, aparentemente, o governo considerava importantes o suficiente para resguardá-los do serviço das armas. Já os pontos VI e VII isentavam homens patres

\footnotetext{
${ }^{183}$ BRASIL. Coleção de leis do Império, ano de 1823, tomo III, p. 56-58.

${ }^{184}$ COSTA, Fernando Dores. O bom uso das paixões: caminhos militares na mudança do modo de governar. Análise Social, vol. XXXIII (149), 1998 (5º.

${ }_{185}$ ACD, sessão de 14 de julho de 1826, tomo III, p. 173.
} 
familias, responsáveis pela condução e pela “economia” (oeconomia) do lar. Retirá-los significaria retirar a cabeça da casa e lançar seus parentes - os irmãos órfãos ou a mãe viúva - em grandes dificuldades de subsistência.

Assim, observa-se que o recrutamento era tensionado por diversos fatores políticos, econômicos e sociais - e que estes o influenciaram em sua formatação muito mais do que considerações de eficiência militar, ao menos no tocante ao referido conjunto de instruções. ${ }^{186}$

Também é importante ressaltar o parágrafo XV. Nele, o governo instrui os comandantes responsáveis pelo recrutamento a enviar os recrutas para o Quartel General da Corte com escolta, mas sem algemas, correntes ou manilhas, ou seja, sem submeter-lhes a tratamentos tipicamente de prisioneiros e de escravos. Os recrutas, apesar de serem obrigados a servir, não deveriam ser coagidos dessa forma no caminho ao assentamento de praça. Tem-se aqui a tentativa do governo do regente de se descolar de uma imagem de violência que, nos quadros de um mundo constitucional nascente, estava associada ao governo anterior e que perdia suas bases de legitimidade. ${ }^{187}$

Sabe-se que era a prática coeva fazer recrutas dessa forma, lançando mão dos mais diversos expedientes de violência e coação. Assim era a rotina do Exército na América portuguesa e no Reino luso e que permaneceu como prática - tanto quanto a pesquisa permite afirmar - durante o Primeiro Reinado, apesar das mais expressas determinações do governo e do Parlamento em contrário.

Temos, portanto, a preocupação dos poderes Executivo e Legislativo em resguardar os cidadãos do então reino do Brasil de maus tratos no recrutamento, preocupação que se estenderá para o período posterior.

Tendo-se feito esta análise da primeira edição das instruções, podemos passar para os debates feitos sobre elas na Câmara dos Deputados. O projeto apresentado resumia-se em dois artigos: (1) generalizar as instruções ao suprimir os dois primeiros parágrafos e (2) punir aqueles agentes que a desrespeitassem. Sua primeira discussão ${ }^{188}$ se deu em 13 de julho de 1826. Após breve arrazoado sobre a necessidade e utilidade da

\footnotetext{
${ }^{186}$ MENDES, Fábio Faria. Recrutamento militar e construção do Estado no Brasil Imperial. Belo Horizonte: Argvmentvm, 2010, p. 33.

${ }^{187}$ COSTA, Fernando Dores. Insubmissão. Dissertação de doutoramento: Universidade Nova de Lisboa, 2006, p. 166.

${ }^{188}$ A primeira discussão refere-se ao mérito da matéria como um todo. Na segunda leitura são discutidos cada um dos artigos da lei e as emendas apresentadas são analisadas. Na terceira, define-se o projeto final, com mais uma discussão minuciosa de seus artigos.
} 
lei naquele momento, o deputado Cunha Mattos a defendeu e afirmou que ela era um grande avanço em relação ao que era praticado. Conforme seu relato:

\begin{abstract}
A maneira de se fazer o recrutamento no Brasil era darem os govenadores ordens pra prender os homens e ordinariamente escolhiam a noite do Natal, festa do Espírito Santo etc. para fazer estas prisões em que pegavam a todo o mundo, como homens casados, fazendeiros etc. os quais eram metidos em casas fechadas e, à medida de proteção que havia, ou amizade com os ajudantes de ordens, uns saíam para a rua, e os mais infelizes e desgraçados que muitas vezes não estavam nas circunstâncias de serem recrutados eram os que ficavam alistados. (...) Logo depois apareceram as instruções de 10 julho de 1822 fundadas em princípios mui sábios (...) [e] resultaram grandes benefícios e livraram a muitos homens da opressão, do flagelo e ainda melhor efeito teriam, [se] literalmente praticadas. (...) O motivo que tive [para fazer o projeto] foi para obstar que os desgraçados cidadãos do Brasil fossem tratados como escravos quando são remetidos para esta Corte, pois vêm acorrentados e de gargalheira, não há lei mais santa, mais justa, mais saudável, do que a destas instruções. ${ }^{189}$
\end{abstract}

Embora a descrição oferecida por Cunha Mattos quanto ao recrutamento soe um tanto exagerada, ver-se-á que algo similar à situação aconteceu em Minas Gerais no feriado de Corpus Christi no mesmo ano. Quanto à defesa acalorada das instruções, pode-se perceber o quanto eram vistas como panaceia aos problemas de maus tratos que ocorriam por ocasião dos vários recrutamentos pelos quais passou o país. Isso porque, para os parlamentares, as práticas corriqueiras que a lei tentava coibir feriam os direitos dos cidadãos estabelecidos no artigo 179 da Constituição. Como afirmou Lino Coutinho:

\begin{abstract}
Um negócio em que se acha comprometida tão de perto a segurança individual do cidadão, não merecerá os cuidados dos representantes da nação? Deixaremos que esses capitães mores, governadores de lugares, e mesmo de armas, continuem no arbitrário exercício de oprimir os desgraçados cidadãos, agarrando a torto e a direito os casados, os filhos de viúvas, os irmãos de órfãs, e que vergados debaixo de ferros sejam piores que bestas enviados ao depósito? Cuidemos quanto antes com os nossos decretos em reprimir a maldade e o atrevimento de semelhantes recrutamentos, façamo-los responsáveis pela transgressão, que eles até agora não conhecem, quando se trata de recrutamento, e mostremos aos nossos concidadãos, que punimos por seus direitos $(\ldots.){ }^{190}$
\end{abstract}

Havia, assim, um grande esforço, ao menos na Câmara dos Deputados, em estabelecer regras claras para respeitar os novos direitos individuais e de responsabilizar os funcionários que os desrespeitassem, ou seja, tratava-se de consolidar e reforçar o governo constitucional, baseado nos direitos individuais dos cidadãos. Tem-se aqui o entendimento de que o direito poderia e deveria ser utilizado para transformar as

\footnotetext{
${ }^{189}$ ACD, sessão de 13 de julho de 1826, tomo III, p. 161.

${ }^{190}$ Ibidem, p. 162.
} 
práticas do recrutamento, remetendo à ideia apresentada no primeiro capítulo acerca do aspecto constitutivo das leis.

A tramitação do projeto de lei foi longa. Por todo o ano de 1826, ele foi ampla e profundamente discutido. Os principais problemas levantados, e aqui destacados, são: a questão do tempo de serviço, as distinções entre voluntários e forçados e o recrutamento de estrangeiros africanos.

Em 3 de agosto, iniciou-se a segunda discussão do projeto. Logo que se principiou o debate, o deputado Vasconcelos ${ }^{191}$ propôs que nessa lei ficasse definido o tempo de serviço de recrutas forçados e de voluntários, embora seu objeto versasse sobre o modo de se realizar o recrutamento e não sobre o tempo de serviço, como pungentemente assinalou o deputado Cavalcanti de Albuquerque. ${ }^{192}$ Seja como for, Vasconcelos propôs uma emenda ao projeto que propunha o tempo de quatro anos para o voluntário e seis para o forçado, e completava: "que o governo cumpra religiosamente a sua palavra". ${ }^{193}$ Tendo sido apoiada, a discussão continuou nesse tema. Duas foram as principais posições acerca da proposta: uma que endossava a necessidade de distinção entre forçados e voluntários e outra que negava a necessidade ou mesmo sua conveniência. Não obstante, todos os deputados que se pronunciaram emitiram suas opiniões sobre o valor do serviço voluntário e do ideal de serviço do soldado.

Os argumentos utilizados por aqueles que defendiam a diferença entre forçados e voluntários se resumia a premiar aqueles que se dispunham a servir. Ao premiá-los, pensavam eles, as fileiras do Exército estariam cheias de homens dispostos e animados ao serviço, seria um incentivo para tornar o serviço das armas mais atrativo e o

\footnotetext{
${ }^{191}$ Nasceu em Ouro Preto, capital de Minas Gerais, em 27 de agosto de 1795, e faleceu no Rio de Janeiro em 1 de maio de 1850. Foi para a universidade de Coimbra em 1813 e fez o curso de direito em que foi graduado bacharel em 1818. Depois de passar um ano em Portugal, entrou para o serviço da magistratura com a nomeação de juiz de fora de Guaratinguetá, e posteriormente foi nomeado desembargador da relação do Maranhão. Foi eleito deputado repetidas vezes por Minas Gerais desde a primeira legislatura, até que em 1838 foi eleito senador. Foi ministro da fazenda em 1831, da justiça em 1837, e do império em 1840. Foi ainda conselheiro de Estado. Era grã-cruz da ordem do Cruzeiro, e também da Legião de Honra da França.

${ }^{192}$ Disse ele: "Sr. Presidente, nesta lei não tem lugar tal matéria. Que nos propomos fazer? Estabelecer o método para o recrutamento: logo nada temos com o soldado que não é recrutado nem com o tempo que ele deve servir: isto é objeto de outra lei". Embora o problema do tempo de serviço fosse urgente à época, encaixá-lo no texto das instruções pode indicar uma certa confusão na maneira de lidar com o recrutamento, já que, como dito, é uma instituição perpassada por muitas questões diferentes, ou ainda um amadorismo com a produção legislativa, uma vez que esse era o primeiro ano de funcionamento do Parlamento, após a breve Constituinte.

193 ACD, sessão de 3 de agosto de 1826, tomo IV, p. 18.
} 
recrutamento mais barato e menos traumático. ${ }^{194}$ Como deixou bem claro o deputado Lino Coutinho:

(...) se não deve marcar pela mesma bitola o homem agarrado à força e aquele que se entrega voluntariamente para servir. Ninguém, Sr. Presidente, há de negar a justiça e a verdade desta distinção para separar um benemérito, que vai pegar nas armas por sua própria vontade, daquele que é obrigado pela força. O voluntário deve ser mais protegido, deve ser visto com outros olhos bem diversos daqueles com que se encara o soldado recrutado; se isto não for assim, qual há de ser o homem que quererá ser espontaneamente soldado? E o resultado é, que teremos sempre um Exército de recrutas, ou em frase mais verídica, um exército de forçados. E qual será a distinção que devemos dar ao voluntário, se não, além da estima, a diminuição do serviço? O cidadão, neste caso, sabendo que tem de trabalhar a metade do tempo, daquele a que é obrigado o recruta, virá de bom grado oferecer-se. ${ }^{195}$

A principal crítica feita por esses deputados ao sistema vigente - que já distinguia voluntários de forçados com menos tempo de serviço - referia-se ao descumprimento das promessas feitas pelo governo ao primeiro grupo. Conforme argumentaram, havia poucos voluntários porque não havia confiança no governo em cumprir sua parte do contrato. ${ }^{196}$ Para tais deputados, então, se os cidadãos pudessem confiar no governo "e nas determinações das leis, nunca faltar[iam] homens para o serviço da nação". ${ }^{197}$ A fim de evitar os arbítrios do governo, Lino Coutinho chegou mesmo a propor uma emenda radical que permitiria aos soldados abandonar as fileiras caso seu tempo houvesse expirado e seu comandante se negasse a conceder a dispensa. A proposta, posto que derrotada, é indicadora do grau com que alguns deputados estavam dispostos a defender os direitos individuais dos soldados. Os efeitos dessa emenda, caso tivesse sido aprovada, teriam sido devastadores sobre o Exército naquele

\footnotetext{
194 “(...) porque favorecendo os voluntários e convidando-os com esta distinção [de servir menos tempo], evitaremos ou ao menos minoraremos as violências e barbaridades que se praticam com aqueles que vêm obrigados para a praça." Discurso do deputado Vasconcelos, sessão de 3 de agosto de 1826, tomo IV, p. 25. As novas formas de incentivo ao serviço militar, como a honra, serão melhor analisdas no capítulo seguinte. Cf. COSTA, Fernando Dores. O bom uso das paixões: caminhos militares na mudança do modo de governar. Análise Social, vol. XXXIII (149), 1998 (5º.

195 Ibidem, p. 21.

${ }^{196}$ Conforme afirmou Lino Coutinho: "Mas o que é para desejar é que o governo cumpra tudo quanto se tiver legislado e tudo quanto ele tiver prometido. Promete-se que o soldado terá baixa dentro de três ou quatro anos, porém quantas vezes se tem guardado esta promessa? Ora, é duro, é bárbaro, que tendo-se verificado a condição deste contrato, continue o cidadão a jazer no cativeiro, e por um indeterminado tempo a arbítrio do governo ou do seu chefe! O soldado quando entra na linha do exército forma um verdadeiro contrato com o governo dizendo - eu me alisto para servir tantos anos, findos os quais não terei mais obrigação de ficar unido a estas bandeiras". ACD, sessão de 3 de agosto de 1826, tomo IV, p. 21.

${ }^{197}$ Cunha Mattos, ACD, sessão de 3 de agosto de 1826, tomo IV, p. 21.
} 
momento, tanto em termos de números de combatentes que sairiam do serviço, quanto na manutenção da hierarquia militar. ${ }^{198}$

O posicionamento de outro grupo de deputados, minoritário, mas importante, propunha verdadeira mudança às práticas coevas. Seu principal argumento provinha do artigo 145 da Constituição imperial em que se lia: "Todos os Brasileiros são obrigados a pegar em armas, para sustentar a Independência e integridade do Império, e defendê-lo dos seus inimigos externos, ou internos". Sendo obrigação de todos os cidadãos do Império lutar para defendê-lo, não caberia a divisão entre soldados. Conforme se expressou o já citado Cavalcanti de Albuquerque:

Falando, porém, novamente sobre a diferença que se quer fazer de voluntários e não voluntários, insisto que ela é impolítica e prejudicial. Segundo a minha opinião nenhuma contemplação devem ter os voluntários. Eu sentei praça voluntariamente, Sr. Presidente, e nem por isso me julgo com maior merecimento do que os outros que não são voluntários. (...) Nós nos devemos lembrar que o serviço militar é ônus que pesa sobre todos os membros da sociedade igualmente e que por isso deve recair sobre todos, à exceção somente daqueles que por justificados motivos não podem ser empregados nas armas. Como pois se hão de conceder privilégios àquele que cumpre com a sua obrigação? (...) Disse que essa classificação era impolítica e por consequência prejudicial. E certamente lançar sobre aqueles que professam um emprego todo de honra e brio a nota de recrutados e obrigados é tirar-lhes metade do seu valor. O recrutamento nunca poderá servir de nódoa ao soldado. Muitos dos que têm sido conduzidos a ferros para a praça têm mostrado em todo o tempo ser tão capazes e tão dignos dos uniformes como os voluntários. Se me disserem que o voluntário merece mais atenção por isso que livremente se sujeita à lei quando o outro é forçado, responderei que este vindo obrigado e muitas vezes preso, sofre neste trato um castigo não pequeno e por ele tem pago sua rebeldia. ${ }^{199}$

O deputado Almeida e Albuquerque, igualmente contrário à distinção entre voluntário e forçado, propôs outra, a saber: diferenciar homens considerados úteis ao Estado dos "vadios e ociosos". Disse ele:

\footnotetext{
${ }^{198}$ No texto da emenda, lê-se: "Os que assentarem praça voluntariamente servirão 3 anos e os que forem recrutados, 6 anos. No fim destes prazos se darão imediatamente tanto ao voluntário como ao recrutado as suas escusas: se o comandante do regimento ou batalhão for remisso em passar as ditas escusas, esses indivíduos poderão largar os seus corpos, havendo entregado pontualmente o seu armamento e obrigar pelas autoridades superiores ao dito seu comandante a passar-lhes as suas escusas". O texto foi rechaçado em seguida pelo deputado Cavalcanti de Albuquerque que asseverou: "Quer o Sr. Lino Coutinho que em o soldado tendo acabado o seu tempo e não lhe querendo o seu superior dar a sua escusa do serviço, possa ele retirar-se, entregando o seu armamento. Isto é fomentar a insubordinação na tropa. O soldado, tendo finalizado o tempo de praça, deve requerer baixa ao seu chefe e às autoridades competentes, e não deve dizer - como já acabei o meu tempo, quero ir para minha casa". Ou como colocou o deputado Almeida e Albuquerque: "Pretende um nobre deputado que ao soldado voluntário se deve entregar sua escusa no ato do alistamento e que, findo o seu tempo de serviço possa ele retirar-se imediatamente do Exército. Se assim acontecesse, não seria de admirar se se visse desaparecer, voar em um momento, exércitos inteiros". ACD, sessão de 3 de agosto de 1826, tomo IV, p. 19; 22.

${ }^{199} \mathrm{ACD}$, sessão de 3 de agosto de 1826, tomo IV, p. 23.
} 
Eu só admitiria diferença entre o soldado que tivesse alguma ocupação e soubesse alguma arte útil, e aquele que não possuísse essa qualidade, porque o primeiro saindo das armas vai ser um cidadão muito útil ao estado e este facilmente se pode entregar à ociosidade. (...) Esta distinção é tanto mais necessária por isso mesmo que muitos dos nossos soldados são arrancados das suas lavouras e dos seus ofícios, quanto todas as províncias abundam de vadios e ociosos que nem sabem, nem querem ofício ou ocupação alguma, e estes podem, e devem, servir muito mais tempo do que aqueles. ${ }^{200}$

Temos assim uma proposta nova e bastante interessante pela interpretação que faz da Constituição. Isso porque, embora o deputado não negue que a todos recaia a obrigação de defender o Império, propõe a distinção da soldadesca a partir do princípio da utilidade, ou seja, pelos benefícios que os homens traziam à sociedade antes de entrar nas forças armadas. Aqueles que fossem mais úteis deveriam servir menos tempo; os que fossem menos úteis, mais. É uma tentativa de hierarquizar e, portanto, de discriminar, os soldados, mantendo, no entanto, o princípio geral da igualdade do serviço. Também é notável o fato de que Cavalcanti de Albuquerque, tendo servido como voluntário, não fosse favorável à distinção de que ele mesmo gozou. Isso indica a complexidade do sistema político imperial e como a votação, a orientação e formação de grupos dentro da Câmara dos Deputados nos primeiros anos legislativos era fluida e mutável. ${ }^{201}$

Em termos gerais, a proposta de recrutar a todos sem distinção de serviço parece apontar para um sistema mais equalizado - e poder-se-ia dizer "moderno" - em sua distribuição do "imposto de sangue". Não se deve contrapor, contudo, essa defesa de "progresso" rumo a um Exército profissional à outra de um sistema "atrasado", ou, poder-se-ia dizer, o "futuro" anunciado a um "resistente passado". Pode-se observar isso nas próprias falas elencadas. Cavalcanti de Albuquerque mostra sua complacência com o sistema de recrutamento que utiliza ferros e correntes para trazer os recrutas como uma espécie de punição por sua "rebeldia" - uma prática considerada abusiva por seus colegas deputados e contra os direitos estabelecidos na Carta imperial - e, por outro lado, é perceptível na proposta de Almeida e Albuquerque um sistema segregatício que vai contra a própria ideia de igualdade entre cidadãos que ele toma por base como argumento.

Com o que ambos os grupos concordavam era a punição aos agentes públicos que se furtassem de executar a lei, de entregar as dispensas ao serviço e de abusar de seu poder no momento do recrutamento - com a exceção apresentada de Cavalcanti de

\footnotetext{
${ }^{200}$ Ibidem, p. 22-23.

${ }^{201}$ PEREIRA, Ao soberano Congresso.
} 
Albuquerque. Tal postura parece sustentar uma preocupação dos representantes em assegurar estabilidade e previsibilidade nas ações governamentais de modo a criar laços de confiança entre Estado e cidadãos, base do que eles entendiam como pacto social e, por conseguinte, de seus direitos e deveres. ${ }^{202}$

Ao término dessa discussão, foi aprovado que na lei se manteria a distinção entre forçados e voluntários; que estes serviriam por seis anos em tempos de paz e quatro em tempos de guerra enquanto aqueles serviriam por dez anos. ${ }^{203}$

A discussão continuou no dia seguinte, a partir do ponto III (art. $3^{\circ}$ ) - "Ficam sujeitos ao recrutamento todos os homens brancos solteiros e ainda pardos libertos de idade de 18 a 35 anos que não tiverem a seu fazer as exceções de que logo se tratará" - e gerou uma grande polêmica.

As desavenças começaram quando Vasconcelos enviou uma emenda que pedia a supressão das palavras "branco e pardo", ao que imediatamente pediu o deputado Holanda Cavalcante que ela entrasse em discussão por não “convir nela”. Em seguida, o mesmo parlamentar propôs outra emenda para que a palavra "homens" fosse substituída por "cidadãos brasileiros". O deputado Paula Souza ${ }^{204}$ foi o primeiro a se expressar sobre a gravidade da distinção apresentada na emenda de Cavalcante:

É necessário tomar em muita consideração o que acaba de dizer o nobre deputado, que não quer que sejam - homens - mas cidadãos - a razão parece que é esta. Como há muitos estrangeiros, por isso quer o nobre deputado prevenir que não sejam recrutados, dizendo - cidadãos brasileiros - isto merece muita consideração. ${ }^{205}$

A emenda de Holanda Cavalcante não era simples. Não se tratava da exclusão de estrangeiros, num sentido amplo. Pela análise dos discursos proferidos, sua proposta parecia se destinar a um grupo de estrangeiros que não havia chegado ao Brasil por vontade própria: os africanos libertos. Isso parece ficar mais evidente pelo momento em

\footnotetext{
${ }^{202}$ Como disse Almeida e Albuquerque: "O cidadão que evita o recrutamento não comete crime algum para ser castigado, se ele foge e esconde-se é porque reconhece que nada do que se the promete se lhe há de guardar; é porque está convencido pela prática que nenhuma das garantias que lhe prometem as leis e a constituição se cumprem em sua defesa e em defesa dos seus bens; é finalmente, porque a sociedade não satisfaz da sua parte as obrigações para com ele". ACD, sessão de 3 de agosto de 1826, tomo IV, p. 28.

${ }^{203}$ Ibidem, p. 30.

${ }^{204}$ Francisco de Paula Souza e Melo nasceu na vila de Itu, na Província de São Paulo, em 5 de junho de 1791 e faleceu na Província do Rio de Janeiro em 16 de agosto de 1852. Foi eleito deputado à Assembleia Constituinte e foi deputado nas duas primeiras Legislaturas ordinárias, de 8 de maio de 1826 a 3 de setembro de 1829 e de 3 de maio de 1830 a 5 de outubro de 1833. Presidente da Câmara dos Deputados de 4 de maio a 2 de junho de 1827 e escolhido pela Regência para o cargo de senador pela Província de São Paulo a partir de 17 de agosto de 1833. Também foi convidado por Pedro II a formar um gabinete a 31 de maio de 1848 .

${ }^{205} \mathrm{ACD}$, sessão de 4 de agosto de 1826, tomo IV, p. 35.
} 
que ofereceu sua emenda, qual seja, logo após a proposta de Vasconcelos de retirar as palavras branco e pardo. Se os parlamentares anuíssem a essa ideia, as diferenças de origem e de cor não importariam.

Vasconcelos continuou o debate retrucando imediatamente que era melhor utilizar-se de estrangeiros e poupar os "braços brasileiros" - posição da qual viria a se afastar em 1828 - enquanto Lino Coutinho ironizou:

\begin{abstract}
Perguntarei se esta lei não é para cidadãos brasileiros? Creio que ninguém nisto poderá ter dúvida, logo sobre quem vem a recair? Sobre os cidadãos brasileiros. Como pois será preciso declarar que é para cidadãos brasileiros? Nós poderemos fazer uma lei de recrutamento para os estrangeiros, para um inglês, um alemão, um suíço? Nós fazemos leis para as outras nações ou para os cidadãos brasileiros? É coisa célebre! (...) A questão é se deve substituir a palavra - cidadão - à palavra homem. A palavra homem é termo genérico e a palavra cidadão não é genérico e por isso não é necessário ir na lei porque se sabe que a lei é para todo o cidadão brasileiro. ${ }^{206}$
\end{abstract}

Essa associação entre "homens" e "cidadãos" feita por Coutinho pode ser encarada ou como uma "ingenuidade" ou como um jogo político sagaz, uma vez que se a lei passasse com o termo genérico de "homens", as interpretações posteriores poderiam ser bastante amplas, podendo incluir os africanos libertos e demais estrangeiros. Seja como for, o deputado Clemente Pereira tornou o objeto mais claro logo em seguida:

(...) eu creio que é desnecessária essa [emenda] que quer tirar o termo -
homem - e substituir-lhe o termo - cidadão - e mesmo creio que não pode ter
lugar nenhum, porque os libertos, ainda que não sejam nascidos aqui, ainda
nascidos na Costa da África, apesar de não serem cidadãos, ficam sujeitos ao
recrutamento. Por consequência não se pode usar do termo - cidadão. (...)
Nenhum estrangeiro está sujeito às leis do país, salvo as leis da polícia, as
outras não o obrigam de maneira nenhuma. Logo está muito claro que não
pode esta lei recair sobre os estrangeiros. Seria talvez melhor dizer -
brasileiros solteiros - mas - cidadãos - oponho-me, por isso que os libertos
podem também entrar no recrutamento. ${ }^{207}$

A emenda de Holanda Cavalcante foi posta em votação e aprovada, o que levou a uma profusão de discursos inflamados e a uma rodada de exegeses constitucionais sobre quais eram os limites dos direitos dos ex-escravos africanos dentro do Estado imperial.

De modo geral, duas posições transpareceram nesse debate: aqueles que eram contra o recrutamento de africanos libertos e aqueles a favor. São exemplos da primeira posição, além do já citado Holanda Cavalcante, os deputados Almeida e Albuquerque e

\footnotetext{
206 Idem.

${ }^{207}$ Ibidem, p. 35-36.
} 
Maia. ${ }^{208}$ Esses parlamentares não foram muito prolíficos em seus discursos, mas seu principal argumento resume-se em interpretar a Constituição da seguinte maneira: onde nela estava escrito "brasileiro", dever-se-ia ler "cidadão brasileiro". Tal interpretação faria com que o artigo $145^{209}$ da Constituição excluísse a participação de não-cidadãos do serviço militar. Como disse o deputado Almeida e Albuquerque: "De mais este termo - brasileiros - tomou-se promiscuamente, como se dissesse - cidadãos brasileiros - e tanto faz a palavra - brasileiros - como - cidadãos brasileiros - tudo é o mesmo". ${ }^{210}$ Ao que então concluiu Maia:

Eu acho que a emenda do Sr. Cavalcanti está muito bem vencida: o africano sempre fica africano e por isso que deve declarar que só são sujeitos ao recrutamento os cidadãos brasileiros, porque estes é que têm obrigação de defender o império do Brasil. ${ }^{211}$

O segundo grupo de deputados era formado por Vasconcelos, Lino Coutinho, Clemente Pereira e Ferreira França. ${ }^{212} \mathrm{O}$ argumento utilizado pelos três primeiros ia de encontro ao dos parlamentares anteriores e baseava-se numa interpretação constitucional que diferenciava "brasileiro" de "cidadão brasileiro". Afirmou Coutinho: “a constituição diz - todos os brasileiros são obrigados a pegar em armas para sustentar a independência da pátria - e nós temos brasileiros que, contudo não são cidadãos, portanto, votou-se contra o espírito e a letra da constituição". ${ }^{213}$

Ferreira França, por outro lado, fez um discurso bastante intrigante e se destacou dos demais. Ele associou a alforria do escravo à naturalização, ainda que o escravo fosse africano. Isso significava, em última, a aquisição dos direitos de cidadão, mesmo que somente os civis:

O primeiro artigo da constituição diz - O império do Brasil é a associação política de todos os cidadãos brasileiros - por consequência onde nela se diz brasileiros está entendido que é cidadãos brasileiros, pois estes é que são obrigados a tomar armas pela pátria, nisto não pode haver dúvida nenhuma, e

\footnotetext{
${ }^{208}$ Natural da cidade do Porto, nasceu em 6 de outubro de 1789, e faleceu no Rio de Janeiro em 3 de outubro de 1853. Foi bacharel em direito, deputado na Constituinte brasileira e nas duas primeiras legislaturas por Minas Gerais, senador do império pela província de Goiás, conselheiro de Estado ordinário, membro do Instituto Histórico e Geográfico Brasileiro, grande dignitário da ordem da Rosa, comendador da de Cristo, cavaleiro da do Cruzeiro.

209 "Todos os Brasileiros são obrigados a pegar em armas, para sustentar a Independência, e integridade do Império, e defende-lo dos seus inimigos externos ou internos."

${ }^{210}$ ACD, sessão de 4 de agosto de 1826 , tomo IV, p. 36.

211 Ibidem, p. 37.

${ }^{212}$ Filho de Joaquim Ferreira França e de Anna Ignacia de Jesus França, nasceu na cidade da Bahia em 14 de janeiro de 1771 e faleceu na mesma cidade em 9 de março de 1848 . Formou-se pela Universidade de Coimbra em três cursos - medicina, matemática e filosofia. Foi deputado na Constituinte brasileira e em três legislaturas subsequentes. Foi médico de dom Pedro I.

${ }^{213}$ ACD, sessão de 4 de agosto de 1826, tomo IV, p. 36.
} 
portanto a proposição de alguns senhores que dizem que a palavra brasileiros faz diferença de cidadãos brasileiros não pode ter lugar. Muitos há que, sendo nascidos no Brasil, não são cidadãos, mas destes não fala a constituição, ou não os compreende debaixo da palavra brasileiros; porque eles não formam a associação política do império do Brasil, nem por consequência são obrigados a pegar em armas para defender o mesmo império (...). Disse-se que a constituição determina que os libertos peguem também em armas para defender o império. Sim, senhores: mas o que são os libertos? Os libertos são cidadãos brasileiros: o que quer dizer - libertos? Parece que quer significar aqueles que não nascendo livres adquiram a sua liberdade: a expressão libertos - é neste caso análoga a - naturalizados - porque não importa que seja nascido aqui ou acolá, liberto é todo aquele que, até certo tempo sendo nosso escravo, não o é mais, e tornou-se naturalizado, só pela aquisição da liberdade, porque eles perderam seu país e a não serem cidadãos daqui, donde é que são? Serão do ar? A que associação pertencem? Esta é boa! Por consequência quando a constituição diz que os brasileiros devem pegar em armas para defender a pátria entende-se - cidadãos brasileiros - o liberto que, tendo sido nosso escravo, passou a não ser, e entre depois de livre no gozo de todas as fruições, segundo a lei, tanto mais porque ele sofreu todos os vexames do seu estado anterior; nisto eu creio que não pode haver nenhuma dúvida. $^{214}$

A interpretação de França apresentou uma perspectiva inovadora. Poder-se-ia classificá-la como um "lance" na linguagem e no discurso político da época, ${ }^{215}$ embora não tenha tido maiores consequências imediatas. A associação entre liberdade e naturalização e, por consequência, cidadania passiva, tornava todo escravo africano um potencial cidadão.

Essa discussão é prolífica em vários sentidos. Ressaltar-se-á, contudo, dois: em primeiro lugar, pelo debate racial que a embasa e, em segundo, pela continuidade das “disputas" acerca de quem compunha o corpo de cidadãos após a outorga da Constituição.

$\mathrm{O}$ artigo $3^{\circ}$ das instruções foi interpretado por alguns autores como uma reprodução da divisão e hierarquização racial existente na sociedade imperial dentro da instituição militar, uma vez que parecia excluir os negros do recrutamento e, principalmente, da oficialidade do Exército. Um desses autores foi Hendrik Kraay, que fez uma vasta pesquisa sobre o tema. Segundo ele:

O recrutamento racialmente discriminatório - a preferência pelos homens brancos, a exclusão dos pretos e a admissão relutante de pardos - era um aspecto fundamental da vida dos soldados, pois eles desse modo experimentavam as hierarquias sociais e raciais do regime colonial. ${ }^{216}$

\footnotetext{
${ }^{214}$ Idem.

215 POCOCK, John. Linguagens do ideário político. São Paulo: Editora da Universidade de São Paulo, 2013 , p. 39.

${ }^{216}$ KRAAY, Hendrik. Política racial, Estado e forças armadas na época da independência: Bahia, 1790-1850. São Paulo: Hucitec, 2011, p. 131-132.
} 
Embora não se possa excluir a tentativa de hierarquização racial, talvez não se possa, igualmente, tomar essas ordens do governo de maneira radical e absoluta. $\mathrm{O}$ preto - negro liberto - não estava excluído do Exército nem da oficialidade ${ }^{217}$ por outras ordens do mesmo governo. Encontraram-se duas ordens para recrutar pretos libertos: uma de 14 de novembro de 1822, mandando-se criar um batalhão de artilharia de posição, e outra de 22 de outubro de 1825, mandando preencher os batalhões 10 e 11 de caçadores de Montevidéu. Além das ordens expressas, "pretos” também entravam para o serviço militar por meios polêmicos: o dono dava um escravo em troca de si no serviço das armas, prática que o governo oscilava entre aceitação e proibição. Indício disso é o decreto de 26 de fevereiro de 1824, que proibia as trocas de soldados por escravos libertos e que não se admitisse tal prática "sem ordem expressa" do Imperador.

Pode-se considerar assim, junto com Hebe Mattos, ${ }^{218}$ que as categorias raciais citadas - "negro", "preto" e "pardo" - não se referiam exclusivamente aos tons variados de cor da pele. Trata-se de algo mais complexo, indicando a correlação entre a cor da pele, a condição socioeconômica e o status ocupado pela pessoa na sociedade. Assim, as ordens do governo imperial de não recrutar "negros" não devem ser entendidas como a proibição do recrutamento de pessoas de fenótipo negro, mas sim de indivíduos que, para além de terem a cor de pele negra, possuem uma condição social específica, qual seja, de escravo.

Também é necessário apontar para o fato de que a forma final do artigo estabelecendo o serviço para os "cidadãos brasileiros" não excluía, decerto, os pretos do serviço. Isso porque no artigo $6^{\circ}$ da constituição de $1824^{219}$ os libertos nascidos no Brasil eram considerados cidadãos. Sua redação estava mais preocupada, então, em excluir estrangeiros do serviço, particularmente os africanos libertos. O modelo de Exército defendido, pode-se afirmar, era o composto por soldados-cidadãos.

Não obstante, essa medida, se comparada com a outra proposta, era restritiva. Tanto mais quanto sopesada à interpretação de Ferreira França sobre a cidadania e naturalização. Permitir a entrada de africanos libertos no serviço das armas poderia

\footnotetext{
${ }^{217}$ SILVA, Luiz Geraldo. Gênese das milícias de pardos e pretos na América Portuguesa: Pernambuco e Minas Gerais, séculos XVII e XVIII. Revista de História, São Paulo, ${ }^{\circ}$ 169, p. 118. Disponível em: <http://www.scielo.br/pdf/rh/n169/0034-8309-rh-169-00111.pdf>. Acesso em: 12/03/2015, às 14:00.

${ }^{218}$ MATTOS, H. A Escravidão Moderna nos Quadros do Império Português: o Antigo Regime em perspectiva atlântica. In: FRAGOSO, João Luís; BICALHO, Maria Fernanda; GOUVÊA, Maria de Fátima (Orgs.). O Antigo Regime nos Trópicos. A Dinâmica Imperial Portuguesa (séculos XVI-XVIII). Rio de Janeiro: Civilização Brasileira, 2001, v. 1, p. 141-162.

219 "[São cidadãos brasileiros] I. Os que no Brasil tiverem nascido, quer sejam ingênuos, ou libertos, ainda que o pai seja estrangeiro, uma vez que este não resida por serviço de sua Nação.”
} 
levar a uma maior integração desse grupo à sociedade envolvente, fazendo-os criar laços com o Estado a que, contra a própria vontade, faziam parte. Essa posição política pode até ser interpretada como uma maneira de manter a própria organização social inclusa a própria escravidão - ao cooptar elementos potencialmente perigosos e descontentes para o serviço do governo. ${ }^{220}$

Esses dois projetos, no entanto, não podem ser encarados como arautos da modernidade ou do passado. Ambos traziam em si elementos que podem ser encarados como novos ou antigos. O texto proposto, e que foi aprovado, por Holanda Cavalcante, ao delimitar o serviço exclusivamente a cidadãos, alinhava-se a alguns projetos europeus e ao norte-americano de recrutamento. Outrossim, tomado isoladamente, anunciava em gérmen uma distribuição igualitária do "tributo de sangue", posto que as isenções viessem a contrariá-la. Esses seriam elementos considerados "modernos" de organização militar. A exclusão, contudo, dos africanos libertos num país escravocrata reproduzia a hierarquia social existente no conjunto da sociedade, como bem apontou Hendrik Kraay.

As propostas de Coutinho, Vasconcelos e Pereira, por sua vez, ao incluir os pretos africanos forros, tinham uma perspectiva inclusiva e integracionista. Como projeto político, poderia ser considerado "avançado", porém, aceitar o serviço de homens considerados estrangeiros era típico de um exército da idade moderna, que alguns autores nomeiam como um Exército de "Antigo Regime". ${ }^{221}$

Por outro lado, é interessante notar como muitos conceitos importantes ainda eram debatidos, mesmo após as definições constitucionais. Se não debatiam quem seria cidadão tal como o fizeram na Constituinte de 1823 , debatiam o conceito de cidadão da Constituição de 1824. Ou seja, a própria Carta imperial tornou-se objeto de discussão e de interesses diversos. Talvez se pudesse afirmar que o conceito de "constituição" tornou-se um "arquilexema" a que todos os membros da elite política deveriam se referir, muito embora com concepções e entendimentos diferentes. ${ }^{222}$ Isso é perceptível pelo fato de que ambos os projetos em discussão argumentavam nas grades conceituais oferecidas pela Constituição, chegando, no entanto, a conclusões díspares.

\footnotetext{
${ }^{220}$ GRINBERG, O fiador dos brasileiros. Keila Grinberg analisa as propostas políticas feitas por Antônio Pereira Rebouças durante as legislaturas da década de 1830.

${ }^{221}$ SOUZA, Adriana Barreto de. O Exército na Consolidação do Império. Rio de Janeiro: Arquivo Nacional, 1999.

${ }^{222}$ KOSELLECK, Reinhart. História dos conceitos e História social. In: Futuro Passado. Rio de Janeiro: Contraponto, 2006, p. 107.
} 
As instruções seguiram sendo discutidas durante todo o ano de 1826 e foram aprovadas em quase sua integralidade, com alguns poucos artigos sendo suprimidos. Embora vários debates tenham sido interessantes, não cabem no escopo deste trabalho. De maneira sintética, as instruções eram consideradas um verdadeiro avanço em relação às orientações e práticas existentes porque resguardavam grupos considerados economicamente importantes ou socialmente vulneráveis e estabelecia uma rotina administrativa que, tal como disse Cunha Mattos, se fosse seguida firmemente, evitaria muitos abusos por parte dos recrutadores. Isso é indício de que tanto o governo quanto os parlamentares apresentavam preocupação quanto à salvaguarda dos direitos individuais dos cidadãos do Império. Essa preocupação será apresentada de maneira mais clara a seguir, na análise dos casos de abusos no recrutamento no Ceará e em Minas Gerais.

\subsubsection{Dão-se homens como porcos: os casos do Ceará e de Minas Gerais}

Durante o período da Guerra da Cisplatina, o governo fez amplos esforços de recrutamento, como dito anteriormente. Dentre as províncias, as que mais contribuíram com homens foram as do Nordeste e as do Sudeste. No recrutamento dos soldados, no entanto, foram cometidos vários abusos, tanto na "captura" quanto no transporte dos recrutas. Dois casos se tornaram emblemáticos dessas práticas abusivas: um no Ceará e outro em Minas Gerais. Para tornar a narrativa e a análise mais claras, os casos serão expostos em separado, embora tenham ocorrido quase simultaneamente.

Iniciemos pelo Ceará. A província do Ceará encontrava-se, por volta de 1825, com bastantes problemas. A região havia passado por grande número de secas desde o século XVIII e que perduraram durante o século XIX - 1724 a 1727, 1791 a 1793, $1809,1816,1824$ e 1825, para nos mantermos no recorte cronológico desta pesquisa. ${ }^{223}$ Além do problema climático que afetava seu desenvolvimento, a população também sofreu por sua participação na Confederação do Equador, em 1824. Afora isso, a província também padeceu com uma epidemia de "bexiga", ou melhor, de varíola, que assolou parte dos cearenses. Como expôs o presidente da província, Antônio de Sales Nunes Berfort, em fevereiro de 1826:

\footnotetext{
${ }^{223}$ POMPEU, Thomaz. Juízo histórico do senador Pompeu sobre factos do Ceará. Revista do Instituto do Ceará, ano IX, 1895, p. 5.
} 


\begin{abstract}
A cidade capital do Ceará apresenta um quadro tocante e desconsolador; as ruas estão apinhadas de um sem número de mendigos, o palácio do governo e casas dos particulares abastados constantemente cercadas desses miseráveis apresentando o espetáculo de esqueletos mirrados de fome, só cobertos de pele, representando outras tantas imagens da morte. A miséria, a pobreza e a consternação aparecem em todos os pontos da província e o número dos que tem sucumbido é incalculável. Os principais ramos de indústria, que constituem as rendas públicas e a fortuna particular, como o gado e algodão, estão quase extintos pelas perturbações de 1824 e pela longa e flagelante seca; os cofres públicos estão exaustos sem poderem pagar as tropas e os empregados; os mesmos particulares e negociantes se acham privados, aqueles de seus bens e estes dos gêneros que formavam a base de seu comércio; uns estão arruinados, outros reduzidos à pobreza (...). ${ }^{224}$
\end{abstract}

Para tornar a situação do Ceará ainda pior, o governo imperial expediu ordem, em 1825, para que se recrutassem 3.000 homens e os remetessem para o Rio de Janeiro, onde assentariam praça. O pedido foi interpretado pelos contemporâneos como um abuso por parte do ministro da Guerra, uma vez que era considerada uma província despovoada e de "segunda ordem". Conforme afirmou Lino Coutinho, em 10 de agosto de 1826:

Sr. Presidente, será a província do Ceará o viveiro dos homens? Não, de certo: pelo contrário, sabemos que ela é a mais despovoada de todas as do norte; pois de uma província despovoada, e da segunda ordem, onde muitas vezes o braço da providência se descarrega com rigor e onde há secas terríveis, que se vai tirar braços para o recrutamento ${ }^{225}$

As autoridades cearenses, no entanto, anuíram ao pedido do governo e iniciaram o recrutamento na província, sob a direção do comandante das armas Conrado Jacob de Niemeyer. Tal atribuição claramente violava o parágrafo 31 da lei de 20 de outubro de 1823, que encarregava os presidentes de província pelo recrutamento. Tão logo os recrutadores conseguiram um número grande de recrutas, o comandante das armas os enviou para a Corte sem vacinação contra varíola. Entre 1825 e março de 1826 foram embarcados 2.630 soldados. $^{226}$

Não só esse número era grande em relação ao total de habitantes da província, como, durante o transporte dos soldados, 553 deles morreram antes de chegar ao Rio de Janeiro. Entre as razões para a mortandade, estão a varíola e a superlotação das embarcações. Esse trágico evento foi denunciado logo depois de iniciada a sessão

\footnotetext{
${ }^{224}$ Apud POMPEU, Thomaz. Juízo histórico do senador Pompeu sobre factos do Ceará, p. 6-7.

${ }^{225} \mathrm{ACD}$, sessão de 10 de agosto de 1826, tomo IV, p. 101.

${ }^{226} \mathrm{O}$ presidente de província lista os navios que receberam soldados e a quantidade de homens que foram levados em cada um deles: 750 na nau d. Pedro I, 250 no bergantim d. Pedro, 150 na sumaca Gerves, 400 na corveta Carioca, 600 na galera dinamarquesa Jorge Frederico, 230 no bergantim Boa União e 250 no Imperador do Brasil.
} 
parlamentar de 1826, em que os deputados acusaram as autoridades provinciais dos abusos cometidos e pediram ao governo que fossem tomadas contra elas medidas punitivas.

Em 11 de maio, numa das primeiras sessões após a abertura dos trabalhos legislativos, o deputado José de Albuquerque, representante do Ceará, foi o primeiro a denunciar o fato na Câmara. Seu discurso foi contundente porque ele fora testemunha do ocorrido:

(...) [o governo do Ceará] fretou duas embarcações, um brigue, em que fez embarcar 232 pessoas, e uma sumaca dentro da qual meteu 150. Não sei quantos destes morreram no brigue, mas na sumaca morreram 68. Eu sou testemunha ocular porque vim nela. Embarcaram-se estes desgraçados quase nus, tendo alguns somente as ceroulas com que vieram das prisões em que tinham antes sido sepultados. Deu-se-lhes carne seca e farinha: não havia botica, nem cirurgião a bordo: morriam aos sete por dia. ${ }^{227}$

O tratamento dispensado aos recrutas nos transportes foi imediatamente comparado ao de mercadorias - "tem-se remetido a bordo como rolos de tabaco ou caixas de açúcar uns sobre outros nos porões dos navios" ${ }^{228}$ - e ao de escravos vindos da África. A conclusão dos representantes era a de que ao escravo eram dispensados maiores cuidados que aos soldados já que "ao senhor interessa em não perder o capital empregado", 229 algo que o governo do Ceará aparentava não ter para com os súditos do Império. O deputado Cunha Mattos contrastou a regulamentação existente na época para os navios negreiros e a ausência de lei para o traslado dos soldados:

\footnotetext{
As leis mandam que os escravos sejam embarcados na razão de 7 palmos por 5 toneladas, ou de 5 por 2 toneladas! Mas já se fez alguma lei de arqueação para o embarque dos soldados? Nunca: e será possível que se lancem estes homens no porão de um navio sem ser arqueado? É possível que se tratem assim cidadãos brasileiros, que se pegue neles, que se metam em porões de navios, sem roupa e sem outros arranjos necessários para a conservação do homem? É possível que assim seja degradada a espécie humana? Que assim se degrade a reputação e o decoro do Brasil? Assim se reduzem homens livres à condição a mais ínfima, ainda inferior à dos escravos? Como é possível que os cidadãos brasileiros, cidadãos soldados sejam tratados pior do que escravos? ${ }^{230}$
}

Além da mortandade e da desumanidade no transporte marítimo, a condução terrestre dos soldados também foi duramente criticada. Na mesma sessão de 11 de maio, Cunha Mattos acusou os recrutadores de tratarem os soldados como "bestas de carga", ao serem enviados com "algemas e gargalheiras ao pescoço". E pergunta: "São estes os

\footnotetext{
${ }^{227}$ ACD, sessão de 11 de maio de 1826, tomo I, p. 42.

${ }_{228}$ ACD, discurso do deputado Cunha Mattos, sessão de 10 de agosto de 1826, tomo IV, p. 100.

${ }^{229}$ ACD, discurso do deputado José de Albuquerque, sessão de 11 de maio de 1826, tomo I, p. 42.

${ }^{230} \mathrm{ACD}$, sessão de 10 de agosto de 1826 , tomo IV, p. 103.
} 
que vem servir a nação? São estes os homens que hão de apresentar ao inimigo um coração intrépido e corajoso?". ${ }^{231}$ É importante ressaltar que nesse momento as instruções analisadas anteriormente não haviam ainda se tornado lei e esse caso foi um grande estímulo para sua discussão.

Os deputados, no entanto, não ficaram somente em discursos acusatórios. Pediram, no mesmo dia, esclarecimentos ao governo sobre o ocorrido, pedido que foi reiterado em 22 do mesmo mês. Em 3 de junho, o ministro da Guerra, o então Barão de Lages, respondeu em ofício à Câmara que os eventos relatados pelos deputados muito "magoaram ao paternal coração do (...) augusto senhor [o Imperador]" e que haviam sido dadas todas as "necessárias providências para conhecer se em tais males teve parte o desleixo de alguma autoridade ou empregado". ${ }^{232}$

Como parte dessas providências, o ministro pediu em 7 de junho esclarecimentos ao presidente da província acerca do ocorrido. Ele respondeu em 8 de agosto, culpando o comandante das armas da província pelos abusos cometidos. ${ }^{233} \mathrm{Em} 7$ de maio de 1828, após as inquirições feitas pelo governo, o ministro da Guerra, Bento Barroso Pereira, mandou ofício à Câmara informando que:

(...) tendo o governo de sua Majestade recebido as informações que se haviam mandado pedir àquela província e conhecendo por elas que o comandante das armas não se acha suficientemente justificado; houve o mesmo augusto senhor por bem mandar demiti-lo do referido comando e pela repartição a meu cargo se passarão ao ministro e secretário de estado dos negócios da justiça as convenientes ordens para que, à vista dos respectivos papéis, mandasse proceder segundo for de direito. ${ }^{234}$

Quase simultaneamente às denúncias do caso cearense, apareceu o relato de práticas consideradas abusivas no recrutamento em Minas Gerais. Em 14 de junho de 1826, numa discussão sobre a isenção do serviço de milicianos agricultores, o deputado Vasconcelos pela primeira vez apontou que recebera cartas narrando o recrutamento de soldados milicianos durante a festa religiosa de Corpus Christi, que ocorrera em fins de maio. O tema, porém, somente entrou em discussão dois dias depois a pedido do deputado Cunha Mattos. Afirmou este:

Sr. Presidente, neste instante acabo de saber que na província de Minas Gerais estão praticando as maiores arbitrariedades e despotismo mais escandaloso e as mais desumanas atrocidades contra os pobres milicianos. (...) Estamos perdidos, sr. Presidente, os cidadãos brasileiros estão reduzidos

\footnotetext{
${ }^{231}$ ACD, sessão de 11 de maio de 1826, tomo I, p. 44.

${ }^{232}$ ACD, sessão de 5 de junho de 1826, tomo II, p. 34.

${ }^{233}$ Apud POMPEU, Thomaz. Juízo histórico do senador Pompeu sobre factos do Ceará, p. 12-14.

${ }^{234}$ ACD, sessão de 7 de maio de 1828, tomo I, p. 22.
} 
à última desgraça, os que são milicianos são tratados pior que escravos, acham-se reduzidos a nada, pende-lhes sobre as cabeças toda a sorte de arbitrariedades, e todas as iniquidades. (...) Os milicianos de Minas vêm por essas estradas amarrados, acorrentados e carregados de ferros... Estes milicianos foram convidados pelos seus respectivos chefes para a procissão do corpo de Deus e atraiçoadamente foram presos e acorrentados: são negociantes, fazendeiros e artistas: eles aí vêm debaixo de escolta. ${ }^{235}$

Em seguida, enviou uma indicação à mesa para ser votada, em que se pedia ao governo esclarecimentos sobre o "trágico negócio, afim de se aplicarem providências enérgicas para de uma vez se desterrarem as prepotências e arbitrariedades". ${ }^{236}$

Demonstrando profunda indignação pelo ocorrido, muitos deputados teceram duras críticas aos funcionários responsáveis. Vasconcelos, por exemplo, em uma de suas falas mais contundentes chegou a dizer que "Nós sabemos que se oferecem ao governo homens como se oferecem porcos", no que foi bastante apoiado pelos colegas no recinto. ${ }^{237}$ É importante observar que em 1826 o clima político na Câmara não era de oposição direta e intensa ao Imperador e seus ministros. As tensões aumentariam com o fim de 1826 e cada vez mais nos anos seguintes da legislatura, primeiramente em relação aos ministros e progressivamente em direção à figura do monarca.

Em face dessas práticas abusivas, a elite política parlamentar arrogou-se o papel de defensora da Constituição e de seus direitos e "liberdades" contra o que chamavam de "absolutismo" e "despotismo" das autoridades imperiais. Deixou bem clara essa posição o deputado Vergueiro: ${ }^{238}$

O governador das armas de Minas Gerais, ou quem quer que foi, atacou a
liberdade individual e pública, e menoscabou todas as garantias do cidadão: é
um ato de puro absolutismo, que se acaba de perpetrar, e ao governo pertence
fazer puni-lo com as penas da lei, e reparar os danos às vítimas de tal
atrocidade: se o não fizer compete então à Assembleia tornar efetiva a sua
responsabilidade. (...) O que agora se pretende fazer é propugnar pelas
garantias constitucionais e pela liberdade dos cidadãos. Na verdade, convidar
homens para uma procissão, cercá-los e prendê-los, para virem acorrentados
para o Rio de Janeiro é a maior traição e barbaridade que se pode cometer. ${ }^{239}$

\footnotetext{
${ }^{235}$ ACD, sessão de 16 de junho de 1826, tomo II, p. 160-161.

${ }^{236}$ Ibidem, p. 161.

${ }^{237}$ Ibidem, p. 162.

${ }^{238}$ Nascido em Valporto, Portugal, em 20 de dezembro de 1778, faleceu no Rio de Janeiro em 17 de setembro de 1859. Foi bacharel em leis pela Universidade de Coimbra. Veio para o Brasil em 1805 e como advogado estabeleceu-se em São Paulo. Representou essa província nas Cortes portuguesas em 1822, na Constituinte brasileira em 1823, e na primeira legislatura. Foi eleito senador por Minas Gerais em 1828. Ocupou a pasta do Império, interinamente a da Fazenda em 1832, e a da Justiça em 1847; foi um dos membros da regência provisória depois da abdicação de D. Pedro I. Dirigiu o curso de direito de São Paulo de 1837 a 1842. Era do Conselho do Imperador, gentil-homem honorário da imperial câmara; grã-cruz da ordem do Cruzeiro e membro do Instituto Histórico e Geográfico Brasileiro.

${ }^{239}$ ACD, sessão de 16 de junho de 1826, tomo II, p. 161. É importante realizar um esclarecimento acerca dos conceitos que o parlamentar apresenta. Ele utiliza a palavra "absolutismo" para caracterizar o ato de perseguição às liberdades individuais realizada durante o recrutamento. Isso parece ser um recurso
} 
Depois de breve arrazoado, a indicação de Cunha Mattos foi colocada em votação e aprovada. O ministro da Guerra respondeu no dia seguinte (17/06), afirmando que o recrutamento, até onde soubera, havia ocorrido dentro da lei e que não houvera abusos, mas que pediria esclarecimentos às autoridades mineiras. Estes vieram quase um mês depois, em 13 de julho. O mesmo ministro enviou à Câmara a resposta que recebera do governador das Armas da província, Antônio José Dias Coelho. ${ }^{240}$ A carta é marcada por certa ironia e arrogância, ou ao menos assim soou para os deputados, que se sentiram muito ofendidos. O comandante iniciou dizendo ter recebido com “inexplicável estranheza” o pedido de esclarecimentos vindos de S.M.I. e com "igual estranheza e suma admiração" que o motivo da solicitação viesse da Câmara dos Deputados. Em seguida, afirmou que as alegações feitas eram falsas e o que o deputado "informante" - Cunha Mattos - havia sido "iludido" por um "inventor" e então passou a se defender. ${ }^{241}$ Em sua defesa, afirmou:

\begin{abstract}
(...) não me sendo possível cumprir de pronto uma tal determinação [de mandar um batalhão de caçadores milicianos à Corte] pela repugnância, escusa e total aversão que declaradamente mostram todos os indivíduos da $2^{\text {a }}$ linha, e com particularidade os que compõem os batalhões; representei em ofício de 18 de Fevereiro (...) dirigido a V. Ex. [o ministro da Guerra], a dificuldade de fazer imediatamente uma semelhante remessa e os motivos que ocorriam para espaçar até o dia de Corpus Christi o concluir a expedição da gente requisitada, declarando no mesmo meu ofício à V. Ex. que, como tinham de se juntar e comparecer nesse dia, era ocasião oportuna, dos que então comparecessem, escolher os menos pensionados e que menos falta fizessem; e para confirmação de que procedi em regra e de que o silêncio de V. Ex. pôs o cunho à minha deliberação, concluía assim o meu ofício - e para que se possa concluir esta diligência da maneira que levo dito, julgo necessário não se publicar nos Diários o aviso, que por V. Ex. me foi expedido. - Decorrendo pois, quase três meses desde 18 de Fevereiro a 25 de Maio, era de supor estar aprovado meu arbítrio, mui principalmente não ignorando V. Ex. que, a não ser assim, nenhum outro meio havia para mandar tropas da $2^{a}$ Linha. (...) Assoalhar que de S. João saíram carregados de ferros é uma soleníssima impostura (...) somente desta cidade [Ouro Preto] saíram cinco acorrentados, três que eram desertores dessa corte e dois soldados (...) por serem revoltosos e perturbadores (...). Concluo (...) que os fatos que causaram tanto desgosto e exaltação nos corações compadecidos dos
\end{abstract}

retórico para atacar o sistema político anterior à existência das monarquias constitucionais, ao mesmo tempo que exalta, por contraste, estas últimas, entendidas como garantidoras da liberdade por meio da ação da Assembleia. Em outros discursos analisados, o termo "absolutismo" também foi associado a "despotismo" e "tirania", conceitos que antes da Revolução Francesa eram distintos e que após esse movimento tornaram-se intercambiáveis no vocabulário dos chamados "liberais" ou "constitucionalistas". FURET, François. Antigo Regime. In: FURET, François; OZOUF, Mona. Dicionário Crítico da Revolução Francesa. Rio de Janeiro: Ed. Nova Fronteira, 1989, p. 621-632. KIRSCHNER, Tereza Cristina. A reflexão conceitual na prática historiográfica. Textos de História, v. 15, n. 1 /2 (2007), p. 53.

${ }^{240}$ Não se obtiveram muitas informações sobre o comandante. O deputado Cunha Mattos atesta-o como um tenente-general conhecido por suas pias práticas religiosas e com idade avançada. Cf. ACD, sessão de 26 de julho de 1826, tomo III, p. 311-320.

${ }^{241}$ ACD, sessão de 13 de julho de 1826, tomo III, p. 158. 
augustos deputados eram absolutamente falsos, que as ordenanças militares estabelecidas como necessárias à disciplina e recrutamento do Exército sempre se continuaram no seu primitivo vigor, como expressamente o declara a constituição tit[úlo] 8 , art. $179, \S 10$ e que por consequência, não tendo divergido, nem abusado da autoridade que Sua Majestade havia depositado em minhas mãos, fica sem nota, antes plenamente ilibado o meu comportamento (...). ${ }^{242}$

A resposta de Coelho é interessante porque, em nenhuma parte de sua carta, ele tenta negar o ocorrido. Ao contrário, reafirma-o, diz ter tido a anuência - ainda que silenciosa - do governo na Corte e, para além disso, estar baseado na Constituição imperial, no mesmo artigo que defendia os direitos individuais dos cidadãos do Império. As razões pelas quais tomou esse "arbítrio" são simples: era muito difícil recrutar os soldados depois que eram emitidos os avisos - era comum a fuga dos recrutáveis após expedida a convocação - e a data do feriado favoreceria a prática, já que todos os homens estariam reunidos nas cidades durante a celebração. Quanto ao uso de ferros, tão criticado na Câmara, teria sido usado em três desertores - criminosos, pela lei - e em dois soldados "revoltosos e perturbadores".

A questão que se põe então é: como o comandante se viu respaldado pela Constituição, nesse caso? No dispositivo legal mencionado pelo militar, a Carta imperial afirma que nenhum homem poderia ser preso sem ordem escrita da "autoridade legítima", exceto em caso de flagrante delito. Em seguida, afirma: "O que fica disposto acerca da prisão antes de culpa formada, não compreende as Ordenanças Militares, estabelecidas como necessárias à disciplina, e recrutamento do Exército". Ou seja, para recrutar, os comandantes poderiam prender os homens em flagrante sem determinação judicial, escolher os que se encaixavam no perfil de homem recrutável e, então, liberar os demais.

A resposta foi aceita na Casa legislativa e enviada para comissão mista de Guerra e Constituição para que se realizasse um parecer. Este, apresentado em 18 de julho, criticou duramente o comandante. A comissão iniciou o parecer afirmando "estranhar e estranhar muito o descomedido estilo em que o referido comandante militar se atreveu a escrever em seu ofício" e chegou a duas conclusões: em primeiro lugar, que o comandante agira de má fé na prática de recrutar os homens durante a cerimônia religiosa. Em segundo, que era réu-confesso uma vez que admitiu ter prendido homens a ferros - o que havia sido proibido pelo decreto de 23 de maio de 1821 , mesmo os

\footnotetext{
${ }^{242}$ Ibidem, p. 158-159.
} 
criminosos - sem culpa formada, ato considerado ilegal pela Constituição. Achavam-se, assim, "violadas as garantias individuais dos cidadãos". ${ }^{243}$

A discussão do parecer começou no dia 26 de julho e foi marcada por longos discursos e acusações. Os principais temas debatidos foram o estilo da carta e seu desrespeito aos representantes e à Câmara, e a corresponsabilidade ou não do ministro pelos abusos contra os milicianos.

O tom do debate sobre o estilo da carta foi grave. Todos os deputados que se pronunciaram foram implacáveis contra o general. Alguns chegaram mesmo a considerar que a maneira como escrevera significava que tinha o apoio do ministro. Exemplo disso é o discurso do deputado Lino Coutinho:

\begin{abstract}
Como, senhores, um comandante militar a não estar de costas bem quentes, se animaria a dar semelhante resposta em um ofício, sabendo que há de subir à augusta presença do Imperador e desta Câmara dos deputados? Como se atreveria a dizer que com grande estranheza viu o ofício que se lhe havia remetido sobre os atrozes atentados que ele mesmo havia perpetrado contra a santidade de todas as leis? Pois o súdito tem linguagem de estranheza para com seus superiores? Não conhece as regras da subordinação ou ao menos as da civilidade? Não para aqui senhores; neste ofício não só se empregam os termos da maior ousadia e atrevimento, mais ainda se passa a mais: nele chama-se o ridículo sobre a câmara, lança-se mão das ironias mais picantes e faz-se aplicação dos sarcasmos os mais ferinos para injuriar os representantes da nação. Só porque cumprem o seu dever, só porque desempenham as obrigações para que foram chamados de suas casas. ${ }^{244}$
\end{abstract}

O sentimento de que o ministro da Guerra o apoiava ficou mais forte porque, no dia 13 de julho - no dia em que a resposta do comandante havia sido entregue na Câmara -, o mesmo ministro publicara um pequeno texto no Diário Fluminense elogiando a conduta do general. ${ }^{245}$ Isso levou a especulações sobre se a acusação deveria recair somente no general ou se também era necessário e cabível acusar o ministro. Enquanto alguns deputados, como Cunha Mattos, julgavam culpado somente o comandante, outros, como Vasconcelos, Souza França, Lino Coutinho, Vergueiro e Custódio Dias também propuseram a acusação do ministro. Conforme se pronunciou este último:

\footnotetext{
${ }^{243}$ ACD, sessão de 18 de julho de 1826, tomo III, p. 222.

${ }^{244}$ Ibidem, p. 314-315.

245 Disse o ministro da Guerra: "Sendo presente a Sua Majestade o Imperador o ofício de Vossa Excelência de 30 de junho próximo passado, dando conta da maneira por que marchara para esta Corte o contingente de Tropa de $2^{\mathrm{a}}$ Linha, e reconhecendo-se por ele não ter sido acompanhado de medidas de violência com que fora caracterizado; foi agradável ao Mesmo Augusto Senhor o não ver estremecido o bom conceito em que sempre teve a Vossa Excelência, pela inteligência, honra e zelo com que o há servido e assim lho manda significar para seu devido conhecimento". Diário Fluminense, 13 de julho de 1826, p. 54. Disponível em: <http://bndigital.bn.br/hemeroteca-digital/>. Acesso em: 18/02/2015, às 16:00.
} 
... direi que nele [no ofício] está o corpo de delito do general e que se as leis valem alguma coisa deve ser exemplarmente punido. (...) Estes verdugos dos brasileiros, parece, que querem pôr a toda a prova a nossa paciência ou a nossa indiferença. Pois é possível que ousem vangloriar-se dos seus próprios crimes e das traições com que vão levando esta infeliz nação às bordas do precipício! Eu não quero que a culpa recaia somente sobre o moribundo general: é escravo e déspota e há de acabar escravo e déspota (...). A indignação dos povos pelas injustiças e iniquidades com que são tratados, tem-se manifestado de um a outro canto do império. A guerra de extermínio está declarada a todos os cidadãos, principalmente àqueles que amam a Deus e à lei... (rumor no salão) Este ministro da guerra e todos os outros estão fazendo ataques diretos, guerra aberta ao sistema... ${ }^{246}$

Embora os ânimos tenham se inflamado contra o ministro, nenhuma acusação formal foi aprovada pela Câmara, uma vez que ainda não havia sido aprovada a lei de responsabilidade dos ministros, discutida na Casa entre 1826 e 1827, e que adormeceu no Senado até 1828. De acordo com Vantuil Pereira, os casos do Ceará e de Minas Gerais deram impulso para que essa lei fosse aprovada pelos deputados. ${ }^{247}$

Depois de finalizado o debate, o parecer foi posto sob votação e aprovado, tendo sido enviado como forma de resolução da Câmara ao ministro Barão de Lages, no dia 27 de julho. Pedia-se, em seu último parágrafo, a responsabilização do comandante das armas. A pesquisa não encontrou, contudo, qualquer medida tomada contra o mesmo, como ocorreu no caso cearense.

Esses casos são interessantes para análise dos direitos dos cidadãos brasileiros por vários motivos. Temos as denúncias de dois abusos na Câmara, o pedido de investigação e responsabilização dos comandantes, a punição de um deles, a comparação entre o status de soldado e o de escravo, a defesa enfática dos direitos individuais dos súditos do Império.

A demissão como forma de punição ao comandante das armas do Ceará, embora possa parecer pequena em face da tragédia cometida, é indício de que o governo imperial se preocupava em manter a legalidade e sustentar os direitos dos brasileiros. $\mathrm{O}$ fato de que foi por pressão parlamentar que adveio a punição não retira mérito do governo, mas o reforça, já que era o papel institucional atribuído à Câmara dos Deputados, qual seja, o de fiscalizar as ações dos ministérios. ${ }^{248}$

\footnotetext{
${ }^{246}$ ACD, sessão de 26 de julho de 1826, tomo III, p. 317.

${ }^{247}$ PEREIRA, Vantuil. Ao Soberano Congresso. Universidade Federal Fluminense: tese de doutorado, 2008 , p. 150.

${ }^{248}$ No artigo 37 da Constituição, lê-se: "Também principiarão na Câmara dos Deputados: I. O Exame da administração passada, e reforma dos abusos nela introduzidos". Outrossim, a Carta imperial dá à Câmara o papel de denunciar os ministros conforme a lei.
} 
A relação entre o serviço das armas e o de escravos, por sua vez, é bastante difundida no Brasil imperial. ${ }^{249}$ Temos, em primeiro lugar, um recrutamento que, na prática e contra as determinações legais, utilizava grilhões e ferros para evitar a fuga dos homens. Eles eram forçados a assentarem praça e passar muitos anos servindo ao Estado. Em segundo lugar, os salários eram baixos, como visto, e muitos ex-escravos conseguiam ganhar mais por dia trabalhado. Isso foi abordado por Lino Coutinho em 1830: "Qual é o homem livre que vai ter trabalhos tão peníveis pelo vil prêmio de 160 rs.? Poder-se-á com isto sustentar mulher e filhos? Qualquer preto cargueiro faz hoje no ganho 480 e 640 rs. por dia". ${ }^{250}$ Em terceiro, várias punições aos soldados eram similares às empregadas aos escravos, o que será abordado no capítulo seguinte. A ênfase dos deputados em combater os abusos no recrutamento, criticar os baixos salários e as punições são, levanta-se como hipótese, ideias aventadas para se criar um Exército de cidadãos.

$\mathrm{Na}$ discussão desses eventos, entre as acusações e os discursos exasperados, todos os parlamentares que se expressaram não deixaram de argumentar em favor da legalidade e da defesa dos direitos dos cidadãos. Em suas análises, a ojeriza da população ao serviço militar provinha de sua desconfiança em relação ao governo, que por vezes não liberava os soldados no fim do serviço, atrasava frequentemente o soldo, usava de meios escusos e ilegais para recrutar - como no caso de Minas Gerais -, ou tratava os recrutas pior que escravos - como no caso cearense. É perceptível em suas falas a ideia de que há um contrato entre cidadão e governo epitomizado na Constituição e que se estende a todo o aparato legal do Estado, em que ambas as partes deviam obrigações. Nesse caso, o soldado deve colocar-se a serviço do governo e este deve utilizar dos expedientes legais para convocá-lo. ${ }^{251}$ Para eles o problema se iniciava quando o governo ignorava as leis, tornando a população receosa de lidar com o Estado. Forçoso é admitir que a posição adotada pela maioria dos representantes era marcada por interesses políticos imediatos, isto é, de se opor ao gabinete de Pedro I, mas que não retira a força dos argumentos empregados.

\footnotetext{
${ }^{249}$ MCBETH, The politicians versus the generals, p. 60.

${ }^{250}$ ACD, sessão de 28 de julho de 1830, tomo II, p. 249.

${ }^{251}$ Isso fica claro na fala de Vergueiro: "Pois qual há de ser o miliciano que obedeça sendo chamado para o serviço quando vê o tratamento que o espera e está firmemente convencido de que o governo o atraiçoa e que ainda não cumpriu uma só vez as promessas e as condições com que o convida? Os súditos estão obrigados para com o governo e o governo não estará obrigado para com o súdito?”. ACD, sessão de 26 de julho de 1826, tomo III, p. 317.
} 
Algumas conclusões podem ser esboçadas após essa abordagem do Exército e do Recrutamento no Brasil Imperial. A primeira, mais geral, refere-se à discrepância entre as determinações legais estabelecidas para evitar abusos e a prática da rotina administrativa. A segunda, a posição legalista radical da Câmara na defesa dos direitos dos cidadãos. A terceira, a defesa de um Exército de soldados-cidadãos.

No que se refere à incongruência entre o que foi determinado pelo governo e a efetiva prática dos comandantes, podem ser elencadas três conclusões distintas por parte do pesquisador: (1) o governo quer parecer constitucional por "cinismo" para evitar críticas e não envida esforços para reprimir um sistema que ele verdadeiramente aprova; (2) o governo não tem condições administrativas efetivas para "impor" suas vontades aos rincões do país e então se submete às práticas das potestades locais; ou (3) o governo tenta regular seus agentes, mas, por variados motivos, seu direcionamento não é completo nem totalmente eficaz.

A primeira conclusão foi desmentida pela pesquisa. Sob a pressão de grupos no Parlamento e de denúncias de abusos no recrutamento por parte de comandantes no Ceará e em Minas Gerais, o governo tomou providências e puniu os responsáveis. Para além disso, seria praticamente impossível acessar um tal "cinismo" e, mesmo, explicar os eventos por essa perspectiva.

A segunda conclusão foi tomada por Fábio Faria Mendes em seus trabalhos sobre o recrutamento no Brasil imperial. ${ }^{252}$ Para ele, o governo não possuía capacidades administrativas - leia-se, de organização e coerção - para realizar, ele mesmo, o recrutamento, servindo-se dos senhores locais para tanto. Dessa forma, suas intervenções diretas nas práticas do recrutamento eram muito pouco efetivas.

A terceira conclusão é a que parece explicar melhor os eventos pesquisados. Embora não se tenha estudado especificamente o relacionamento do governo com as elites locais, a maneira como o governo respondeu aos questionamentos e pressões do Parlamento parecem indicar um esforço da administração central em tomar o controle do processo do recrutamento. Isso não significa dizer que o Estado era capaz de ditar

\footnotetext{
${ }^{252}$ MENDES, Fábio Faria. Recrutamento militar e construção do Estado no Brasil imperial. Belo Horizonte: Argvmentvm, 2010.

MENDES, Fábio Faria. Encargos, privilégios e direitos: o recrutamento militar no Brasil nos séculos XVIII e XIX. In: CASTRO, Celso; IZECKSOHN, Vitor; KRAAY, Hendrik (Orgs). Nova História Militar Brasileira. Rio de Janeiro: Editora FGV, 2004.
} 
unilateralmente as medidas a serem tomadas, mas que, a partir de constantes negociações com essas elites, conseguia lançar as diretrizes gerais a serem seguidas e foi capaz de punir seus funcionários quando os abusos se tornavam muito grandes e evidentes. Fernando Uricoechea mostrou bem esse complexo entrelaçamento entre governo central e elites locais na burocracia imperial. ${ }^{253}$

Pôde-se constatar, igualmente, uma forte e intensa defesa, por parte dos deputados, pelo resguardo aos direitos dos cidadãos brasileiros. Tal preocupação foi possível de se observar nos discursos transcritos ao longo do capítulo. Certo é que essa defesa não estava livre de posicionamentos políticos conjunturais, mas, de qualquer maneira, indica a existência de um movimento legalista geral na Câmara. Para esses parlamentares, é possível afirmar, o cumprimento da lei era o único escudo contra abusos por parte do Executivo. Isso explica, em parte, sua indignação e temor quando funcionários e ministros descumpriram as determinações legais, e, além disso, elucida seu impulso em votar leis de responsabilidade dos empregados públicos e dos ministros.

Por fim, parece claro a esta pesquisa a vontade de parte da elite política imperial, particularmente dos deputados advindos da casta militar, em modificar o entendimento sobre o serviço das armas. Isso foi constatado na denúncia aos abusos durante os recrutamentos no Ceará e em Minas Gerais, na crítica ao modelo que tornava o soldado quase em um escravo, na proibição do governo do uso de escravos como soldados e na crítica ao uso de mercenários feita em 1828, prática efetivamente abolida em 1830. Se ao cidadão cabia a tarefa de sustentar a "Independência e integridade do Império", ao Estado pertencia o dever de resguardar-lhes seus direitos no serviço das armas.

${ }^{253}$ URICOECHEA, Fernando. O minotauro imperial. Rio de Janeiro: Difel, 1978. 


\section{Os castigos no Exército}

As práticas de punição dentro do Exército passaram, tal como o recrutamento analisado no capítulo anterior, por discussões e debates bastante prolíficos no Primeiro Reinado, e pela mesma razão: a adequação desses mecanismos ao mundo constitucional que despontava no Império. Esse processo encontra-se referenciado num quadro maior de reorganização do sistema criminal e processual penal, iniciado na década de 1820 e finalizado na década seguinte com o Código Criminal e o Código de Processo Penal. Nesse grande contexto, as discussões giravam em torno dos limites de ação do Estado na execução da justiça, os limites da punição e o que se buscava no momento de punir. Quais seriam os castigos aceitáveis para os cidadãos? A punição deveria ser exemplo para os demais da sociedade, deveria levar o desviante a refletir sobre sua conduta ou simplesmente retirar um elemento perigoso do convívio social? De outro modo, quais punições corporais eram aceitas e quais passaram a ser condenadas como "bárbaras"? Até onde era permitido ao Estado ir sem que ferisse as garantias individuais dos cidadãos?

Muitas foram as respostas e os projetos apresentados sobre o tema. No entanto, o que perpassava a todos era a preocupação em "humanizar", "civilizar" e trazer as "Luzes" para a legislação penal brasileira, ainda que as definições do que era considerado "humano" e, em contrapartida, "cruel", variassem entre as diversas ideias e projetos apresentados. Mesmo os dispositivos constitucionais, que à primeira vista poderiam parecer muito claros e objetivos, foram objetos de disputa parlamentar durante a primeira legislatura, de modo semelhante ao que foi abordado nos capítulos precedentes.

Posto isso, o objetivo deste capítulo é analisar os debates e as leis acerca dos castigos dentro do Exército durante o Primeiro Reinado. Não é o intento analisar aqui os procedimentos de justiça e a rotina jurídica para a execução da pena. 
Para alcançar tal propósito, serão primeiramente expostas e analisadas as punições previstas nos regulamentos militares do Conde de Lippe - e que estavam vigentes no país durante o período estudado - para, então, passarmos ao estudo das mudanças constitucionais, das medidas tomadas pelo Executivo e dos projetos parlamentares sobre o tema.

\subsection{Os regulamentos do Conde de Lippe}

Os regulamentos militares do Conde de Schaumbourg-Lippe foram feitos no século XVIII para Portugal no contexto da guerra dos Sete Anos e no bojo das reformas realizadas no Estado luso pelo Marquês de Pombal. Esse aparato normativo foi herdado pelo Império brasileiro após a independência e forneceu as diretrizes organizacionais das forças armadas brasileiras durante longo período.

$\mathrm{O}$ "Regulamento para o exercício e disciplina dos regimentos de Infantaria dos Exércitos de Sua Majestade Fidelíssima", ${ }^{254}$ escrito pelo nobre alemão, que concerne mais propriamente a esta pesquisa, é dividido em 27 capítulos, tratando detalhadamente dos aspectos mais importantes do serviço de infantaria, desde o "estado e formatura das companhias", passando pelos "castigos" até os "Artigos de Guerra"255, sendo esses dois últimos os mais importantes para a análise proposta.

As forças terrestres lusas eram despreparadas e indisciplinadas quando o marechal alemão assumiu seu comando. Para ele, o Exército do reino ibérico poderia se reformar e se tornar uma força moderna somente mediante punições exemplares, com disciplina e ordem estritas - que seriam obtidas pela exata observância de seus regulamentos. ${ }^{256}$ Estes, contudo, foram considerados por vários contemporâneos como muito duros e com punições muito pesadas para delitos e crimes por vezes considerados comuns no Exército português.

Essa ideia de inculcar a disciplina por meio de punições é clara nas seções dos castigos e artigos de guerra referidos. Diz ele na primeira seção do regulamento para a infantaria:

\footnotetext{
${ }^{254}$ LIPPE, Conde de. Regulamento para o exercício e disciplina dos regimentos de Infantaria dos Exércitos de Sua Majestade Fidelíssima. Secretaria de Estado: Lisboa, 1763.

${ }^{255}$ Capítulos I, XI e XXVI da obra, respectivamente.

${ }^{256}$ RODRIGUES, Neuma Brilhante. Nos caminhos do Império: a trajetória de Raimundo José da Cunha Mattos. Tese de Doutorado: Universidade de Brasília, 2008, p. 14.
} 
Os delitos maiores e sobretudo o motim, o homicídio premeditado e a traição hão de ter pena de morte. O réu passará pelas armas, será enforcado ou padecerá morte mais severa nos casos extraordinariamente atrozes, conforme julgar o Conselho de Guerra, em consequência dos Artigos Militares. Os delitos graves, que não forem contudo capitais, se castigarão mandando-se trabalhar os réus nas fortificações por meses ou por anos, conforme a gravidade do delito. Estes criminosos trabalharão com grilhão no pé e na mão direita e um rótulo nas costas que declare seu delito. (...) enquanto durar o tempo das suas condenações, se conservarão em estreita prisão e não receberão de pão e paga mais que o precisamente necessário para sustentar a vida. (...) as culpas leves cometidas por descuido ou inadvertência serão castigadas com vinte, trinta ou cinquenta pancadas, dadas com a espada de prancha ou metido o réu em prisão a pão e água; ou fazendo-lhe montar guarda sem lhe competir; ou carregando-o de armas, uma ou muitas horas, os quais castigos leves se darão sem Conselho de Guerra. ${ }^{257}$

Já seus Artigos de Guerra - que deveriam ser lidos aos soldados todas as vezes em que fossem receber os salários - previam ainda mais punições. Dos 24 artigos, em 13 estava estabelecida a pena capital, e em alguns repetem-se os crimes graves listados acima. São eles:

I. Aquele que recusar por palavras ou discursos obedecer às ordens dos seus superiores, concernente ao serviço, será condenado a trabalhar nas fortificações; porém se se lhe opuser, servindo-se de qualquer arma ou ameaça, será arcabuzado. (...) III. Todo o oficial de qualquer graduação que seja, ou oficial inferior, que sendo atacado pelo inimigo desampara o seu posto sem ordem será punido de morte. IV. Todo o militar que cometer uma fraqueza escondendo-se ou fugindo quando for preciso combater será punido de morte. V. Todo o militar que em um batalhão, ação ou combate ou em outra ocasião de guerra der um grito de espanto, como dizendo - "O inimigo nos tem cercado; Nós fomos cercados; Quem puder escapar-se, escape-se" ou qualquer palavra semelhante que possa intimidar as tropas, no mesmo instante o matará o primeiro oficial mais próximo que ouvir. VI. Todos são obrigados a respeitar as sentinelas ou outras guardas; aquele que o não fizer será castigado rigorosamente; e aquele que atacar qualquer sentinela será arcabuzado. VIII. Todas as diferenças e disputas são proibidas sob pena de rigorosa prisão; mas se suceder a qualquer soldado ferir o seu camarada à traição ou o matar, será condenado ao carrinho perpetuamente ou castigado com a pena de morte (...). XII. Se algum soldado se deixar dormir ou se embebedar estado de sentinela ou deixar o seu posto antes de ser rendido (...) se for em tempo de guerra, será arcabuzado. XIV. Todo aquele que desertar ou que entrar em conspiração de deserção; ou que sendo informado dela a não delatar; se for em tempo de guerra, será enforcado: e aquele que deixar a sua companhia ou Regimento, sem licença, para ir ao lugar do seu nascimento ou a outra qualquer parte que seja, será castigado com pena de morte, como se desertasse para fora do reino; e sendo em tempo de paz, será condenado por seis anos a trabalhar nas fortificações. XV. Todo aquele que for cabeça de motim ou de traição, ou tiver parte ou concorrer para estes delitos ou souber que se urdem e não delatar a tempo os agressores, será infalivelmente enforcado. XVI. Todo aquele que falar mal de seu superior nos Corpos de Guarda (...) se na indagação que se fizer se conhecer que aquela murmuração não fora procedida somente de uma soltura de língua, mas encaminhada a rebelião, será punido de morte, como cabeça de motim. XVII. Todo o soldado se deve contentar com a paga, com o quartel e com o uniforme que se lhe der; e se se opuser, não o querendo receber, tal qual se

${ }^{257}$ LIPPE, Regulamento..., p. 156-157. 
lhe der será tido e castigado como amotinador. XIX. Todo o soldado que não tiver cuidado nas suas armas, no seu uniforme e em tudo o que lhe pertence; que o lançar fora, que o romper, ou arruinar de propósito e sem necessidade; e que o vender, empenhar ou jogar; será pela primeira e segunda vezes preso; porém à terceira, punido de morte. ${ }^{258}$

Em outros 4 artigos estavam previstas penas corporais, como, por exemplo, o artigo XI: "Aquele que faltar a entrar de guarda ou que for à parada tão bêbado que a não possa montar, será castigado no dia sucessivo com cinquenta pancadas de espada de prancha". 259

O uso de castigos no Exército, no entanto, engendrou-se na lógica de aplicação da justiça no Antigo Regime português. De acordo com António Manuel Hespanha, a função do direito penal real de Portugal entre os séculos XVI e XVIII não parece ser a "disciplina social", mas antes a de afirmar o "sumo poder do rei como dispensador, tanto da justiça como da graça". ${ }^{260}$ Para afirmar esse duplo papel, a justiça régia deveria se fazer temer por meio da "ameaça" da pena, ao mesmo tempo em que se fazia "amar", ao não se cumprir a ameaça de punição. ${ }^{261}$ Como afirma o autor:

Assim, e ao contrário do que muitas vezes se pensa, a punição no sistema penal efectivamente praticado pela justiça real no Antigo Regime - pelo menos até o advento do despotismo iluminado - não era nem muito efectiva, nem sequer muito aparente ou teatral. (...) Ou seja, mais do que em fonte de uma justiça efectiva, o rei constitui-se em dispensador de uma justiça apenas - e, acrescente-se, cada vez mais - virtual. (...) o rigor das leis (...) fora sendo temperado por estilos de punir cada vez mais brandos. ${ }^{262}$

A outra face da justiça real era o perdão e a dispensa da graça perdoando os crimes de seus súditos, como sinais visíveis da clemência, misericórdia e magnanimidade do monarca. Era esperada a intervenção régia para reduzir os castigos ou livrar os criminosos de suas penas. Em suma:

Pelos expedientes de graça realizava-se outro aspecto de inculcação ideológica da ordem real. Se, ao ameaçar punir (mas punindo, efectivamente, muito pouco), o rei se afirmava como justiceiro, dando realização a um tópico ideológico essencial no sistema medieval e moderno de legitimação do poder, ao perdoar, ele cumpria um outro traço da sua imagem - desta vez como pastor e como pai -, essencial também à legitimação. A mesma mão que ameaçava com castigos impiedosos, prodigalizava, chegado o momento, as medidas de graça. Por esta dialéctica do terror e da clemência, o rei

\footnotetext{
${ }^{258}$ Ibidem, p 228-235.

${ }^{259}$ Ibidem, p. 231. Os outros artigos que preveem penas corporais são: X, XXI e XXV.

${ }^{260}$ HESPANHA, António Manuel. Da “iusticia" à "disciplina”. Textos, poder e política penal no Antigo Regime. In: HESPANHA, António Manuel (Org.). Justiça e litigiosidade: história e prospectiva. Lisboa: FCG, 1993, p. 500-501.

${ }^{261}$ Ibidem, p. 518.

${ }^{262}$ Ibidem, p. 521.
} 
constituía-se, ao mesmo tempo, em senhor da Justiça e mediador da Graça. Se investia no temor, não investia menos no amor. $^{263^{3}}$

Embora o Marquês de Pombal, durante o período em que foi o ministro mais importante do reino, tenha realizado uma série de reformas para tornar os processos administrativos e jurídicos mais efetivos do ponto de vista estatal, esses traços da justiça régia acima descritos não desapareceram de uma vez. Ao contrário, foi uma longa sucessão de avanços e retrocessos que encontraria maior expressão no movimento liberal da década de 1820 .

$\mathrm{Na}$ área militar, as características da justiça régia iam de encontro aos planos disciplinares de Lippe, e por vezes ele criticou a clemência e o perdão reais. ${ }^{264}$ Para seu plano funcionar, seria necessária a imediata e plena aplicação dos castigos previstos. Caso o monarca interviesse e diminuísse ou perdoasse a pena, os soldados e oficiais não interiorizariam a obediência e a disciplina necessárias para o modelo de exército proposto, já que sempre a graça e o perdão trariam esperança de livramento aos desviantes da norma.

Essa realidade institucional militar e jurídica também se aplicava à América portuguesa. Um general próximo a Lippe, Johann Böhm, foi enviado para o Rio de Janeiro na década de 1760 para colocar em prática os regulamentos do príncipe alemão. Aqui chegando, enfrentou várias dificuldades e problemas com as autoridades coloniais, que eram bastante reticentes em reconhecer sua autoridade e, mais, em impor a disciplina que o general esperava. Finalizado seu tempo em terras brasileiras, não havia obtido muito sucesso em reorganizar as tropas americanas. ${ }^{265}$

Os regulamentos de Lippe continuaram válidos em solo brasileiro após a independência do Império. Esses códigos, porém, que já vinham sendo criticados em Portugal desde sua promulgação, ${ }^{266}$ passaram a ser ainda mais questionados em sua estrutura disciplinar, devido à ênfase do movimento constitucionalista brasileiro aos direitos individuais dos cidadãos e, depois de 1824, à abolição formal de açoites e penas cruéis. A partir de 1826, em decorrência da intensificação das atividades militares na fronteira Sul do país, vários problemas militares surgiram, como referido em capítulos

\footnotetext{
${ }^{263}$ Ibidem, p. 525.

${ }^{264}$ COSTA, Fernando Dores. Insubmissão. Lisboa: Universidade Nova de Lisboa, tese de doutorado, 2005 , p. 249.

265 SOUZA, Adriana Barreto de. Duque de Caxias. Rio de Janeiro: Civilização Brasileira, 2008, p. 4795.

266 _. A governança da justiça militar entre Lisboa e o Rio de Janeiro (1750-1820). Almanack. Guarulhos, n. 10, agosto de 2015, p. 401.
} 
anteriores. Esses desafios, particularmente a deserção, renderam respostas e reflexões diferentes por parte do Executivo e do Legislativo. Como se verá, o Executivo utilizouse do expediente do castigo e do perdão imperial. A Câmara dos Deputados, por sua vez, fez uma análise interessante das causas da indisciplina nas tropas e propôs outras saídas, algumas das quais ligadas ao regime anteriormente existente e outras mais próximas ao espectro "liberal" e "moderno", indicando a riqueza das experiências e projetos de futuro presentes na Casa.

De modo a tornar a apresentação mais clara e objetiva, serão narrados os problemas enfrentados pelo governo imperial no período entre 1822 e 1828, assim como as medidas tomadas para resolvê-los, a fim de, em seguida, passar-se às reflexões feitas pela Câmara sobre as mesmas questões.

\subsection{Entre as chibatas, os açoites e a Constituição}

\subsubsection{O Executivo, os castigos sumários e os perdões}

Desde 1822 até 1828, no contínuo esforço bélico pela independência, pela supressão da Confederação do Equador e contra as Províncias Unidas do Rio da Prata, o Império do Brasil teve de lidar com os diversos problemas do recrutamento e do seu reverso, a deserção. O Exército brasileiro sofria constantes baixas decorrentes da fuga de seus combatentes, o que, por sua vez, gerava mais rodadas de recrutamento, normalmente feitos à força, como ficou explanado no capítulo anterior. Contudo, à medida que o Estado não conseguia suprir as tropas de maneira adequada - baixos salários, atrasos na emissão de gêneros e de pagamento - e, além disso, não conseguia obter êxitos militares, particularmente na Guerra da Cisplatina, o fenômeno da deserção tornou-se cada vez mais agudo. Dessa forma, pode-se afirmar, tal como o fez Fernando Dores Costa para o caso português, que as forças terrestres imperiais "desfaziam-se constantemente". ${ }^{267}$

Diante desse quadro, os vários ministros da Guerra de d. Pedro I tiveram de tomar algumas atitudes enérgicas. A deserção, como ficou claro a partir da transcrição do regulamento do Conde de Lippe, era um crime gravíssimo e deveria ser punido com

\footnotetext{
${ }^{267}$ COSTA, Fernando Dores. Insubmissão. Dissertação de doutoramento: Universidade Nova de Lisboa, 2006, p. 145.
} 
a morte. No entanto, em face do grande número de homens desertores, fazê-lo significaria destruir a reserva de homens que poderiam vir a servir e acabar com a mãode-obra do país. Para se ter noção da gravidade do problema, traz-se o exemplo da situação do Exército do Sul em 1827. Essa força terrestre tinha por volta de 10.000 homens no teatro de guerra. Depois da renhida batalha do Passo do Rosário entre forças brasileiras e platinas, em que o Império saiu em desvantagem, os soldados começaram a desertar em massa das fileiras. O então comandante em chefe das forças, Marquês de Barbacena, fez uma vívida descrição da situação. Advogava graves punições aos desertores e àqueles que lhes davam "couto". No entanto, não apoiava a pena de morte para este caso. Afirmou ele:

\begin{abstract}
Este mal [o da deserção] não poderá curar-se sem o vesicatório do sequestro de bens dos que desertam e nos que dão couto. A Constituição não quer sequestro, e declarando que todos têm obrigação de defender e servir à pátria, esqueceu-se de declarar que direitos perdem aqueles que o não fizerem. Uma lei a semelhante respeito é indispensável, porque a pena de morte não pode ser aplicada a mais de 4000 indivíduos, que a tantos pelo menos monta os desertores nesta província. ${ }^{268}$
\end{abstract}

Se o governo pretendesse aplicar à risca a punição de morte, o Exército do Sul perderia em torno de $40 \%$ de sua força total. Tal execução não só poderia ser considerada inumana como teria consequências nefastas. Como então o governo poderia lidar com essa situação?

A saída encontrada pelo governo de Pedro I nas situações em que a deserção se tornou mais grave foi de duplo caráter: por um lado, concedendo o perdão para aqueles que retornassem às fileiras durante um prazo estipulado; por outro, punindo sumariamente os desertores com penas corporais sem que passassem pelo Conselho de Guerra, como estava previsto para esse tipo de crime.

Entre 1822 e 1829, foram emitidos 7 perdões a desertores: 1 para soldados da brigada da Marinha em $1822,{ }^{269} 2$ perdões gerais em 1824 - ambos em junho ${ }^{270}$-, 1 perdão específico em maio de 1825 às praças das guarnições das províncias do Rio Grande de São Pedro do Sul e da Cisplatina, ${ }^{271}$ outro para os militares do Exército do

\footnotetext{
${ }^{268}$ RIHGB, 1886, tomo XLIX, $1^{\circ}$ volume. História da Campanha do Sul em 1827. Documentos anexos, p. 530.

${ }^{269}$ BRASIL. Coleção de leis do Império. Rio de janeiro: Tipografia Nacional. Ano de 1822, tomo II, p. 86.

${ }^{270} \mathrm{Um}(5 / 6 / 1824)$ trata dos desertores que ainda se encontravam foragidos e o outro (15/6/1824) daqueles que se encontravam cumprindo sentença. BRASIL. Coleção de leis do Império, ano de 1824, tomo II, p. $37 ; 39$.

${ }^{271}$ BRASIL. Coleção de leis do Império, ano de 1825, tomo I, p. 56.
} 
Sul em novembro de 1826 (que foi estendido em dezembro por dois meses), ${ }^{272}$ outros 2 gerais em $1829 .^{273}$

Em contrapartida, foram expedidas 4 ordens de punição física sumária a desertores ou suspeitos de induzir à fuga: em 4 junho de 1823; em 28 maio de 1824 mandando que fossem dadas 50 chibatadas aos réus de primeira deserção e 100 aos de segunda; outra ordem em outubro do mesmo ano mandando dobrar as penas anteriormente estabelecidas e, finalmente, uma em 3 setembro de 1825.

É importante perceber como os perdões e as punições estiveram entremeadas durante os anos de 1822 e 1825, num movimento claro de punição-perdão, de mostrar a mão firme do Monarca na hora de castigar e a graça no tempo de absolver. No entanto, nos momentos mais graves para o Exército durante a guerra, somente o perdão foi utilizado. Isso nos indica a dificuldade de o governo fazer punir e dispensar a justiça nas fímbrias do Império e em face de resistências generalizadas. Nas palavras de Fábio Mendes, as anistias e perdões eram um "mal inevitável” para as autoridades, na medida em que a execução das penas era impraticável por trazer mais malefícios que benefícios ao país. Em outras palavras, o perdão trazia um equilíbrio entre a necessidade de recrutar, de punir e reintegrar as fileiras do Exército. ${ }^{274}$

Também é interessante notar a linguagem utilizada pelo governo nesses documentos. Nos perdões, o registro documental ressalta a justiça régia conjugada com a benevolência do coração paterno do Imperador. Como ficou expresso numa comutação de pena emitida em 18 de fevereiro de 1823:

Querendo usar do direito imprescritível do poder majestático de agraciar,
perdoar ou comutar as penas impostas aos réus sentenciados na forma das
atuais leis do Império; e conhecendo quanto agradável se torna começar por
atos de beneficência do mesmo poder, que a Providência e unânime
aclamação dos povos depositaram nas minhas mãos; hei por bem comutar a
pena (...). ${ }^{275}$

Também como no decreto de maio de 1825: "Hei por bem, por Efeitos de Minha Inata Piedade (...) perdoar o crime de deserção às praças". ${ }^{276}$ Ou ainda no de 1826 : "Querendo usar de minha alta clemência a favor dos indivíduos que compõem o

\footnotetext{
272 BRASIL. Coleção de leis do Império, ano de 1826, tomo II, p. 70 e 76.

${ }^{273}$ BRASIL. Coleção de leis do Império, ano de 1829, tomo II, p. 23 e 307.

${ }^{274}$ MENDES, Fábio Faria. Encargos, privilégios e direitos: o recrutamento militar no Brasil nos séculos XVIII e XIX. In: CASTRO, Celso; IZECKSOHN, Vitor; KRAAY, Hendrik (Orgs). Nova História Militar Brasileira. Rio de Janeiro: Editora FGV, 2004, p. 124.

${ }^{275}$ BRASIL. Coleção de leis do Império, ano de 1823, tomo II, p. 31.

${ }^{276}$ BRASIL. Coleção de leis do Império, ano de 1825, tomo I, p. 54.
} 
Exército do Sul (...) hei por bem (...) perdoar o crime de deserção". ${ }^{277}$ Os exemplos são muitos e variados. É necessário demarcar, contudo, que a dispensa do perdão régio estava prevista na Constituição de 1824. No artigo 101, inciso VIII, ficou definido que o Imperador utiliza o Poder Moderador "Perdoando e moderando as penas impostas e os réus condenados por sentença”. Que a prática do perdão e anistia estejam embebidos na linguagem e mesmo na lógica de governança do Antigo Regime, isso não a torna, entretanto, anômala a essa nova engenharia política constitucional. As antigas práticas e experiências somavam-se às novas formas e padrões de maneira singular no nascente Império, formando uma síntese particular à realidade brasileira ao mesclar aspectos da tradição e da modernidade. ${ }^{278}$

A outra face da justiça imperial se fez aparente nas punições. Conforme os documentos analisados, o objetivo dos castigos sumários de chibatadas era duplo: dispensar a justiça rapidamente e, com isso, evitar a perda de disciplina; assim como liberar os indivíduos para o serviço ativo novamente. Conforme ficou expresso no decreto de 3 de setembro de 1825 :

Notando-se que com a demora do imediato castigo ao crime a que dá lugar a
multiplicidade de processos se relaxa a disciplina militar, tornando-se por
isso a pena imposta aos desertores de $1^{\mathrm{a}}$ e $2^{\mathrm{a}}$ deserção simples muitas vezes
desproporcionada à culpa, e que por conservarem-se os réus desaproveitados
mais tempo do que a urgência atual do serviço exige, sofrem os inocentes
pelo peso indevidamente dobrado de serviço que têm de fazer, e convindo
ocorrer a tais inconvenientes com medidas por agora provisórios que sirvam
mais pronta e eficazmente a desanimar a continuação das deserções; Manda
S. M. o Imperador (...) que os desertores qualificados de $1^{\mathrm{a}}$ e $2^{\mathrm{a}}$ deserção
simples, em lugar de serem julgados em conselho de guerra, sejam logo
castigados, os de $1^{\mathrm{a}}$ deserção com 60 chibatadas e os de $2^{\mathrm{a}}$ com 100
chibatadas (....).

É interessante notar nesses casos como tal forma de execução sumária sem julgamento é entendida como dupla justiça, tanto porque resolvia os casos pendentes de maneira rápida, como retirava os encargos daqueles sobrecarregados de serviço devido à ausência dos colegas. Mesmo a punição eventual de algum inocente não parece retirar o aspecto justo do processo. Esse método de aplicação dos castigos, ao dispensar a chance de defesa e considerar a priori que todos estavam culpados, negligencia as garantias individuais dos cidadãos do Império. Contudo, resta a dúvida se tal prática veio somente

\footnotetext{
${ }^{277}$ BRASIL. Coleção de leis do Império, ano de 1826, tomo II, p. 70.

${ }^{278}$ NORONHA, Fabrícia Rúbia Guimarães de Souza. Tradição e modernidade: o perdão na cultura jurídica luso-brasileira. In: SIMPÓSIO NACIONAL DE HISTÓRIA, 23, 2005, Londrina. Anais do XXIII Simpósio Nacional de História - História: guerra e paz. Londrina: ANPUH, 2005.

${ }^{279}$ BRASIL. Coleção de leis do Império, ano de 1825, tomo II, p. 128-129.
} 
devido às situações emergenciais vividas pelo Estado naquele momento ou se era uma rotina sistemática. Para confirmar qualquer das hipóteses, seria necessária uma pesquisa mais aprofundada.

Para além das execuções de chibatadas devido às deserções, o governo de Pedro I utilizou o mesmo expediente em outras práticas desviantes. Em 6 de janeiro de 1822, o então príncipe regente mandava castigar os "escravos capoeiras" presos em flagrante com 100 açoites, castigo que foi dobrado em 9 de outubro de $1824 ;^{280}$ em 22 julho do mesmo ano, ordenava que os soldados encontrados fora dos quarteis depois do horário de recolher deveriam receber 50 chibatadas; e em 3 de novembro de 1825, determinava que os soldados encontrados em "desordens e desavenças com outros" praças deveriam ser punidos com 150 chibatadas. $^{281}$

Essas punições, no entanto, geraram reclamações quanto à aplicação das penas. Em virtude disso, em 27 de fevereiro de 1823, o governo ordenou que houvesse sempre presente um cirurgião quando fossem ser dadas as chibatadas:

Tendo-se tornado improcedente, por falta de prova, a queixa que Engracia Maria, viúva de um soldado de artilharia montada, fez subir à presença de $\mathrm{S}$. M. o Imperador sobre o motivo da morte de seu marido, que ela dizia ser um castigo mandado aplicar pelo Major Lapa do mesmo corpo; pois que nas exatas averiguações a que se procedeu foram concordes as testemunhas em declarar que o soldado morrera de antiga moléstia que padecia: e querendo S. M. Imperial a restrita e saudável aplicação do castigo à culpa, mas de maneira tal que nem se ofenda a lei na diminuição, nem a humanidade no aumento: Manda pela Secretaria de Estado dos Negócios da Guerra que o General (...) ordene aos Chefes dos Corpos para ficar em regra que todas as vezes que um soldado for castigado com chibatadas seja sempre presente o cirurgião-mor do Corpo para informar do estado de saúde do réu, ficando responsáveis pelos resultados ou o cirurgião-mor se não informar com exação ou o chefe se mandar aplicar o castigo contra o parecer do mesmo facultativo. $^{282}$

Mesmo com essas precauções, tais práticas trouxeram problemas para os ministérios de Pedro I, particularmente depois de aberta a sessão legislativa em 1826. Isso porque a Constituição imperial havia abolido, em seu artigo 179, inciso XIX, "os açoites, a tortura, a marca de ferro quente e todas as demais penas crueis". Pesquisando no Diccionario da lingua portuguesa de Rafael Bluteau acrescido por Antonio Moraes Silva ${ }^{283}$ de 1813 , descobriu-se que as palavras "chibata" e "açoite" são sinônimas. No

\footnotetext{
${ }^{280}$ BRASIL. Coleção de leis do Império, ano de 1822, tomo III, p. 3. BRASIL. Coleção de leis do Império, ano de 1824, tomo III, p. 153.

${ }^{281}$ BRASIL. Coleção de leis do Império, ano de 1825, tomo II, p. 174.

${ }^{282}$ BRASIL. Coleção de leis do Império, ano de 1823, tomo III, p. 21.

283 SILVA, Antonio Moraes. Diccionario da língua portugueza composto pelo padre Rafael Bluteau, e acrescentado ANTONIO DE MORAES SILVA. Lisboa: Typographia Lacerdina, 1813. Disponível em:
} 
verbete da primeira, lê-se "Vara de cipó, ou outra delgada, que os cabos militares trazem para castigar os soldados", enquanto que em "chibatada" consta: "açoite, golpe com chibata". Se se considerar como, de fato, palavras sinônimas, o governo estava atuando flagrantemente contra a constituição que ele mesmo havia outorgado. Como se verá, no entanto, havia mais de um entendimento para essas palavras, ao menos dentro do campo de experiência de alguns deputados que discutiram sobre o tema, o que tornou o objeto mais complexo.

Em contraste a essa maneira de lidar com os problemas da distribuição da justiça e da punição adotadas pelo governo - que, como se viu, adotava uma postura de penaperdão típica do Antigo Regime em um novo ambiente constitucional -, a Câmara dos Deputados seguiu em outra direção, privilegiando o debate sobre a eficiência das penas, a constitucionalidade das chibatadas e o objetivo dos castigos militares.

\subsubsection{A Câmara debate os castigos}

As discussões parlamentares acerca das punições dentro do Exército ganharam importância em 1827 e continuaram durante o ano seguinte. As questões principais enfrentadas pelos deputados referiam-se a castigos ao crime de deserção e ao uso de chibatas e de outras penas físicas como instrumentos punitivos constitucionalmente válidos.

O tópico das punições à deserção entrou em pauta a partir de um ofício do ministro da Guerra enviado à Câmara em 17 de julho de $1827 .{ }^{284}$ Neste, o ministro pedia providências, em nome do governador das armas do Maranhão, sobre as penas a serem aplicadas aos desertores acusados de $5^{\text {a }}$ deserção.

A resposta da Câmara veio na forma de um relatório da comissão de guerra apresentado em 30 de julho. Neste, os deputados afirmaram:

A comissão é de parecer que achando-se marcadas na ordenança de 9 de abril
de 1805 as penas correspondentes ao crime de terceira deserção e na carta
régia de 1807 as que se aplicam aos réus de quarta deserção: devem os que
cometerem o crime de quinta deserção ficar compreendidos na geral
disposição do artigo 14 de guerra (...) pelo modo que se acha marcado no cap.

$<$ http://www.brasiliana.usp.br/bbd/search?filtertype $=* \&$ filter=Diccionario+da+lingua + portugueza + comp osto+pelo+padre+D.+Rafael+Bluteau $\% 2 \mathrm{C}+$ reformado $\% 2 \mathrm{C}+\mathrm{e}+$ accrescentado+por+Antonio+de+Moraes+ Silva+natural+do+Rio+de+Janeiro\&submit_search-filter-controls_add=Buscar $>$. Acesso em: 09/05/2014, às 15:00.

${ }^{284}$ ACD, sessão de 19 de julho de 1827, tomo III, p. 203. 
11 do regulamento de infantaria; e que assim se declara ao governo, por não ser necessária a explicação de lei. ${ }^{285}$

Os dispositivos legais citados - a ordenança de 1805 e a carta régia de 1807 explicavam e detalhavam, dentre outros assuntos, as penas a serem aplicadas aos desertores inveterados. O primeiro determinava que a terceira deserção deveria ser punida com o degredo para a Índia. Já o segundo comutava a pena para trabalhos forçados - o que retomava em certos aspectos o artigo XIV de guerra.

O relatório foi posto em discussão nos dias 11 e 13 de agosto e foi votado no dia 27 do mesmo mês. Destacou-se então um embate técnico entre dois oficiais superiores e conhecedores das leis militares: Cunha Mattos e Queiroz Carreira. Nos primeiros debates foram esboçadas algumas opiniões sobre a punição cabível à deserção e aos crimes militares em geral.

Para Cunha Mattos, que era um dos membros da comissão que assinou o parecer, não havia castigo suficiente que corrigisse um soldado que tivesse desertado pela segunda vez, tanto pior pela quinta. Em sua opinião, o degredo determinado pela ordenança de 1805 era a punição ideal. Sendo expulso do país depois de sua terceira deserção, o desertor não voltaria ao serviço das armas e, portanto, não haveria quarta ou quinta fugas. O problema ressurgiu com a carta régia de 1807 , já que esta estabelecia que o desertor, mesmo após sua terceira tentativa de abandonar as fileiras, deveria retornar às bandeiras. Por tais razões, ela defendia que os desertores, nos casos de quarta ou quinta deserções, deveriam ser punidos com os trabalhos nas fortificações, utilizando grilhões no pé e na mão direita e com um rótulo nas costas informando seu crime. Como disse em 13 de agosto:

A carta régia [de 1807] comuta a pena de degredo para a Índia em trabalhos de fortificação e promete novo alistamento ao réu de $3^{\text {a }}$ deserção. Em virtude da carta régia pôde existir $4^{a}$ deserção, mas para esta não há leis que arbitrem penas e por isso é que eu disse que a semelhantes agressores deve ser aplicada a pena do $14^{\circ}$ artigo de guerra dos novos regulamentos. Porque se eu tivesse autoridade, procederia por outro modo a respeito do soldado que houvesse cometido $3^{\mathrm{a}}$ deserção: eu diria a este soldado "meu amigo, vai para tua casa, Deus te ajude, não serves para isto". ${ }^{286}$

Esse posicionamento foi questionado por Queiroz Carreira nos dias de discussão. O deputado se opunha ao parecer por entender que a pena a ferros e correntes, tanto quanto o rótulo nas costas, haviam sido abolidos pela Constituição. Conforme se pronunciou:

\footnotetext{
${ }^{285}$ ACD, sessão de 30 de julho de 1827 , tomo III, p. 315.

${ }^{286}$ ACD, sessão de 13 de agosto de 1827, tomo IV, p. 124.
} 


\begin{abstract}
Acaso estarão os militares fora da constituição? Acaso se há de ainda consentir que um réu, porque teve a infelicidade de desertar, ainda além de todos os trabalhos forçados, ande com uma corrente grossa a qual é pelo dito artigo, presa do pé a mão direita, e ainda em cima um rótulo nas costas em que se declara o seu crime: lei de ferro! Lei pior que a mesma morte! A morte não será tão repugnante ao homem como a injúria e aflição de um rótulo nas costas! Essas penas infamantes estão abolidas pela constituição, e esta era de tal repugnância que já por si tinha caído e já se não executava mesmo antes da constituição $(\ldots)$. $^{287}$
\end{abstract}

Diante da acusação de ter trabalhado contrariamente à Constituição, Cunha Mattos revidou o argumento de Queiroz Carreira, iniciando, pela primeira vez, até onde se pôde constatar, o debate sobre as penas cruéis:

A minha opinião é que os desertores de $4^{\mathrm{a}}$ vez e ainda os de $5^{\mathrm{a}}$ se se tolerar o abuso de os haver, sejam punidos com a pena do cap. 14 dos novos regulamentos, porque mais valera não tolerar no exército réus de $3^{a}$ deserção. O nobre deputado clama contra os castigos fortes e diz: que os ferros estão proibidos pela constituição! Sr. Presidente, eu não acho tal proibição na Constituição; ali só se proíbem as penas cruéis: o castigo de ferros em sentenciados de crimes atrozes nunca foi considerado cruel em nação alguma; na Inglaterra, França, Estados Unidos e em outros países, os facinorosos trabalham com ferros nos pés e nas mãos; e, França, ainda os castigos contra os desertores são mais severos do que entre nós; os simples desertores trazem bigode raspado à navalha. Penas cruéis são as da roda, mutilação, extração de olhos e outros, mas a prisão em corrente nunca foi reputada cruel. Os castigos de abstinência poderão ser reputados cruéis, porque nada há que tanto mortifique o homem do que privá-lo dos alimentos necessários à vida. ${ }^{288}$

Tem-se aqui, nessa primeira discussão, alguns pontos interessantes para o objeto de pesquisa. Observa-se mais uma vez, tal como no caso do recrutamento, a disputa interpretativa dentro da Câmara dos Deputados acerca da Constituição. A partir de uma linguagem aparentemente simples do inciso XIX do artigo 179, surgem díspares entendimentos que guiam distintos projetos políticos.

Por fim, é significativo as compreensões dadas a "pena cruel" pelos dois deputados. Queiroz Carreira parece colocar sob a expressão o conjunto de penas fisicamente pesadas e moralmente humilhantes. A ênfase que pôs na ideia de que era preferível a morte ao rótulo do crime nas costas é veemente. Poder-se-ia dizer que sinaliza que a humilhação pública, ao destruir a honra do homem - mesmo de um desertor - era pena cruel e típica de Estados não-constitucionais. Cunha Mattos, por sua vez, simplifica o entendimento de pena cruel para aqueles castigos fisicamente excruciantes e aqueles que levam à mutilação do corpo. No entanto, também é perceptível que ele considera as penas ligadas à honra como muito severas. Isso fica

\footnotetext{
${ }^{287}$ ACD, sessão de 11 de agosto de 1827 , tomo IV, p. 112.

${ }^{288} \mathrm{ACD}$, sessão de 13 de agosto de 1827 , tomo IV, p. 124.
} 
claro com sua descrição de que, na França, os desertores tinham seu bigode raspado. Ora, se se entender o uso do bigode como símbolo de virilidade e honra masculina, o Estado, ao retirá-lo, também extirpa esses atributos definidores do homem viril e adulto. ${ }^{289}$ Tem-se, portanto, que ambos reputam as penas contra a honra como pesadas, mas enquanto Cunha Mattos as aceita, Queiroz Carreira as considera cruéis.

A discussão acerca do parecer terminou com a votação de um projeto de lei proposto por Holanda Cavalcante. Nele, ficava estipulado que o soldado que desertasse pela terceira vez não seria admitido em serviço novamente (art. $1^{\circ}$ ), mas aqueles desertores que já estivessem sendo julgados pelos crimes de $4^{\mathrm{a}}$ ou $5^{\mathrm{a}}$ deserção sofreriam as penas estabelecidas para a $3^{\mathrm{a}}$ deserção $\left(\operatorname{art.} 2^{\mathrm{a}}\right) .{ }^{290} \mathrm{O}$ projeto foi aprovado em 27 de agosto de 1827, com a declaração de voto em separado de Queiroz Carreira. ${ }^{291}$

A questão dos castigos e das penas cruéis retornou ao plenário da Câmara em 1828 em decorrência dos decretos e portarias do governo mandando punir os desertores com chibatadas. Em 17 de junho foi apresentado um parecer da comissão de guerra sobre um projeto de resolução do deputado Castro e Silva. ${ }^{292}$ O projeto pedia a suspensão dos decretos de 4 de junho de 1823, 28 de maio de 1824 e 3 de setembro de 1825 e demais ordens expedidas para punição corporal com chibatadas de réus desertores. Outrossim, pedia que se colocasse em vigor as determinações da ordenança de abril de 1805 referida anteriormente.

Em sua resposta, a comissão criticou asperamente as portarias e decretos do Executivo porque, em sua opinião, não resolviam o problema e o teriam tornado pior,

\footnotetext{
${ }^{289}$ FREYRE, Gilberto. Modos de homem \& modas de mulher. Rio de Janeiro: Record, 1987.

MATOS, Maria Izilda S. de. Cabelo, barba e bigode: masculinidades, corpos e subjetividades. Locus: revista de história, Juiz de Fora, v. 17, n.02, 2011, p. 138.

MIHAELY, Gil. Um fio de diferença: masculinidade no mundo do trabalho, 1870-1910. Anos 90, Porto Alegre, v. 14, n. 25, jul. 2007, p. 17-35.

${ }^{290}$ ACD, sessão de 13 de agosto de 1827, tomo IV, p. 125.

${ }^{291}$ ACD, sessão de 27 de agosto de 1827, tomo IV, p. 249. Afirmou o deputado em seu voto: "Declaro que votei contra a resolução tomada em todas as suas partes respeito (sic) à maneira de explicar o crime de $4^{\mathrm{a}}$ e $5^{\mathrm{a}}$ deserção (sic) e muito principalmente no último artigo da resolução".

${ }^{292}$ Filho do capitão-mor José de Castro e Silva e Joanna Maria Bezerra, nasceu em Aracati, Ceará, em 25 de dezembro de 1788 e faleceu na Corte em 23 de outubro de 1846. Com dezenove anos era solicitador dos feitos e execução da fazenda na cidade de seu nascimento e depois exerceu sucessivamente os cargos de tabelião e escrivão do Crato; escrivão da câmara, inspetor do algodão na capital de sua província; oficial-maior e secretário interino do governador Manoel Ignacio de Sampaio e membro da comissão consultiva junto ao governo. Foi presidente da província do Rio Grande do Norte, deputado às Cortes portuguesas em 1821; deputado na Assembleia Geral nas quatro primeiras legislaturas, de 1826 a 1841; foi ministro da fazenda de 7 de outubro de 1834 até 16 de maio de 1837. Foi senador do Império de 1841 a 1846, membro do Instituto Histórico e Geográfico Brasileiro e da Sociedade auxiliadora da indústria nacional, além de cavaleiro das ordens da Rosa, do Cruzeiro e de Cristo.
} 
aumentando o número de deserções, diminuindo o moral das tropas além de ser reputada ilegal:

\begin{abstract}
[A comissão] acha-se obrigada a informar a esta augusta câmara que estando demonstrado que o castigo das chibatadas e açoites, rodas de pau e pancadas de espada, tanto no Exército como na armada, em vez de ser útil à conservação da disciplina da tropa e marinhagem, serve mais para estragar o físico e o moral dos homens do que de os compelir a procederem como bons cidadãos, conhecendo mais que o ministro da guerra não podia sem notório abuso de autoridade suspender por uma simples portaria a execução da ordenação de 9 de abril de 1805, a qual não obstante seus palpáveis defeitos e os resultados que teve opostos à intenção do legislador (...) não devera ser anulada por um modo tão irregular (...); e estando com efeito provado que as deserções eram menos frequentes antes do que depois da publicação da ordenação sobredita e que muito mais frequentes se tornaram depois que se expediu a portaria de 3 de setembro de 1825, chegando a relaxação de muitos soldados até ao ponto de desertarem por mero divertimento e o abuso dos chefes a decidirem sem conselho da natureza dos crimes e da qualidade ou gravidade dos castigos, o que bem prova que as providências do governo tiveram um resultado inverso dos fins que se propôs, visto ser desproporcionada a pena à grandeza do delito: pois que sendo constante que muitos comandantes de corpos, por falta de leis mais providentes, mandam punir a seu arbítrio com 100, 200 e até 800 (sic) chibatadas a quaisquer soldados por culpas cometidas contra a disciplina econômica e particular dos mesmos corpos (...) de modo nenhum se podem reputar 60 ou 100 chibatadas como suficiente castigo do crime de deserção (reputado um dos mais graves do Exército) daquele soldado relaxado, a quem por culpas muito menos se aplicam mais severos castigos, não só pelos comandantes dos corpos e das companhias, mas ainda por um sargento ou outros oficiais inferiores. Tais são os efeitos da nossa atual legislação militar! (...) nem por isso a comissão se opõe ao projeto do Sr. Castro e Silva, reservando para ocasião mais oportuna a total abolição dos castigos de chibatadas, açoites, rodas de pau e pancadas de espada, tanto no Exército como na armada; ${ }^{293}$
\end{abstract}

É relevante que esse parecer tenha sido apresentado poucos dias após a sublevação dos mercenários estrangeiros no Rio de Janeiro. Entre os dias 9 e 11 de junho, os batalhões de alemães e irlandeses sublevaram-se na capital e somente com muita dificuldade o governo imperial - com a ajuda de ingleses e franceses - conseguiu retomar a ordem. Após o ocorrido, a Câmara pediu explicações imediatas ao governo sobre as causas do motim e recebeu a resposta no dia 25 de junho, num relatório feito pelo ministro da guerra, o Conde do Rio Pardo. Segundo o ministro, a insubordinação iniciou-se após um soldado se recusar a receber 100 chibatadas do major de seu batalhão, Pedro Francisco Drago. Diante da recusa, o major aumentou a punição para 220 chibatadas, fazendo com que o $2^{\circ}$ Batalhão de Granadeiros, em apoio ao camarada, se sublevasse. Em seguida, o batalhão composto de irlandeses se juntou ao movimento.

Percebe-se, assim, que as reflexões foram realizadas a partir de problemas bastante concretos pelos quais passava o Império durante seus anos iniciais. Em meio às

${ }^{293}$ ACD, sessão de 17 de junho de 1828, tomo II, p. 143. 
discussões dessas questões objetivas, no entanto, os parlamentares se muniam de princípios gerais para propor soluções. E é assim que se vê aparecer o argumento da utilidade e da finalidade das penas em contraposição à ideia de punição exemplar. A grande quantidade de chibatadas prescrita pelos comandantes a seus subordinados não evitava novas fugas - o que parecia ser o objetivo do castigo -, mas, em vez, parecia contribuir para aumentá-las ao destruir o moral dos soldados e, como será analisado adiante, ao submeter-lhes à situação análoga a dos escravos. Ou seja, a punição era inútil e estava levando a fins contrários daqueles pensados pelos legisladores.

Também é significativo notar a preocupação pelo princípio da proporcionalidade entre o crime e sua correspondente punição. Embora o arbítrio e o abuso dos comandantes na dispensa do número de chibatadas tenham sido criticados, a quantidade estabelecida pelos decretos do governo também o foi, já que, para os deputados da comissão, sendo a deserção o pior crime dentro Exército, 60 ou 100 dessas chibatas não seriam suficientes, já que para outros desvios havia castigos piores.

Igualmente importante é observar que, não obstante a defesa da comissão pelo fim das penas corporais graves, ela não argumentou a partir da constituição e sua proibição das penas cruéis. Também é notório o fato de que o debate de todos esses aspectos jurídicos foi realizado poucos anos antes da discussão e aprovação do Código Criminal. $^{294}$

Por fim, e este aspecto é bastante significativo, os deputados estavam propondo que se formalizasse uma legislação anterior ao mundo constitucional como uma maneira de melhor resguardar as garantias individuais propostas pela constituição de 1824. Os parlamentares não associaram a lei de 1805 ao "despotismo" do "Antigo Regime", tal como fizeram com outras peças legislativas. Nesse exemplo, percebe-se então a intricada relação entre as experiências atualizadas dos legisladores e o projeto de construção de uma sociedade nova marcada pelo constitucionalismo.

Todos esses tópicos foram colocados no centro do debate na Câmara quando o parecer entrou na pauta da Casa em $1^{\circ}$ e 10 de julho de 1828 . No arrazoado que se seguiu sobre o tema não houve voz contrária à abolição das chibatadas e quando o parecer entrou em votação ${ }^{295}$ foi aprovado sem demora. Isso é indício forte de que a

\footnotetext{
${ }^{294}$ SLEMIAN, Andrea. À nação independente, um novo ordenamento jurídico: a criação dos Códigos Criminal e do Processo Penal na primeira década do Império do Brasil. In: RIBEIRO, Gladys Sabina (Org.). Brasileiros e cidadãos. São Paulo: Alameda, 2008, p. 175-206.

295 ACD, sessão de 21 de julho de 1828, tomo III, p. 156.
} 
maioria dos deputados estava empenhada em abolir as penas corporais graves da instituição militar.

Em $1^{\circ}$ de julho, foi iniciada a discussão do parecer e do projeto proposto por

Castro e Silva. O debate foi curto e Cunha Mattos o dominou, apresentando dois longos

discursos e contundentes argumentos contra as chibatadas. Em suas falas, demonstrou seu grande conhecimento histórico sobre as diversas punições existentes em Portugal em períodos anteriores e também aquelas empregadas em outros países. Sua preocupação em pensar formas específicas de castigo para os soldados brasileiros passou por uma reflexão crítica dessas diferenças histórico-regionais como também a partir das categorias mencionadas anteriormente: utilidade, finalidade $\mathrm{e}$ proporcionalidade.

Sr. Presidente, eu creio que só pessoas bárbaras e só pessoas que não tenham compaixão de ver derramado o sangue humano se poderão acomodar com ideia de chibatadas em soldados; é verdade que os alemães são levados a pau e que os soldados na Inglaterra são assim castigados, porém estas ideias são opostas aos sentimentos de outras nações. Os franceses são opostos a esse castigo das chibatadas; finalmente este castigo é oposto aos sentimentos dos americanos. Eu, Sr. Presidente, tenho sido soldado e tenho mandado dar chibatadas, não porque eu quisesse, mas porque as leis ordenavam que se castigasse e isto com pau que verga; estas chibatadas são piores que os açoites; são uns verdadeiros açoites de escravos; antes da época em que as tropas inglesas estiveram em Portugal, não havia este castigo e só ao depois é que se adoptou este método de castigar, que sempre será odioso (...). Nós temos outros castigos sem que seja o de dar pancadas nem chibatadas; por isso que o duque de Lafões conhecendo esta barbaridade passou uma ordem circular para que se não desse mais pancadas com chibatas; porém chegando os ingleses a Portugal, introduziram o castigo usado em Inglaterra, de dar açoites (...) e vão-se dando essas chibatadas por arbítrio dos comandantes dos corpos, e porque o governo assim entendeu estabelecer esta disciplina como mais abreviada, para que os soldados não estivessem nos calabouços e que deste modo estariam mais prontos para o serviço; tendo ordenado que aqueles soldados que cometessem deserção simples fossem castigados com 50 chibatadas e aqueles da $2^{\mathrm{a}}$ deserção com 100 chibatadas, o que aconteceu? (...) conheceu-se que essas deserções se aumentaram depois que se introduziu o castigo das chibatadas: porque o soldado perde a moral e o brio depois que leva as primeiras chibatadas e o que chega a levar duas vezes perde de todo a vergonha e não serve para mais nada; (...) $\mathrm{O}$ governo não podia anular aquela lei de 1805 e estabelecer o castigo das chibatadas; entre nós qualquer oficial, qualquer cabo de esquadra, quebra o corpo de um soldado com essas chibatadas; e ainda há quem diga que são indispensáveis (...); julgam aqueles que intimidados os soldados talvez deixem vazios os calabouços; está conhecido que 50 chibatadas não intimidam os soldados, é arruiná-los e perdê-los; o que devia o governo ter estabelecido entre nós eram as casas de correção e de disciplina, aonde os soldados que cometessem esses pequenos crimes fossem trabalhar e fazer exercício de manhã e de tarde: deve ser admitido o castigo do jejum de pão e água e por este modo não são castigados os soldados imoralmente e nas circunstâncias das nossas leis de recrutamento, forçosamente havemos de ter homens imorais; e não é com chibatadas, mas sim com castigos morais que se faz desenvolver o estímulo, porque o castigo em usança, vilipendiando-o aos olhos de seus camaradas, faz necessariamente perder a vergonha e o estímulo de bom soldado: 
portanto, sejam quaisquer que forem as razões que se possam produzir contra os meus argumentos, eu me oporei: não é com estes castigos que se fazem bons soldados (...) tempo virá que se não castiguem soldados por outra forma que não seja por meio da disciplina correcional: nós devemos olhar para esses soldados como cidadãos livres: chibatadas são só próprias de vis escravos e fazer perder o brio, perder a honra e até a virtude. Deus nos livre de semelhantes ideias (...). ${ }^{296}$

Depois de breves falas apresentadas por Queiroz Carreira e Souza Mello, também contra as penas físicas, Cunha Mattos voltou à ofensiva e pintou um quadro ainda mais grave dos castigos no Exército:

\begin{abstract}
Não existe lei alguma que mande castigar o soldado com certo número de chibatadas, mas há lei que manda que sejam castigados com espada de prancha os soldados incorrigíveis, e, entretanto que se abole o castigo das chibatadas, fica subsistindo outro pior que é o castigo das espadeiradas, que levavam quase todos eles à sepultura, porque eram dadas por homens maus com esse instrumento de ferro; até muitos lançavam sangue pela boca e passavam do lugar do castigo para o cemitério; (...) imitemos os americanos que não têm este castigo e sigamos o caminho do brio e da honra porque o contrário torna o soldado um biltre e um homem vil, que está desonrando as bandeiras do Exército. ${ }^{297}$
\end{abstract}

Em seguida, Paula e Souza pediu a Cunha Mattos que apresentasse um projeto com ideias para "que de modo algum se verifique os castigos das chibatadas", 298 o que levou ao adiamento da discussão, retornando somente no dia 10 de julho de 1828. Mais uma vez, o debate foi iniciado por Cunha Mattos, afirmando que o castigo das chibatadas, "em vez de trazer o militar à boa disciplina, nada mais faz que relaxar a sua moral e contribuir para que o estado perca um cidadão". ${ }^{299}$ Imediatamente depois, o deputado Ferreira França pôs-se a questionar a validade constitucional das chibatadas posto que os "açoites" estavam proibidos pelo inciso XIX do artigo 179. Asseverou ele:

\footnotetext{
Ora, eu pergunto se chibatadas são açoites ou não? Creio que são açoites ou seja chibatadas ou espadeiradas ou seja o que for. Se isto é assim, nada mais justo como esta resolução, mas será preciso que primeiro se entenda se também são açoites as pancadas dadas com espadas, eu creio que sim. (...) é preciso que quem aplicar estas penas repare o dano primeiro e dê a pena para exemplo e não para afligir, porque a pena é para educar o criminoso, para ele bem obrar, porque ninguém é autorizado a fazer aflição a outro; eu não posso matar um matador e nem o público o pode, o que pode fazer é reparar o dano quanto for possível e educar o tal homem muito criminoso para ele bem obrar, e isto é que é o justo. Portanto, eu quero que se mostre que chibatadas, espadeiradas etc. são açoites. ${ }^{300}$
}

\footnotetext{
${ }^{296}$ ACD, sessão de 1 de julho de 1828, tomo III, p. 21-22.

${ }^{297}$ Ibidem, p. 22-23.

298 Ibidem, p. 23.

${ }^{299}$ ACD, sessão de 10 de julho de 1828 , tomo III, p. 83.

${ }^{300}$ Idem.
} 
Esse pedido de esclarecimento de Ferreira França encontra eco na sinonímia apresentada entre as palavras nos dicionários, como se referiu acima. Seu entendimento procura unificar os vários castigos físicos que implicam em pancadas sob a alcunha de "açoite", de modo que todos viessem a ser abolidos por serem inconstitucionais.

Cunha Mattos, no entanto, apresentou uma tênue diferença entre ambos os castigos. Afirmou que os açoites são aplicados nas nádegas, enquanto que as chibatadas ou pancadas de espadas o são nas costas. ${ }^{301}$ Em seguida, os parlamentares criticaram ainda o castigo das sentinelas duplas e o de carregar armas, ambos considerados abusivos. Propôs então o deputado Holanda Cavalcante, no lugar penas físicas citadas, a prisão e a restrição alimentar a pão e água para os crimes militares leves. ${ }^{302}$ Finda a discussão, o projeto foi encaminhado para a comissão de redação e posteriormente colocado em votação e aprovado no dia 21 de julho.

Esse debate leva a múltiplas frentes de análise. Em seus primeiros discursos, Cunha Mattos apresenta, em termos gerais, a ideia de um novo modelo de Exército formado de "cidadãos livres" aos quais não cabem as penas típicas de "vis escravos". Essa força armada deveria se basear em sentimentos positivos de valor e brio e não no medo da punição física. A ideia de tal modo de organização do Exército, por sua vez, encontra-se no meio de amplo movimento de reforma de que tomou parte algumas forças europeias, das quais se cita as propostas de reorganização das hostes portuguesas e francesas.

Fernando Dores Costa estudou o movimento de reforma institucional no Exército português entre fins do século XVIII e inícios do século XIX. Entre as propostas feitas, encontra-se a de Henry Lloyd. Esse militar filósofo propugnava por modos de motivação para além do temor da punição. Para ele, o medo tinha seu propósito organizador nas forças bélicas e era essencial para a coesão do grupo. ${ }^{303}$ Contudo, esse sentimento apela somente à necessidade natural de conservação da própria vida, o que Lloyd chama de "sensibilidade animal", e presta-se exclusivamente a instantes de desespero. Para ações "contínuas e consequentes" dos combatentes, seria necessário apelar a um outro tipo de sensibilidade, a social, ou seja, o "desejo de satisfazer as necessidades e de promover os prazeres." ${ }^{304}$ Assim, o governo deveria

\footnotetext{
${ }^{301}$ ACD, sessão de 10 de julho de 1828 , tomo III, p. 83.

${ }^{302}$ ACD, sessão de 10 de julho de 1828 , tomo III, p. 84-85.

303 COSTA, Fernando Dores. O bom uso das paixões: caminhos militares na mudança do modo de governar. Análise Social, vol. XXXIII (149), 1998 (5º), p. 987-988.

${ }^{304}$ Ibidem, p. 988.
} 
explorar e dirigir as paixões humanas, e não tentar somente reprimi-las, seja por meio da força ou do medo.

Os efeitos dessas paixões, no entanto, variavam conforme o tipo de governo, ao imprimir "a cada nação o caráter que a distingue". 305 O quadro tipológico de governos apresentado por Lloyd é conhecido: despotismo, monarquia e república. Os soldados dos Estados despóticos seriam preferíveis a todos dos Estados livres por sua obediência cega, não fossem, no entanto, esmagados pela miséria e opressão desde a infância. As repúblicas modernas, por sua vez, fundavam-se sobre um "espírito comercial" que era contrário à "disposição bélica" e, por outro lado, suas ideias de liberdade estão sempre em oposição à obediência necessária a um bom exército. ${ }^{306}$ Já as monarquias baseavamse nas distinções honorárias, apelando às ambições e aos sentimentos morais humanos. O estímulo pela honra através do mérito seria o princípio motor que animaria os homens a se engajarem e a se destacarem na atividade militar.

Processo similar ocorria na França revolucionária. De acordo com John Lynn, o Exército francês teria passado por uma "evolução moral" desde a fundação da república até o fim do Império de Napoleão, no sentido de quais motivações foram escolhidas como as mais eficazes e apropriadas para estimular os combatentes. Por um lado, a República francesa sob o comando do Comitê de Salvação Pública estimulava seus soldados a partir de um ideal de virtude cívica, que implicava autossacrifício pelo bem do Estado e da população. Esse ideal baseava-se no modelo de serviço militar das repúblicas da Antiguidade, particularmente a romana. ${ }^{307}$

A partir do Diretório até a formação do Império sob Napoleão, o governo francês deixou de estimular esse princípio republicano e passou a encorajar a Honra e os interesses pessoais dos combatentes como motivação para o serviço. Intensificou-se, assim, a distribuição de honrarias e a promoção pelo mérito e foram criados corpos diferenciados dentro das forças armadas, como a Legião de Honra, em que somente os mais destacados membros do Exército poderiam adentrar. ${ }^{308}$ Essa reformulação no mores do Exército tem várias explicações, que não cabem no escopo deste trabalho. Basta apontar que ela foi importante para a reorganização e sucesso das tropas francesas contra seus adversários até a queda de Napoleão. E mesmo após o retorno dos Bourbons

\footnotetext{
${ }^{305}$ Ibidem, p. 994.

${ }^{306}$ Ibidem, p. 995.

${ }^{307}$ LYNN, John A. Forum: Toward an Army of Honor: the moral evolution of the French Army, 17891815. French Historical Studies, vol. 16, No. 1 (Spring, 1989), p. 154. Disponível em: <http://www.jstor.org/stable/286437?seq=1\#page_scan_tab_contents >. Acesso em: 04/03/2015, às 17:00. ${ }^{308}$ Ibidem, p. 167.
} 
ao poder em 1815, muitos de seus princípios permaneceram, depois ainda do expurgo dos quadros ligados a Napoleão. ${ }^{309}$

A crítica de muitos parlamentares aos modos de punição física pode ser encarada como uma tentativa similar de transformar o princípio motivador do serviço militar. Ora, nada mais contrário à ideia da honra como estímulo do que os castigos previstos para os combatentes no Exército. Ao punir o soldado com pesadas penas corporais, algumas das quais similares às aplicadas aos escravos, o homem perdia por completo a honra, era humilhado e tornava-se inútil ao Estado. Daí que a reforma proposta por Cunha Mattos e Castro Silva de abolir essas penas não estava fundada somente num quadro maior de reforma penal, a que se referirá a seguir, mas também numa proposta de novo modelo de força armada, qual seja, uma formada por cidadãos e não por escravos.

Além da defesa desse modelo de Exército mais "virtuoso", Cunha Mattos retoma os argumentos expostos em discursos anteriores acerca da necessidade de tornar as penas proporcionais aos crimes cometidos e da finalidade das punições, qual seja, a de emendar os homens. Os princípios elencados por Cunha Mattos refletem um conjunto de ideias apresentadas por pensadores e filósofos de fins do século XVIII e inícios do século XIX, dentre os quais podemos citar Cesare Beccaria e Jeremy Bentham.

Beccaria fez grande sucesso na Europa no último quartel do século XVIII ao criticar profundamente o sistema penal, prisional e jurídico - particularmente a tortura e a pena de morte - existentes no Velho Mundo e ao propor outros princípios de organização. Entre estes, apresentou a ideia da proporcionalidade da lei e da finalidade clara da pena, a de retirar o criminoso do conjunto da sociedade. Tal como ele expõe:

Qual é o fim político dos castigos? O terror que imprime nos corações inclinados ao crime. (...) Os castigos têm por fim único impedir o culpado de ser nocivo futuramente à sociedade e desviar seus concidadãos da senda do crime. Entre as penas e na maneira de aplica-las proporcionalmente aos delitos, é mister, pois, escolher os meios que devem causar no espírito público a impressão mais eficaz e mais durável e, ao mesmo tempo, menos cruel no corpo do culpado. (...) Para que o castigo produza o efeito que dele se deve esperar, basta que o mal que causa ultrapasse o bem que o culpado retirou do crime. (...) Toda a severidade que ultrapasse os limites se torna supérflua e, por conseguinte, tirânica. (...) A crueldade das penas produz ainda dois resultados funestos, contrários ao fim do seu estabelecimento, que é prevenir o crime. Em primeiro lugar, é muito difícil estabelecer uma justa proporção entre os delitos e as penas; porque, embora uma crueldade

309 HOLROYD, Richard. The Bourbon Army, 1815-1830. The Historical Journal, vol. 14, n. 3 (Sep., 1971), p. 529-552. Disponível em: <http://www.jstor.org/stable/2637744?seq=1\#page_scan_tab_contents>. Acesso em: 16/05/2015, às 09:00. 
industriosa tenha multiplicado as espécies de tormentos, nenhum suplício pode ultrapassar o último grau da força humana, limitada pela sensibilidade e a organização do corpo humano. Além desses limites, se surgirem crimes mais hediondos, onde se encontrarão penas bastante cruéis? Em segundo lugar, os suplícios mais horríveis podem acarretar, por vezes, a impunidade. (...) Se as leis são cruéis, ou logo o serão modificadas, ou não mais poderão vigorar e deixarão o crime impune. ${ }^{310}$

Essas considerações do pensador iluminista italiano são encontradas na longa argumentação de Cunha Mattos contra as chibatadas e demais forças de penas físicas. $\mathrm{O}$ deputado, ao afirmar que 50 chibatadas não resolvem o crime da deserção ou ainda quando critica o uso das espadadeiras - que levam os homens direto para a sepultura faz ressoar os critérios de finalidade e proporcionalidade expostos por Beccaria.

As reflexões de Beccaria, por sua vez, influenciaram bastante a prolífica obra de Jeremy Bentham. ${ }^{311}$ Esse pensador utilitarista aprofundou consideravelmente as discussões sobre o sistema penal europeu, tornando mais concretos alguns dos princípios apresentados pelo pensador italiano. ${ }^{312}$ As ideias de Bentham, no entanto, não ficaram restritas à Europa, alcançando também as elites dos trópicos como deixou claramente expresso Cunha Mattos em 1826: “Eu, sr. Presidente, também tenho lido Grócio, Puffendorf, Vattel, Bentham e outros Publicistas". 313

Para além da relevância já atestada que teve seu pensamento nas discussões sobre o sistema penal imperial, ${ }^{314}$ podemos entrever vários aspectos das considerações de Bentham nas discussões apresentadas sobre os castigos no Exército. Pode-se observar isso a partir, mais uma vez, das críticas feitas às punições físicas como também das propostas realizadas por Cunha Mattos e Holanda Cavalcante para substituí-las.

O filósofo inglês utilitarista faz, em seu livro Teoria das penas legais, uma longa reflexão do que ele chama de "penas corporais". Entre essas, aquelas que mais interessam a esta análise são as "penas simplesmente aflitivas", "penas aflitivas complexas", a simples "prisão", as penas em trabalho forçado e das penas capitais. É

\footnotetext{
${ }^{310}$ BECCARIA, Cesare. Dos delitos e das penas. São Paulo: Edipro, 2015, p. 42 e 53-55.

${ }^{311}$ MORAES, Evaristo de. Prefácio da tradução. In: BECCARIA, Cesare. Dos delitos e das penas, p. 10.

${ }^{312}$ Bentham tem isso claro quando escreve seu trabalho Teoria das penas legais. Tal como ele diz no momento em que vai discutir a medida das penas: "Estabelecei uma proporção entre os delitos e as penas: é um dos preceitos de Montesquieu, de Beccaria e de outros muitos. Excelente máxima na verdade; mas que tem mais de aparato que de instrução, uma vez que se reduz a termos gerais; trabalho estéril enquanto não soubermos em que consiste uma tal proporção, enquanto não houverem regras que nos possam encaminhar seguramente na aplicação de certa pena a respeito de qualquer delito que se pode oferecer". Em seguida, Bentham passa a enumerar regras para se estabelecer a proporção citada. BENTHAM, Jeremy. Teoria das penas legais. São Paulo: Edições Cultura, 1943, p. 28.

${ }^{313}$ ACD, sessão de 21 de julho de 1826, tomo III, p. 277.

${ }^{314}$ ARAÚJO, Carlos Eduardo Moreira de. Cárceres imperiais: a Casa de Correção do Rio de Janeiro. Seus detentos e o sistema prisional no Império, 1831-1861. Unicamp: Tese de doutorado, 2009, p. 26. NORONHA, O Império dos indesejáveis. Universidade de Brasília: Dissertação de Mestrado, 2003.
} 
importante observar que Bentham não faz uma escala valorativa dos tipos de pena. Antes, estabelece um conjunto de "qualidades" das penas e analisa cada um dos tipos de punição a partir desses parâmetros, quais sejam: "Divisibilidade", "Certeza - Igualdade" no sofrimento dos réus na pena, "Comensurabilidade", "Analogia", "Ser exemplar", "Economia", "Ser reparável", "Atalhar o poder de fazer o mal", "Tendência para o melhoramento moral", "Poder converter-se em proveito", "Simplicidade no modo de se dar a conhecer" e "Popularidade". 315

Sob a alcunha de "penas simplesmente aflitivas", Bentham coloca todas as "penas corporais que consistem principalmente na dor física imediata, para as distinguir de outras penas corporais, cujo fim é produzir consequências permanentes”, da qual cita como exemplos o castigo de polés e o de chibatadas. ${ }^{316}$

As penas aflitivas complexas, por sua vez, são aquelas "cujo efeito consiste principalmente em consequências remotas, que duram e permanecem depois do ato penal". ${ }^{317}$ Essas consequências podem ser externas ou relativas ao funcionamento dos órgãos do corpo. Como exemplo das consequências externas, o autor cita o costume russo de se raspar a barba, o que nos faz recordar a punição mencionada anteriormente de se raspar o bigode, e o uso de uma "libré" diferenciada para o criminoso, o que nos relembra o uso de rótulos nas costas criticado por Queiroz Carreira. O corolário dessas penas, continua, produzem dois efeitos "desairosos": ao mexer com o físico, torna o réu "desagradável"; em relação ao moral, tornam-no objeto de desprezo, perdendo a estima dos homens. E finaliza: "quem não vê que tudo o que tende a diminuir a benevolência dos outros a meu respeito deve encerrar em si infinitas privações?" 318

Das doze qualidades que Bentham enumera, as penas simplesmente aflitivas possuem três: a certeza do sofrimento, a divisibilidade e a exemplaridade. Tal como ele afirma:

As penas simplesmente aflitivas não sofrem objeção alguma quanto à certeza: a sensibilidade humana, sobre a qual as ditas penas fazem impressão, é um atributo universal da natureza humana (...). Estas penas são mui divisíveis, muito variáveis na sua graduação; podem-se mitigar e agravar, como quisermos; esta qualidade lhes pertence na sua maior perfeição. Mas devemos reparar que as penas aflitivas andam sempre acompanhadas de outra, que tem uma natureza diferente, em razão dos sentimentos de honra, que tem mais ou menos valia entre as nações civilizadas: falo da vergonha pública, inseparável de qualquer pena simplesmente aflitiva. (...) O

\footnotetext{
${ }^{315}$ BENTHAM. Teoria das penas legais, p. 35-41.

316 Ibidem, p. 63.

${ }^{317}$ Ibidem, p. 69.

318 Ibidem, p. 76.
} 
merecimento das penas simplesmente aflitivas está principalmente em serem exemplares: tudo o que sofre o miserável da execução, pode ser visto pelo público; e na classe de espectadores, que assistem a esta cena, entra uma grande parte daqueles para quem uma tal impressão é particularmente da maior utilidade. Aqui temos o que se oferece de mais notável a respeito destas penas: quanto às outras não encerram coisa especial (...). ${ }^{319}$

E assim finaliza com a análise das penas aflitivas complexas:

Resta examinar estas penas debaixo de outro ponto de vista essencial; falo da sua tendência para a reforma do réu. A infâmia, quando sobre ao galarim, bem longe de servir para a emenda, obriga o homem, por assim dizer, a perseverar na carreira do crime: pois que a sua reputação está perdida no conceito geral, é uma consequência bem natural que nem ache confiança nem abrigo nos seus semelhantes. Como já não tem de esperar, e pela mesma razão já não tem que temer, o seu estar não pode ser pior. Se para se manter é preciso trabalhar, e não acha facilmente quem lhe dê que fazer, pela desconfiança e desprezo geral, lança mão do único remédio, que vem a ser: ou mendigar ou meter-se a roubar. ${ }^{320}$

Assim, do ponto de vista adotado pelo próprio autor, as penas aflitivas simples e complexas prestam-se mais para dar exemplo do que para qualquer outra coisa. Ademais, a ignomínia causada pela punição ou pelas consequências dela não são reparáveis e nem tendem a reformar o criminoso. Tais aspectos ficam muito claros nas falas dos deputados brasileiros. Deixaram claro que açoitar um soldado ou colocar um rótulo em suas costas não impede que o crime seja cometido novamente e ainda diminui o moral das tropas.

Algumas punições alternativas às penas aflitivas foram propostas pelos deputados, como mostrado. Holanda Cavalcante reforçou a ideia apresentada do cárcere a jejum de pão e água. Cunha Mattos, por sua vez, propôs a prisão dos soldados em casas de correção onde deveriam trabalhar e se exercitar, estimulando o seu desenvolvimento moral. Essa noção de privar os sujeitos de liberdade como forma de punição e utilizá-los como força de trabalho estava na ordem do dia do pensamento penal europeu do período e para o qual Bentham contribuiu grandemente. Como explicou Fabrícia Noronha:

A pena de prisão com trabalho estava no bojo das mudanças ideológicas distintas na Europa. Chama-nos a atenção não só o aparecimento da prisão como prática punitiva, mas a utilização do prisioneiro por parte do Estado. (...) Já no século XIX, um novo contexto social impôs mudanças para as práticas punitivas. $\mathrm{O}$ mundo ocidental procurava ser civilizado, industrial, liberal, moderno. As velhas punições não podiam mais ser aplicadas. (...) A solução encontrada na Europa foi a implantação de sistema penitenciários, baseados na privação das liberdades individuais dos criminosos em penas

\footnotetext{
319 Ibidem, p. 67-69.

${ }^{320}$ Ibidem, p. 78.
} 
mais rigorosas, baseadas no trabalho forçado, e em casas de correção que ensinavam ofícios aos condenados, tentando torná-los úteis ao Estado. A solução encontrada pelo império brasileiro em relação aos seus próprios criminosos seguiu, de certa forma, as decisões tomadas na Europa: foi a de empregá-los em algum serviço público. (...) Assim se instalou com grande força a pena de prisão com trabalho, dentro da filosofia do sistema penitenciário. $^{321}$

Expressão maior dessa ideia na Corte foi a construção da Casa de Correção do Rio de Janeiro, obra inspirada - embora construída com adaptações - no Panóptico, também criação de Bentham. ${ }^{322}$ A estrutura proposta pelo pensador inglês havia se tornado um símbolo do desenvolvimento do direito penal europeu ao propor "a correção pelo isolamento, a individualização da pena, o controle do Estado sobre o delinquente, a vigilância e a disciplina social". 323

A prisão, em seu modelo Panóptico, e as penas ativas - trabalhos forçados - são, para Bentham, as melhores punições, pois evitam que o preso faça "mal" à sociedade ${ }^{324}$ e oferecem a ele um momento para refletir sobre o crime que cometeu. Nesse sentido, mostra-se superior às penas corporais aflitivas. Afirma ele:

As penas agudas, como os açoites, enquanto se levam, não deixam lugar à
reflexão; a dor atual absorve toda a atenção: se se pudesse misturar alguma
emoção mental com as sensações físicas, seria, mais do que outra qualquer, a
do ressentimento contra o acusador, executor ou juiz: mas logo que o
tormento acabou, o padecente está livre, faz toda a diligência por se esquecer
do castigo: e tudo o que o cerca contribui para desviar de si as reflexões
saudáveis, de que depende a sua reforma. Enfim, passou a pena e esta ideia é
acompanhada de um sentimento vivo de alegria bem pouco provável à
emenda. Mas num estado de solidão (...) sente mais do que nunca a
necessidade de chamar para seu alívio todas as ideias, que lhe apresenta a
situação em que se acha; sendo a mais natural de todas estar-se lembrando
dos acontecimentos passados (...) que o levaram ao crime, de que sofre o
castigo, crime de cujos prazeres não lhe resta mais do que a lembrança e as
funestas consequências que deixaram em seu lugar.

As penas ativas, por sua vez, foram analisadas de maneira positiva em vários sentidos: tirava-se proveito do trabalho do preso e diminuía-se o custo de sua prisão, eram sentidas igualmente por todos, eram divisíveis, dava-se exemplo e seriam as que tenderiam a reformar os presos:

Se uma reunião de malfeitores ociosos é uma escola de perversidade, um ajuntamento de mal feitores ocupados não tem o mesmo perigo - a sua atenção está empregada - andam embebidos no trabalho - a ocupação atual

\footnotetext{
${ }^{321}$ NORONHA, Fabrícia Rúbia Guimarães de Souza. O Império dos indesejáveis. Universidade de Brasília: Dissertação de Mestrado, 2003, p. 146-147.

${ }^{322}$ BENTHAM, Jeremy. O Panóptico. Belo Horizonte: Autêntica Editora, 2008.

${ }^{323}$ NORONHA, O Império dos indesejáveis, p. 153.

${ }^{324}$ BENTHAM. Teoria das penas legais, p. 87.

325 Ibidem, p. 89-90.
} 
encurta os meios de espraiarem suas ideias pelos crimes que têm cometido; não têm lugar para se arremessarem nesses projetos de futuro, que estragam imaginações ociosas; além disso, sempre andam vigiados por um guarda, que impõe um freio a conversações licenciosas e que serve de animar os que mostram boas disposições (...). Mas o fruto principal desta disciplina, é adquirirem um hábito saudável - o mais saudável, particularmente para essa classe de mal feitores que se arrojaram ao crime pela aversão que tinham ao trabalho. ${ }^{326}$

Como foi colocado anteriormente, no Brasil imperial havia a previsão legal de homens da força armada com trabalhos em fortificações a jejum de pão e água, além do castigo das galés. ${ }^{327}$ As propostas dos parlamentares objetivavam, assim, torná-las as únicas possíveis, transformando todos os cidadãos, mesmo aqueles mais desviantes do comportamento socialmente aceito em membros úteis ao Estado, ao mesmo tempo em que resguardavam aos cidadãos livres os princípios e garantias constitucionais.

Muitos estudos têm ressaltado os debates e as tomadas de decisão acerca das penas de prisão no Império a partir da segunda metade do século XIX, em particular com a construção da Casa de Correção no Rio de Janeiro, como já foi mencionado acima. No entanto, tais projetos não surgiram ex nihil. Antes, foram influenciados pelas experiências concretas que ocorreram em outros países - como o Panóptico já citado, mas também os "experimentos" prisionais de Cherry Hill em 1790 e de Auburn em 1821 nos $\mathrm{EUA}^{328}$ - e por esses embates políticos realizados já na primeira década do Brasil independente. Ao propor reformas nas penas dispensadas aos membros das forças armadas, os políticos do período lançavam argumentos que entrariam novamente em disputa na formulação dos Códigos penal e processual penal da década de 1830. Percebe-se, assim, como se entremeiam as discussões sobre o serviço das armas e o contexto político mais geral acerca da cidadania e da reorganização do Estado imperial brasileiro.

$* * *$

Algumas conclusões saltam aos olhos depois desta breve análise dos castigos aplicados aos soldados no Exército imperial: em primeiro lugar, as diferentes propostas do Executivo e da Câmara dos Deputados para lidar com os desvios e crimes militares. Em segundo, a conexão entre os pensamentos de alguns parlamentares e de filósofos

\footnotetext{
${ }^{326}$ Idem.

${ }^{327}$ MATTOS, Raimundo José da Cunha. Repertório da Legislação Militar, tomo I. Rio de Janeiro: Typographia Imparcial, 1842, p. 72.

${ }^{328}$ VASQUEZ, Eliane Leal. Ciência Penitenciária no Brasil Império: Disciplinar para construir a imagem da nação civilizada. PUC-SP: Tese de doutorado, 2013, p. 25.
} 
europeus de fins do século XVIII e princípios do XIX. Em terceiro, a defesa de um modelo de força terrestre baseado na virtude da honra e não no mero medo da punição.

No que se refere às diferenças de atuação entre Executivo e Legislativo, é importante observar como o primeiro lançou mão do binômio perdão-punição, típico dos quadros referenciais de justiça do Antigo Regime. As penas corporais empregadas pelo governo de Pedro I tinham o propósito claro de ensinar pelo exemplo, inculcando medo naqueles soldados que não haviam desertado pela pena a que eram submetidos os colegas criminosos.

A Câmara dos Deputados, em sua maioria ao menos, adotava postura diametralmente oposta. É notória a maneira como a Casa lidou com os decretos do governo em que se mandava punir com chibatadas os soldados desertores. Desde o princípio, defenderam com zelo a abolição das penas corporais, utilizando uma abundância de argumentos que iam desde sua inconstitucionalidade, passando pela inumanidade dos castigos e chegando a reflexões de caráter teórico, tais como a proporcionalidade e utilidade. Nas falas dos deputados, pôde-se entrever que as finalidades das penas não eram o exemplo, mas, antes, o afastamento de um elemento perigoso da sociedade e a reforma do réu. Penas meramente aflitivas não convinham a esse modelo.

$\mathrm{Na}$ defesa de um novo formato de punições que passassem ao largo das penas simplesmente aflitivas, os legisladores apresentaram um projeto que recolocava em vigor a ordenança de 1805. É interessante nesse caso como os parlamentares articularam as experiências de um período a que chamavam "Antigo Regime" e o momento constitucional que viviam. Nessa discussão, divisa-se como instrumentos legais anteriores ao movimento constitucionalista não eram necessariamente negativos ou incongruentes com as garantias individuais dos cidadãos, como os próprios deputados fizeram parecer em outros debates. Conclui-se, assim, que o tempo histórico do período é bastante complexo e permitiu "atualizações" das práticas e das ideias dos períodos anteriores à Constituição nos quadros do mundo constitucional.

Também é relevante perceber a correlação entre as ideias apresentadas pelos deputados e aquelas de pensadores europeus do mesmo período, como as de Cesare Beccaria e Jeremy Bentham. Ambos os intelectuais analisaram e criticaram os sistemas penais e jurídicos da Europa de seu tempo e propuseram mudanças substanciais neles a partir de princípios gerais como de finalidade, proporcionalidade e utilidade das punições. Considerações similares fizeram os deputados nas apreciações que fizeram 
das práticas adotadas pelo Executivo tanto quanto no projeto apresentado para a abolição das penas físicas no Exército.

Em meio a todas essas discussões, distingue-se a defesa de um modelo de Exército que já vinha sendo advogado na Europa, qual seja, a valorização do serviço das armas por meio do estímulo à honra e não ao medo. Para tanto, os soldados deveriam ser tratados como cidadãos livres com direitos assegurados e não como "vis escravos", de quem só se espera a obediência cega. Para se alcançar tal modelo seria necessária uma reforma estrutural das forças armadas que passasse por uma mudança nos modos de punição dessa instituição. 


\section{Considerações finais}

A escrita deste trabalho foi fruto de um esforço para compreender a readequação do Exército imperial num contexto em que o Estado brasileiro se fundava sob bases constitucionais. Para tanto, foram analisados dois aspectos centrais à instituição e que envolviam diretamente o governo e a população: o recrutamento e os castigos.

De modo a entender melhor quais eram as preocupações da elite política nesse processo, algumas questões do contexto político foram analisadas no primeiro capítulo. Em especial, discutiu-se o processo de independência, o movimento constitucionalista do Porto e suas consequências no Brasil, as discussões sobre a soberania, os trabalhos da Constituinte, a discussão sobre quem era cidadão, o impacto da Carta de 1824, os trabalhos da Câmara dos Deputados na primeira legislatura, o deslocamento do conceito de direito ocorrido no período.

Passando em revista esses e outros tópicos, foi possível perceber que o Brasil da década de 1820 inseria-se num amplo movimento que questionava as bases legais do poder monárquico absoluto na Europa e pedia reformas que deslocassem o eixo da soberania da dinastia para a "nação". No contexto analisado, este conceito compreendia o "conjunto dos cidadãos" tomados individualmente. Tal desejo foi concretizado no mundo luso-brasileiro a partir do movimento revolucionário da cidade do Porto, que, tomando controle da metrópole lusa, iniciou o processo de implantação de uma monarquia constitucional no império português.

As diferenças entre as partes constituintes do mundo luso-brasileiro, no entanto, acabaram por levar à desagregação da unidade imperial e à independência de nosso país. A elite política da ex-colônia, por sua vez, concedeu seu apoio - com bastantes negociações e idas e vindas - ao herdeiro da casa de Bragança e então príncipe regente, Pedro de Alcântara, sob a expectativa de também o Brasil se tornar uma monarquia constitucional.

Pouco meses depois da proclamação realizada pelo regente em setembro de 1822 em São Paulo e de sua coroação em 12 de outubro, eram iniciados os trabalhos da 
Assembleia Constituinte do Império do Brasil. Embora seus trabalhos não tenham terminado, os debates ocorridos nesse ambiente plenário influenciaram a escrita da Constituição de 1824 e são importantes para se compreender a cultura política da época e vários dos debates que se deram na primeira legislatura do Império.

Um dos debates de maior importância refere-se ao de quem era cidadão brasileiro e quais seriam seus direitos. O embate é significativo na medida em que mostra os diferentes projetos políticos existentes no país e as experiências atualizadas do passado colonial, assim como as expectativas de construção de uma monarquia constitucional presentes nos membros da elite política imperial.

$\mathrm{Na}$ análise feita das fontes e a partir das leituras bibliográficas realizadas, foi possível perceber duas tendências principais em jogo: uma que alargava os direitos de cidadão para os nascidos livres e para os libertos - inclusos os africanos - e outro que previa esses direitos somente aos livres e aos libertos nascidos no Brasil, excluindo assim os ex-escravos africanos. Na Constituinte venceu a primeira proposta, mas na Carta de 1824 vingou a segunda.

Essa discussão foi relevante para o entendimento do objeto de pesquisa proposto uma vez que teve implicações para o recrutamento. Na primeira legislatura, como visto, os deputados, ao debaterem as instruções de recrutamento, entraram em disputa para decidir quem poderia servir no Exército. E mais uma vez se desentenderam sobre o limite do Estado em relação aos africanos libertos: não sendo cidadãos, poderiam ser soldados? Esses estrangeiros em particular poderiam lutar pelo Império, país ao qual haviam sido trazidos pela força e não por vontade própria? Como se viu, a proposta que permitia somente o recrutamento de cidadãos venceu na Câmara dos Deputados. Isso é entendido nesta dissertação como indício de que havia uma proposta, ainda que difusa, de formar um Exército de cidadãos no nascente país. Ou seja, somente aqueles que faziam parte da "associação política" que compunha o Império do Brasil ${ }^{329}$ poderiam e deveriam lutar para sustentar sua independência. ${ }^{330}$

Pouco tempo depois de fechada a Constituinte em 1823, foi outorgada a primeira Constituição do país e a única de todo o período imperial. A Carta marcou a divisão dos poderes, a organização das instituições políticas e jurídicas do país e deixou expressos em seu último artigo todos os direitos individuais dos cidadãos do Império.

\footnotetext{
${ }^{329}$ Cf. o art. 1 da Constituição de 1824: "O Império do Brasil é a associação Política de todos os Cidadãos Brasileiros".

${ }^{330}$ Cf. o art. 145: "Todos os Brasileiros são obrigados a pegar em armas, para sustentar a Independência, e integridade do Império e defendê-lo dos seus inimigos externos ou internos".
} 
A formalização do texto constitucional, contudo, não significou o fim dos debates e das disputas acerca de alguns pontos e isso foi fundamental para a pesquisa realizada. A discussão de como interpretar quem era cidadão ou não, do que era pena cruel, se o governo poderia recrutar ou não sem autorização da Câmara, entre outros pontos explorados na dissertação, foram importantíssimos para o jogo político do período, com consequências bastante concretas para os habitantes do Império. Em outras palavras, não havia "interpretação literal" do texto constitucional, ${ }^{331}$ mas lutas dentro dos grupos que compunham a elite política imperial, dentro dos poderes de Estado e entre esses mesmos poderes para definir o que era agir constitucionalmente.

Diz-se que isso era fundamental porque a partir das altercações entre os parlamentares e o combate institucional entre Executivo e Legislativo em matéria de leis e normas foi possível perceber os diversos projetos políticos em construção nesse momento histórico.

As contendas interpretativas acerca da Constituição mostram-nos como ela era central para as instituições políticas da época. Todos em disputa no campo político se referiam a ela, mesmo com argumentos e ideias díspares - sinal de como o direito também passava por transformações naquele contexto. Desde a segunda metade do século XVIII, iniciou-se na Europa continental um processo não linear de associar o conceito de "direito" à lei positiva provinda do Estado. Isso significou a retirada da legitimidade - de certo que não rapidamente - de outras fontes de direito até então aceitas, como o costume. Igualmente, as várias jurisdições existentes dentro dos Estados - como a da Igreja, das Universidades, das corporações de ofício - também foram perdendo espaço para a jurisdição régia.

O Império nasceu quando esse movimento já se encontrava com certo avanço no Velho Mundo e foi muito tributário de seus aspectos. Certamente que a administração imperial enfrentou muitas dificuldades e resistências ${ }^{332}$ para fazer valer sua vontade e direção nos rincões do país. Independentemente disso, no entanto, desde seus primeiros anos, já estava presente a noção de que era o Estado o detentor legítimo de legislar e reconhecer costumes e, por outro lado, que essas leis deveriam ser obedecidas à risca por todos.

\footnotetext{
${ }^{331}$ Como desejava o deputado Clemente Pereira em 1826: "Eis aqui tudo quanto há a fazer, tudo o mais são inovações no sistema da Constituição e forçadas interpretações e cumpre, Sr. Presidente, nada inovar por ora na Constituição e cumpre também que se estabeleça em princípio que esta deve sempre e em todos os casos ser entendida literalmente". ACD, ano de 1826, tomo I, p. 75.

${ }^{332}$ Nesse ponto é interessante recordar como exemplo a Revolta dos Quebra Quilos já na segunda metade do século XIX.
} 
Esse aspecto da cultura política é considerável para o objeto de pesquisa. Isso porque somente na medida em que o Estado se arrogava o papel legislador e direcionador é que se pode questionar como ele pretendeu adequar suas instituições ao ambiente constitucional.

Viu-se como se deu esse processo em relação às práticas do recrutamento no segundo capítulo. Foram apresentados alguns aspectos organizacionais mais gerais do Exército e, em seguida, analisadas as instruções do recrutamento feitas pelo governo regencial em 1822, os debates sobre essas mesmas instruções realizados no ano de 1826 na Câmara dos Deputados e as críticas dos parlamentares a dois casos de abuso no recrutamento, um no Ceará e outro em Minas Gerais.

Em relação à organização da força armada terrestre, mostrou-se como ela era organizada em três partes, muito embora isso fosse motivo de debate uma vez aberta a Assembleia Geral: a primeira linha, as milícias e as ordenanças. Deu-se prioridade na pesquisa às tropas pagas e às milícias, uma vez que não se encontrou nada relevante sobre o recrutamento das ordenanças.

As últimas determinações de como se realizar o recrutamento no Império foram editadas em 1822 pelo então regente Pedro de Alcântara para a província do Rio de Janeiro. Quando se iniciaram os trabalhos legislativos em 1826, as mesmas instruções foram apresentadas na forma de um projeto de lei que as alargavam para todo o território imperial. Nos debates da Câmara, elas foram apresentadas como um remédio aos abusos cometidos por recrutadores. Tão importante quanto esse aspecto, as instruções também deixavam claro que alguns grupos da sociedade não poderiam ser recrutados. O objetivo era o de proteger setores considerados importantes para a economia, os cidadãos "úteis". A lógica reproduzida aqui era a mesma que vigorava em Portugal, como apontaram Fábio Mendes e Fernando Costa. ${ }^{333}$

É importante ressaltar que o momento em que essa lei foi colocada em votação coincide com o início das operações bélicas no Rio da Prata no contexto da Guerra da Cisplatina. Para intensificar o esforço de guerra contra as Províncias Unidas, o Brasil lançou ordens de recrutamento para várias províncias do Império.

Dentre o conjunto das províncias que contribuíram com tropas, duas se destacaram pelos problemas de recrutamento já em 1826: Ceará e Minas Gerais. O caso

\footnotetext{
${ }^{333}$ COSTA, Fernando Dores. Insubmissão. Dissertação de doutoramento: Universidade Nova de Lisboa, 2006.

MENDES, Fábio Faria. Recrutamento militar e construção do Estado no Brasil Imperial. Belo Horizonte: Argvmentvm, 2010.
} 
cearense foi apresentado na Câmara dos Deputados logo em suas primeiras sessões. As denúncias dos abusos no recrutamento realizado numa província "de segunda ordem", como caracterizaram alguns parlamentares, e do tratamento dispensado aos recrutas enviados ao Rio de Janeiro foram espantosas para os homens reunidos na Casa. Ao todo, morreram 553 homens de doenças, principalmente a varíola, e por conta da superlotação nos navios de transporte utilizados. O número toma proporções ainda maiores, numa análise ex post facto, quando o comparamos com o número de mortos na batalha mais intensa da guerra que se travava no Sul. Em Passo do Rosário, em 1827, lutaram, em média, 10.000 argentinos e 8.000 brasileiros. Os mortos brasileiros são estimados em 240, menos da metade do total de cearenses falecidos nos transportes.

$\mathrm{Na}$ discussão que se seguiu na Câmara, os deputados, alguns emocionados e outros enfurecidos, pediram explicações ao governo do que havia ocorrido, de quem havia dado a ordem para o recrutamento na região e o responsável pelo transporte mal feito dos homens ao Rio de Janeiro. O governo imperial, depois de questionar o presidente de província e o governador das armas cearense, decidiu pela demissão deste último em 1828.

O caso mineiro difere um pouco do cearense por se tratar de homens das milícias e não de recrutados para a $1^{\text {a }}$ linha. Seja como for, os problemas giravam em torno da mesma questão, qual seja, a de levar os homens para assentar praça na Corte. Durante a festa e procissão de Corpus Christi de 1826, os recrutadores prenderam homens em várias cidades mineiras e levaram muitos deles acorrentados com gargalheiras até o Rio de Janeiro. Além de não ter havido o anúncio público de que haveria o recrutamento, como era a norma, os cidadãos foram presos numa festa religiosa, o que, pode-se imaginar, atacou as sensibilidades dos envolvidos. Mais uma vez foram pedidos esclarecimentos ao governo e a resposta veio em uma carta do comandante das armas da província. Ele afirmou ter trabalhado com o aval implícito do ministro da Guerra e que sua atitude se justificava porque a tarefa de recrutar homens era muito difícil com a expedição de aviso prévio. A reação dos deputados foi de profunda indignação com o comandante e com o ministro, mas a pesquisa não encontrou qualquer punição a ambos no período estudado.

Ambos os incidentes iniciaram as tensões entre o Executivo e o Legislativo, que se intensificariam até a abdicação de Pedro I em 1831, e resultaram numa gama de discussões sobre as garantias dos cidadãos do Império, assim como sobre a semelhança entre o tratamento dado a recrutas e a escravos. 
As tensões entre Executivo e Legislativo se deram porque, na análise de alguns deputados, o ministério da Guerra não poderia ter expedido as ordens de recrutamento sem a autorização da Câmara dos Deputados, uma vez que estava na Constituição imperial que a Casa tinha prerrogativa exclusiva sobre a matéria. Ao não fazê-lo, acirrou os ânimos dos parlamentares contra o governo já no primeiro ano de funcionamento do Parlamento.

Outro ponto sensível foi a defesa dos direitos dos cidadãos contra os abusos cometidos. Os deputados não cessaram de denunciar as práticas dos comandantes e do que Custódio Dias chamou de "verdugos" dos brasileiros. Em seus pronunciamentos, afirmavam que essas práticas retiravam a confiança da população no governo, o que, por sua vez, faziam com que tivessem ojeriza ao serviço das armas. Igualmente, os abusos colocavam os cidadãos numa posição similar a de escravos, com o uso de violência no momento de recrutá-los e transportá-los. Vale a pena lembrar a comparação que Cunha Mattos faz dos soldados empilhados como "caixas de açúcar" nos porões dos navios de transporte, coisa que, de acordo com ele, sequer acontecia nos navios negreiros.

Como medida para combater esses problemas, os deputados se debruçaram sobre as instruções de 1822, já referidas acima, e na lei de responsabilidade dos empregados públicos. ${ }^{334}$ Esse projeto de lei é interessante porque propunha responsabilizar todos os funcionários que executassem ordens contrárias à constituição e às leis, incluindo também os militares. Isso gerou debates significativos porque, para muitos parlamentares, os soldados num Exército constitucional deveriam ter decoradas as leis e os dispositivos constitucionais para que não fossem utilizados como arma do governo contra a institucionalidade vigente. É dizer, que soldados se portassem como cidadãos livres e não como meros "autômatos" como disse Lino Coutinho.

Nesse sentido, pôde-se perceber, por parte dos deputados presentes, uma real preocupação em adequar o Exército a uma nova realidade constitucional, em que o soldado deve lutar pelo sistema constitucional e pelo Império e não pela dinastia ou pelo imperador, como seria de se esperar de uma força compostas de "escravos" obedientes.

Foi possível encontrar as mesmas preocupações no que se refere aos castigos aplicáveis aos soldados na análise feita no terceiro e derradeiro capítulo. Para tanto, procuraram-se as determinações legais existentes no início do século XIX, as ações

$\overline{334}$ Não confundir com a lei de responsabilidade de ministros. 
tomadas pelo Executivo depois da independência e pela Câmara dos Deputados durante a primeira legislatura acerca desse tema.

A regulamentação das punições para o Exército imperial foi herdada do período colonial. Trata-se dos regulamentos criados pelo conde de Schaumbourg-Lippe durante o contexto da guerra Fantástica ocorrida na Península Ibérica na segunda metade do século XVIII. O intento de tais códigos era reformar o Exército português por meio de uma estrita disciplina. Esta, por sua vez, seria adquirida através do medo de duros castigos. Os castigos envolviam, normalmente, penas físicas graves ou a morte, como ficou explícito na transcrição do documento feita no capítulo.

O Exército imperial organizou-se sob esses regulamentos durante longo tempo. No Primeiro Reinado, no entanto, foram colocados em xeque tanto pelo Executivo quanto pela Câmara dos Deputados, embora de maneiras mui diversas.

O Executivo, em face do massivo número de desertores que assolavam as forças armadas terrestres, usou de um expediente administrativo típico das monarquias corporativas: o castigo sumário com chibatadas e, de outro modo, o perdão dos crimes. Essas ações iam de encontro aos regulamentos de Lippe por um lado, porque não seguiam o ritual para o julgamento dos crimes, e, por outro, porque colocavam esperanças nos criminosos de que sempre poderiam contar com a benevolência real.

$\mathrm{O}$ uso do expediente da pena sumariamente aplicada foi questionado pelos deputados em 1828. Os argumentos dos parlamentares contrários às chibatadas variaram bastante. Afirmaram que o número de chibatadas era pequeno para o crime - lembrando que a deserção é o pior crime do Exército -, ou seja, que não havia proporcionalidade entre crime e pena; que o castigo não "emendava" o preso, antes tornava-o inútil, isto é, não atingia sua finalidade; e, por fim, que a chibata não era um castigo apropriado para cidadãos livres, mas uma punição típica de escravos.

A discussão desses princípios de proporcionalidade e finalidade, dentre outros, também ocorria na Europa e nos Estados Unidos, num processo de reforma geral do sistema prisional, cujo objetivo era fazer com que o cidadão preso repensasse sua conduta e se tornasse útil ao Estado e não simplesmente afligi-lo como exemplo aos demais. Esse conjunto de ideias foi apresentado no século XVIII por Cesare Beccaria e aprofundado por Jeremy Bentham. Este último, em particular, influenciou consideravelmente os debates brasileiros sobre o tema. Muitas das propostas realizadas pelos deputados para alterar os quadros de punitivos do Exército parecem ter sido inspirados por seus trabalhos, como deixou explícito o deputado Cunha Mattos. 
Por fim, e isto é muito importante, o castigo das chibatadas foi entendido pelos parlamentares como algo inapropriado para um Exército composto de cidadãos porque colocava o soldado numa posição similar a de um escravo. Em resposta, fizeram e aprovaram um projeto de lei que extinguia os castigos físicos da instituição militar. Esse posicionamento reforça a hipótese apresentada de tentativa de readequação das forças armadas terrestres às bases constitucionais da nova sociedade.

Em síntese, foi possível perceber por meio da pesquisa das normas militares e dos debates na Câmara dos Deputados um processo de repensar o recrutamento e os castigos no Exército imperial, de modo a, talvez se possa dizer, atualizá-lo aos novos tempos de um mundo constitucional que lutava para se afirmar em nosso país. 


\section{Fontes}

BLAKE, Augusto Vitorino Sacramento. Dicionário bibliográfico brasileiro. Rio de Janeiro: Tipografia Nacional, 1883. Disponível em: $<$ http://www.brasiliana.usp.br/bbd/search?fq=dc.contributor.author:\%22Blake,+August o+Victorino+Alves+Sacramento,+1827-1903\%22>.

BRASIL. Anais da Câmara dos Deputados. Disponível em: $\langle$ http://imagem.camara.gov.br/pesquisa_diario_basica.asp>.

BRASIL. Constituição Política do Império do Brasil. Disponível em: <http://www.planalto.gov.br/ccivil_03/constituicao/Constituicao24.htm

BRASIL. A Constituinte de 1823. Brasília: Senado Federal, 1973.

BRASIL. Diário da Assembleia Geral, Constituinte e Legislativa do Império do Brasil. Brasília: Senado Federal, 2003.

BRASIL. Diário Fluminense, 13 de Julho de 1826. Disponível em: $<$ http://bndigital.bn.br/hemeroteca-digital/>.

BRASIL. Relatório do Ministério da Guerra. Transcrito nos Anais da Câmara dos Deputados, sessão de 19 de junho de 1830.

LIPPE, Conde de. Regulamento para o exercício e disciplina dos regimentos de Infantaria dos Exércitos de Sua Majestade Fidelíssima. Secretaria de Estado: Lisboa, 1763.

Revista do Instituto Histórico e Geográfico Brasileiro, 1886, tomo XLIX, $1^{\circ}$ volume. História da Campanha do Sul em 1827. Documentos anexos, p. 459-554.

SILVA, Antonio Moraes. Diccionario da língua portugueza composto pelo padre Rafael Bluteau, e acrescentado ANTONIO DE MORAES SILVA. Lisboa: TypographiaLacerdina, $1813 . \quad$ Disponível em: $<$ http://www.brasiliana.usp.br/bbd/search?filtertype $=* \&$ filter $=$ Diccionario + da + lingua + p ortugueza+composto+pelo+padre+D.+Rafael+Bluteau $\% 2 \mathrm{C}+$ reformado $\% 2 \mathrm{C}+\mathrm{e}+$ accresc entado+por+Antonio+de+Moraes+Silva+natural+do+Rio+de+Janeiro\&submit_searchfilter-controls_add=Buscar>. 


\section{Bibliografia}

\section{Artigos}

CARVALHO, José Murilo de. Cidadania: tipos e percursos. Estudos Históricos, vol. 9, $\mathrm{n}^{\circ} 18,1996$, p. 337-359.

COSTA, Fernando Dores. O bom uso das paixões: caminhos militares na mudança do modo de governar. Análise Social, vol. XXXIII (149), 1998 (5º).

FERREIRA, Bernardo. O essencial e o acidental: Bodin (e Hobbes) e a invenção do conceito moderno de constituição. Lua Nova (Impresso), p. 381-426, 2013.

HOLROYD, Richard. The Bourbon Army, 1815-1830. The Historical Journal, vol. 14, n. 3 (Sep., 1971), p. 529-552.

KOSELLECK, Reinhart. Linguistic change and the history of events. The Journal of Modern History, vol. 61, n. 4 (Dez., 1989), p. 649-666.

LYNN, John A. Forum: Toward an Army of Honor: the moral evolution of the French Army, 1789-1815. French Historical Studies, vol. 16, No. 1 (Spring, 1989), p. 154. Disponível em: 〈http://www.jstor.org/stable/286437?seq=1\#page_scan_tab_contents>. MENDES, Fábio Faria. A economia moral do recrutamento militar no Império do brasileiro. Revista Brasileira de Ciências Sociais, vol. 13, nº 38.

MATOS, Maria Izilda S. de. Cabelo, barba e bigode: masculinidades, corpos e subjetividades. Locus: revista de história, Juiz de Fora, v. 17, n.02, 2011.

MIHAELY, Gil. Um fio de diferença: masculinidade no mundo do trabalho, 1870-1910. Anos 90, Porto Alegre, v. 14, n. 25, p.17-35, jul. 2007.

NORONHA, Fabrícia Rúbia Guimarães de Souza. Tradição e modernidade: o perdão na cultura jurídica luso-brasileira. In: SIMPÓSIO NACIONAL DE HISTÓRIA, 23, 2005, Londrina. Anais do XXIII Simpósio Nacional de História - História: guerra e paz. Londrina: ANPUH, 2005.

POMPEU, Thomaz. Juízo histórico do senador Pompeu sobre factos do Ceará. Revista do Instituto do Ceará, ano IX, 1895, p. 5-54.

SILVA, Cristina Nogueira da. Conceitos oitocentistas de cidadania: liberalismo e igualdade. Análise Social, vol. XLIV (192), 2009, p. 533-563. 
SILVA, Luiz Geraldo. Gênese das milícias de pardos e pretos na América Portuguesa: Pernambuco e Minas Gerais, séculos XVII e XVIII. Revista de História, São Paulo, no 169, p. 118. Disponível em: <http://www.scielo.br/pdf/rh/n169/0034-8309-rh-16900111.pdf>.

SOUZA, Adriana Barreto de. A governança da justiça militar entre Lisboa e o Rio de Janeiro (1750-1820). Almanack. Guarulhos, n. 10, agosto de 2015, p. 388-408.

WEHILING, Arno; WEHLING, Maria José. Exército, milícias e ordenanças na Corte Joanina: permanências e modificações. Da Cultura. Ano VIII, n. 14, jun. 2008, p. 2632. Disponível em: 〈http://www.funceb.org.br/images/revista/5_2q0t.pdf〉.

\section{Capítulos de livros}

BERBEL, Márcia Regina. Os apelos nacionais nas Cortes de Lisboa (1821/1822). In: MALERBA, Jurandir (Org.). A independência brasileira: novas dimensões. Rio de Janeiro: Editora FGV, 2006, p. 181-207.

BERBEL, Márcia; FERREIRA, Paula Botafogo C. Soberanias em questão: apropriações portuguesas sobre um debate iniciado em Cádis. In: BERBEL, Márcia; OLIVEIRA, Cecília Helena de Salles (Orgs.). A experiência constitucional de Cádis. São Paulo: Alameda, 2012, p. 169-199.

BICALHO, Maria Fernanda Baptista. O que significava ser cidadão nos tempos coloniais. In: ABREU, Martha; SOIHET, Rachel (Orgs.). Ensino de história: conceitos, temáticas e metodologia. Rio de Janeiro: Casa da Palavra, 2003, p. 139-151.

CALERO, Manuel Chust. As Cortes de Cádis, a Constituição de 1812 e sua transcendência americana. In: BERBEL, Márcia; OLIVEIRA, Cecília Helena de Salles (Orgs.). A experiência constitucional de Cádis. São Paulo: Alameda, 2012, p. 11-29.

FURET, François. Antigo Regime. In: FURET, François; OZOUF, Mona. Dicionário Crítico da Revolução Francesa. Rio de Janeiro: Ed. Nova Fronteira, 1989, p. 621-632.

HESPANHA, António Manuel; XAVIER, Ângela Barreto. A representação da sociedade e do Poder. In: HESPANHA, António Manuel (Coord.). História de Portugal: Antigo Regime. Lisboa: Editorial Estampa, 1993, p. 121-155. 
HESPANHA, António Manuel. Da “iusticia” à “disciplina”. Textos, poder e política penal no Antigo Regime. In: HESPANHA, António Manuel (Org.). Justiça e litigiosidade: história e prospectiva. Lisboa: FCG, 1993.

JANCSÓ, István; PIMENTA, João Paulo. Peças de um mosaico (ou apontamentos para o estudo da emergência da identidade nacional brasileira). In: MOTA, Carlos Guilherme. Viagem Incompleta. São Paulo: SENAC, 2000.

KLEIN, Herbert. A participação política no Brasil do século XIX: os votantes de São Paulo em 1880. In: Dados - Revista de Ciências Sociais, vol. 38, n 3, 1995, p. 527544.

KOSELLECK, Reinhart. Espaço de experiência e horizonte de expectativa. In: Futuro passado. Rio de Janeiro: PUC/Rio, 2006, p. 305-327.

LOPES, José Reinaldo de Lima. A constituição moderna. In: BERBEL, Márcia; OLIVEIRA, Cecília Helena de Salles (Orgs.). A experiência constitucional de Cádis. São Paulo: Alameda, 2012, p. 285-309.

LOPES, José Reinaldo de Lima. Iluminismo e jusnaturalismo no ideário dos juristas da primeira metade do século XIX. In: JANCSÓ, István. Brasil: formação do Estado e da Nação. São Paulo: Hucitec, 2003, p. 195-218.

LOPES, José Reinado de Lima; SLEMIAN, Andrea. nA justiça na criação dos Estados ibero-americanos. Experiência comparada Argentina - Brasil - México. In: FONSECA, Ricardo Marcelo (Org.). As formas do Direito. Curitiba: Juruá Editora, 2013.

LYNCH, Christian Edward Cyril. A vocação sociológica do legislador: o pensamento político do Marquês de Caravelas. In: RIBEIRO, Gladys Sabina (Org.). Brasileiros e Cidadãos. São Paulo: Alameda, 2008, p. 149-173.

MAXWELL, Kenneth. Por que o Brasil foi diferente? O contexto da independência. In: MOTA, Carlos Guilherme. Viagem Incompleta. São Paulo: SENAC, 2000.

MERQUIOR, José Guilherme. O repensamento da Revolução. In: FURET, François; OZOUF, Mona. Dicionário Crítico da Revolução Francesa. Rio de Janeiro: Ed. Nova Fronteira, 1989, p. XVII-LVII. 
MATTOS, H. A Escravidão Moderna nos Quadros do Império Português: o Antigo Regime em perspectiva atlântica. In: FRAGOSO, João Luís; BICALHO, Maria Fernanda; GOUVÊA, Maria de Fátima. (Orgs.). O Antigo Regime nos Trópicos. A Dinâmica Imperial Portuguesa (séculos XVI-XVIII). Rio de Janeiro: Civilização Brasileira, 2001, v. 1, p. 141-162.

MENDES, Fábio Faria. Encargos, privilégios e direitos: o recrutamento militar no Brasil nos séculos XVIII e XIX. In: CASTRO, Celso; IZECKSOHN, Vitor; KRAAY, Hendrik (Orgs). Nova História Militar Brasileira. Rio de Janeiro: Editora FGV, 2004.

NEVES, Lúcia Maria Bastos Pereira das. Estado e política na independência. In: GRINBERG, Keila; SALLES, Ricardo. O Brasil Imperial, vol. I. Rio de Janeiro: Civilização Brasileira, 2009.

Os panfletos políticos e a cultura política da independência do Brasil. In: JANCSÓ, Istvan. Independência: história e historiografia. São Paulo: Hucitec: 2005.

; NEVES, Guilherme Pereira das. Constitución Brasil. In: SEBASTIÁN, Javier Fernández. (Org.). Diccionário politico y social del mundo iberoamericano. La era de las revoluciones, 1750-1850. Iberconceptos I. Madrid: Fundación Carolina/Sociedad Estatal de Commemoraciones Culturales / CEPC, 2009, v. 1, p. 337-351.

OLIVEIRA, Cecília Helena de Salles. A Carta de 1824 e o poder do monarca: memórias e controvérsias em torno da construção do governo constitucional no Brasil. In: BERBEL, Márcia; OLIVEIRA, Cecília Helena de Salles (Orgs.). A experiência constitucional de Cádis. São Paulo: Alameda, 2012, p. 219-250.

OZOUF, Mona. Revolução. In: FURET, François; OZOUF, Mona. Dicionário Crítico da Revolução Francesa. Rio de Janeiro: Ed. Nova Fronteira, 1989, p. 840-851.

PAMPLONA, Marco Antonio Villela. Nación - Brasil. In: SEBASTIÁN, Javier Fernández; LOMNÉ, Georges. (Orgs.). Diccionario politico y social del mundo iberoamericano. Iberconceptos - II. .Madrid: Universidade del País Vasco y Centro de Estudios Políticos y Constitucionales - Min de la Presidencia, 2014, v. 2, p. 882-893.

RIBEIRO, Gladys Sabina; PEREIRA, Vantuil. O I Reinado em Revisão. In: GRINBERG, Keila; SALLES, Ricardo. O Brasil imperial, vol. I. Rio de Janeiro: Civilização Brasileira, 2009. 
GRINBERG, Keila. O fiador dos brasileiros. Rio de Janeiro: Civilização Brasileira, 2002.

SANTOS, Beatriz Catão; FERREIRA, Bernardo. Ciudadano - Brasil. In: SEBASTIÁN, Javier Fernández; LOMNÉ, Georges. (Orgs.). Diccionario politico y social del mundo iberoamericano. Iberconceptos - II. .Madrid: Universidade del País Vasco y Centro de Estudios Políticos y Constitucionales - Min de la Presidencia, 2014, v. 2, p. 211-222.

SANTOS, Mírian. Norma Jurídica: uma questão de linguagem. Veredas - Rev. Est Ling., Juiz de Fora, v. 9, n.1 e n.2, p. 107-121, jan./dez., 2005, p. 107-121.

SLEMIAN, Andrea. A administração da justiça como um problema: de Cádis aos primórdios do Império do Brasil. In: BERBEL, Márcia; OLIVEIRA, Cecília Helena de Salles (Orgs.). A experiência constitucional de Cádis. São Paulo: Alameda, 2012, p. 251-283.

Seriam todos Cidadãos? In: JANCSÓ, István. Independência: história e historiografia. São Paulo: Hucitec, 2005, p. 829-880.

À nação independente, um novo ordenamento jurídico: a criação dos Códigos Criminal e do Processo Penal na primeira década do Império do Brasil. In: RIBEIRO, Gladys Sabina (Org.). Brasileiros e cidadãos. São Paulo: Alameda, 2008, p. 175-206.

\section{Livros}

ARAÚJO, Carlos Eduardo Moreira de. Cárceres imperiais: a Casa de Correção do Rio de Janeiro. Seus detentos e o sistema prisional no Império, 1831-1861. Unicamp: Tese de doutorado, 2009.

ARAUJO, Valdei Lopes de. A experiência do tempo: Conceitos e Narrativas na Formação Nacional Brasileira (1813-1845). São Paulo: Hucitec, 2008.

BARMAN, Roderick. Brazil: the forging of a nation. Stanford: Stanford University press, 2003.

BAJER, Paula. Processo Penal e Cidadania. Rio de Janeiro: Jorge Zahar Editor, 2002.

BECCARIA, Cesare. Dos delitos e das penas. São Paulo: Edipro, 2015. 
BENTHAM, Jeremy. Teoria das penas legais. São Paulo: Edições Cultura, 1943.

. O Panóptico. Belo Horizonte: Autêntica Editora, 2008.

BERBEL, Márcia Regina. A nação como artefato: Deputados do Brasil nas Cortes Portuguesas. São Paulo: Hucitec, 2010.

BUESCU, Mircea. 300 anos de inflação. Rio de Janeiro: Apec, 1973.

CARNEIRO, David. História da Guerra Cisplatina. Brasília: Universidade de Brasília, 1983.

CARREIRA, Liberato de Castro. História financeira e Orçamentária do Império do Brasil, 2 tomos. Brasília: Senado Federal, 1980.

CARVALHO, José Murilo de. Cidadania no Brasil: o longo caminho. Rio de Janeiro: Civilização Brasileira, 2001.

. A construção da Ordem: a elite política imperial. Teatro de sombras: a política imperial. Rio de Janeiro: Civilização Brasileira, 2010.

CARVALHO, José Murilo de; CAMPOS, Adriana Pereira (Orgs.). Perspectivas da cidadania no Império. Rio de Janeiro: Civilização Brasileira: 2001.

CASTRO, Celso. A invenção do Exército. Rio de Janeiro: Jorge Zahar Editor, 2002.

CAVALCANTI, Amaro. O meio circulante nacional. Brasília: Editora Universidade de Brasília, 1983.

COSTA, Fernando Dores. Insubmissão. Dissertação de doutoramento: Universidade Nova de Lisboa, 2006.

DIAS, Maria Odila L. da Silva. A interiorização da metrópole e outros estudos. São Paulo: Alameda, 2005.

DOHLNIKOFF, Miriam. O Pacto Imperial. São Paulo: Globo, 2005.

DONGHI, Túlio Halperin. História da América Latina. São Paulo: Editora Paz e Terra, 2011.

DORATIOTO, Francisco M. General Osório: a espada liberal do Império. São Paulo: Companhia das Letras, 2008. 
. Maldita Guerra. São Paulo: Companhia das Letras, 2002.

FRANCO, Afonso Arinos de Melo. Um Soldado do Reino e do Império. Rio de Janeiro: Biblioteca do Exército Editora, 1942.

FREYRE, Gilberto. Modos de homem \& modas de mulher. Rio de Janeiro: Record, 1987.

GRINBERG, Keila; SALLES, Ricardo. O Brasil Imperial, vol. I. Rio de Janeiro: Civilização Brasileira, 2009.

JANCSÓ, István (org). Brasil: formação do Estado e da Nação. São Paulo: Hucitec, 2003.

Independência: história e historiografia. São Paulo: Hucitec, 2005.

KIRSCHNER, Tereza Cristina. José da Silva Lisboa, Visconde de Cairu: itinerários de um ilustrado luso-brasileiro. São Paulo: Alameda; Belo Horizonte: PUC-Minas, 2009.

KRAAY, Hendrik. Política racial, Estado e forças armadas na época da independência: Bahia, 1790-1850. São Paulo: Hucitec, 2011.

LIMA, Oliveira. O movimento de independência. Rio de Janeiro: Topbooks, 1997.

LOPES, José Reinaldo de Lima. O Direito na História: lições introdutórias. São Paulo: Atlas, 2011.

As palavras e a lei. São Paulo: Editora FGV, 2004.

LYRA, Maria Lourdes Viana. A utopia do Poderoso Império. Rio de Janeiro: Sette Letras, 1994.

MATTOS, Hebe Maria. Escravidão e Cidadania no Brasil monárquico. Rio de Janeiro: Jorge Zahar Editor, 2000.

MATTOS, Ilmar Rohloff. O tempo saquarema. Rio de Janeiro: Access, 1994.

MCBETH, Michal Charles. The politicians vs. the generals: the decline of the Brazilian army during the First Empire, 1822-1831. Doctoral Dissertation. University of Washington, 1972. 
MENDES, Fábio Faria. Recrutamento militar e construção do Estado no Brasil Imperial. Belo Horizonte: Argvmentvm, 2010.

NEVES, Lúcia Maria Bastos Pereira das. Corcundas e constitucionais. Rio de Janeiro: Revan: FAPERJ, 2003.

PRADO JR. Caio. Evolução política do Brasil e outros estudos. São Paulo: Brasiliense, 1979.

PEREIRA, Vantuil. Ao Soberano Congresso. São Paulo: Alameda, 2010.

POCOCK, John. Linguagens do ideário político. São Paulo: Editora da Universidade de São Paulo, 2013.

RÉMOND, René. O século XIX. São Paulo: Editora Cultrix, 1990.

RODRIGUES, José Honório. Independência: revolução e contra-revolução. Rio de Janeiro: Biblioteca do Exército Editora, 2002.

RODRIGUES, Neuma Brilhante. Nos caminhos do Império: a trajetória de Raimundo José da Cunha Mattos. Tese de Doutorado: Universidade de Brasília, 2008.

SAES, Décio. A formação do Estado burguês no Brasil (1888-1889). Rio de Janeiro: Paz e Terra, 1985.

SALLES, Ricardo. Guerra do Paraguai: escravidão e cidadania na formação do exército. Rio de Janeiro: Paz e Terra, 1990.

SANTOS, Amilcar Salgado dos. A Guerra entre o Brasil e a República Argentina em 1827. São Paulo: Escolas Profissionaes do Lyceu Coração de Jesus, 1923.

SCHWARTZ, Robert. Ao vencedor as batatas. São Paulo: Duas Cidades, 1977.

SLEMIAN, Andrea. Sob o Império das Leis. São Paulo: Hucitec, 2009.

SOUZA, Adriana Barreto de. O exército na consolidação do Império: um estudo histórico sobre a política militar conservadora. Rio de Janeiro: Arquivo Nacional, 1999. Duque de Caxias. Rio de Janeiro: Civilização Brasileira, 2008.

SOUZA, Iara Lis Carvalho de. Pátria Coroada: O Brasil como Corpo político autônomo. São Paulo: Unesp, 1999. 
SZMRECSÁNYI, Tamás; LAPA, José R. do A. (orgs.). História econômica da Independência e do Império. São Paulo: Hucitec, 1996.

URICOECHEA, Fernando. O minotauro imperial. Rio de Janeiro: Difel, 1978.

VASQUEZ, Eliane Leal. Ciência Penitenciária no Brasil Império: Disciplinar para construir a imagem da nação civilizada. PUC-SP: Tese de doutorado, 2013.

WIEDERSPAHN, H. Oscar. Campanha de Ituzaingó. Rio de Janeiro: Biblioteca do Exército Editora, 1961. 